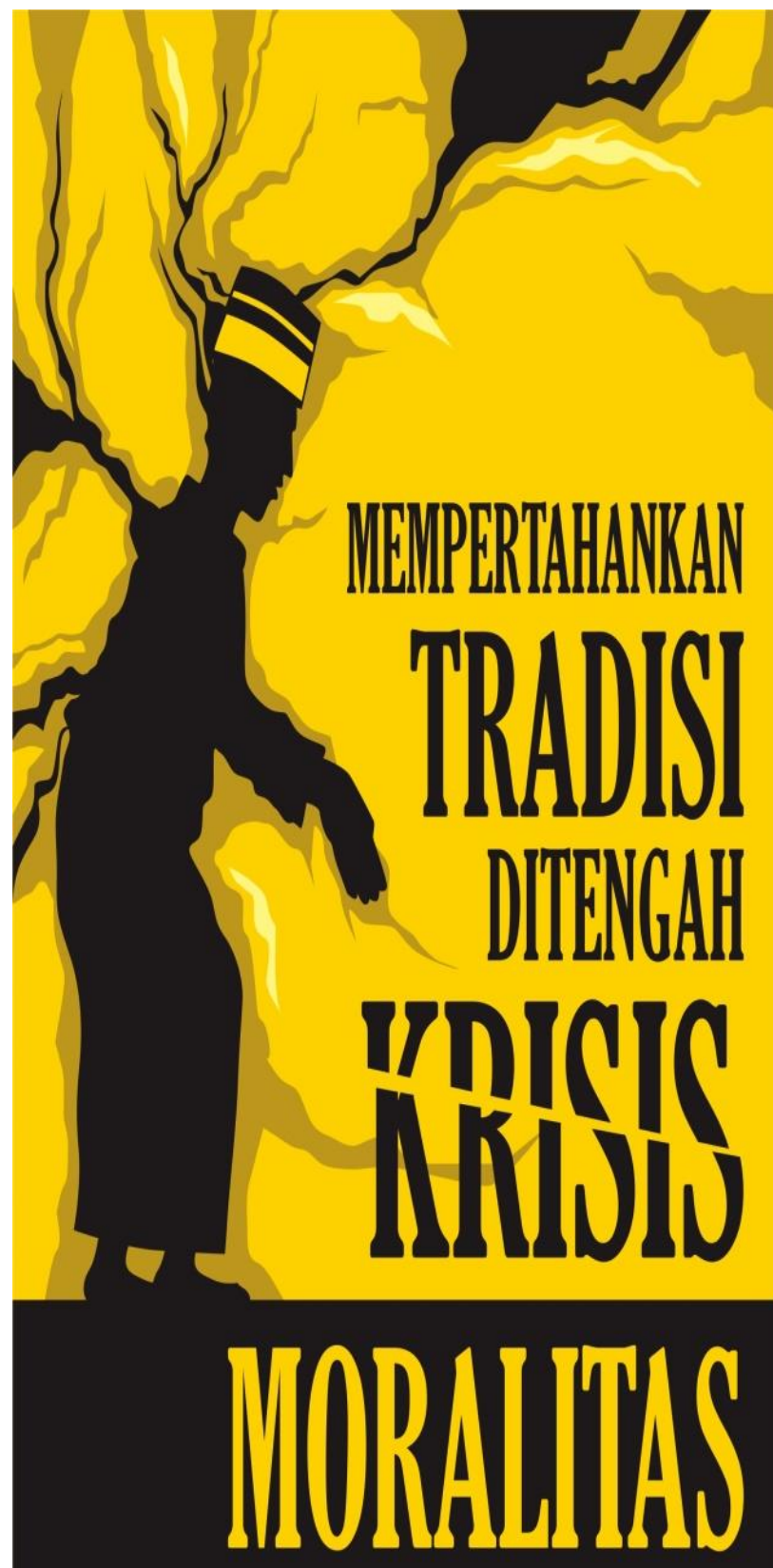

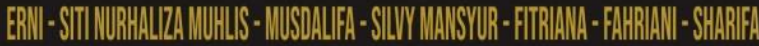

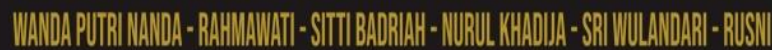

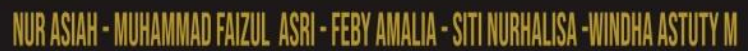

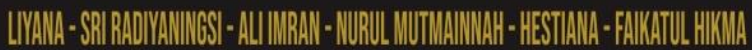
ASHAR - ANDU RAUL SANAPATI-ZULFWKAR ANWDATAMA HAERUL
Riset Budaya

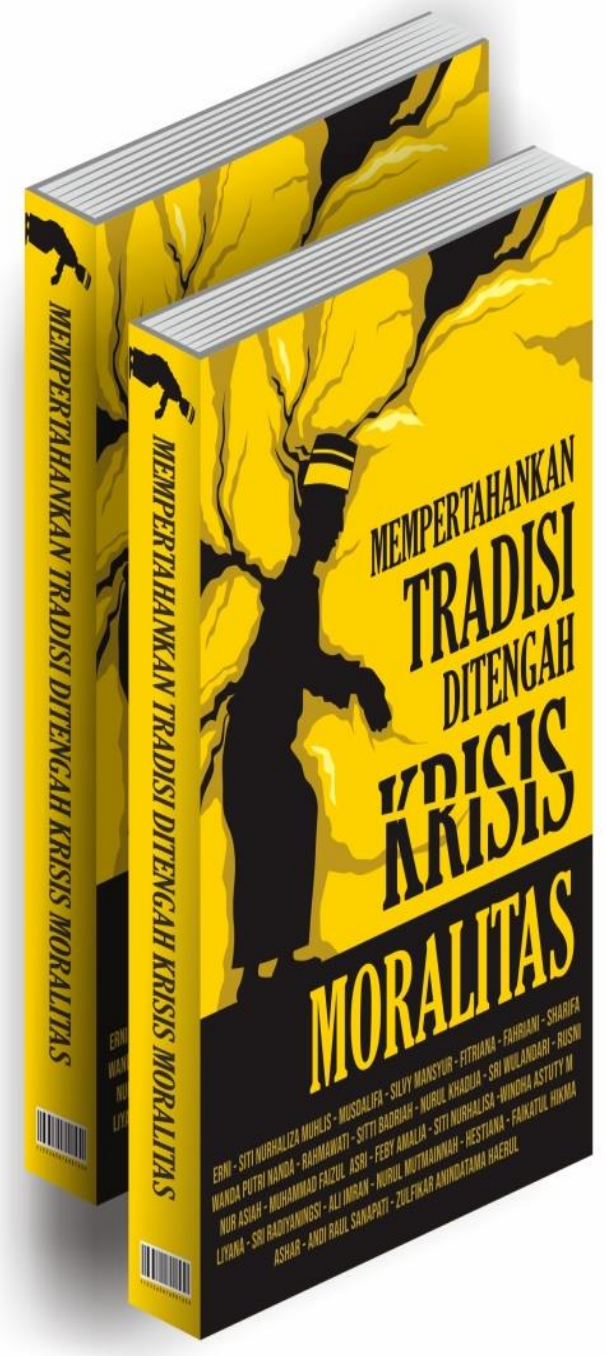


Mahasiswa Jurnalistik Islam 


\section{Riset Budaya: Mempertahankan Tradisi di Tengah Krisis Moralitas}


Sanksi Pelanggaran Pasal 113

Undang-Undang Nomor 28 Tahun 2014

tentang Hak Cipta

(1) Setiap orang yang dengan tanpa hak melakukan pelanggaran hak ekonomi sebagaimana dimaksud dalam Pasal 9 ayat (1) huruf i untuk Penggunaan Secara Komersial dipidana dengan pidana penjara paling lama 1 (satu) tahun dan/atau pidana denda paling banyak banyak Rp.100.000.000 (seratus juta rupiah).

(2) Setiap Orang yang dengan tanpa hak dan/atau tanpa izin Pencipta atau pemegang Hak Cipta melakukan pelanggaran hak ekonomi Pencipta sebagaimana dimaksud dalam Pasal 9 ayat (1) huruf c, huruf d, huruf f, dan/atau huruf $h$ untuk Penggunaan Secara Komersial dipidana dengan pidana penjara paling lama 3 (tiga) tahun dan/atau pidana denda paling banyak Rp.500.000.000 (lima ratus juta rupiah).

(3) Setiap Orang yang dengan tanpa hak dan/atau tanpa izin Pencipta atau pemegang Hak Cipta melakukan pelanggaran hak ekonomi Pencipta sebagaimana dimaksud dalam Pasal 9 ayat (1) huruf $a$, huruf b, huruf e, dan/atau huruf g untuk Penggunaan Secara Komersial dipidana dengan pidana penjara paling lama 4 (empat) tahun dan/atau pidana denda paling banyak Rp.1.000.000.000 (satu miliar rupiah).

(4) Setiap Orang yang memenuhi unsur sebagaimana dimaksud pada ayat (3) yang dilakukan dalam bentuk pembajakan, dipidana dengan pidana penjara paling lama 10 (sepuluh) tahun dan/atau pidana denda paling banyak Rp.4.000.000.000 (empat miliar rupiah) 


\section{Riset Budaya Mempertahankan Tradisi di Tengah Krisis Moralitas}

Editor : Dr.Muhammad Qadaruddin Abdullah,M.Sos.I

\section{Penulis:}

Erni - Siti Nurhaliza Muhlis - Musdalifa - Silvi Mansyur - Fitriana Fahriani - Wanda Putri - Rahmawati - Sitti Badriah - Nurul Khadija Sri Wulandari - Rusni - Nur Asiah - Muhammad Faizul Asri - Feby Amalia - Siti Nurhalisa - Windha Astuty M - Sharifa - Liyana - Sri radiyaningsi - Ali Imran - Nurul Mutmainnah B - Hestiana - Faikatul Hikma - Ashar - Andi Raul Sanapati - Zulfikar Anindatama Haerul

\section{IAIN PAREPARE NUSANTARA PRESS}

Penerbit: IAIN Parepare Nusantara Press 


\section{Riset Budaya:}

Mempertahankan Tradisi di Tengah Krisis Moralitas

Editor: Dr.Muhammad Qadaruddin,M.Sos.I

ISBN: 978-623-93262-4-1

Penata Letak: Siti Nurhalizah Muhlis

Desain Sampul: Muh. Iqbal

Copyright (CMuhammad Qadaruddin, 2020

iiiv+ $169 \mathrm{hlm} 17 \times 25 \mathrm{~cm}$

Cetakan I, April 2020

Diterbitkan oleh

\section{IAIN Parepare Nusantara Press}

Jalan Amal Bhakti Soreang, Parepare, Sulawesi Selatan

E-mail. nusantarapress@iainpare.ac.id

Hak cipta dilindungi undang-undang

Dilarang memperbanyak karya tulis ini dalam bentuk dan dengan cara apapun tanpa izin tertulis dari penerbit.

Dicetak oleh IAIN Parepare Nusantara Press, Parepare

Isi di luar tanggung jawab percetakan 


\section{KATA PENGANTAR}

Alhamdulillah, segala puji bagi Allah Swt atas segala rahmat, hidayah dan inayahNya sehingga buku yang berjudul Riset Budaya: Mempertahanan Tradisi di Tengah Krisis Moralitas ini dapat diterbitkan. Selawat dan salam tercurah kepada Nabi Muhammad Saw yang telah menjadi rahmatan lilalamin dan uswatun hasanah.

Buku ini merupaan karya mahasiswa jurnalistik pada mata kuliah studi budaya lokal, oleh karena itu proses penyelesaian buku ini tidak terlepas dari eseriusan mahaiswa jurnalistik Islam dalam perkuliahan. Buku ini diterbitkan dengan menggunakan anggaran pengusulan ISBN perguruan tinggi IAIN Parepare Nusantara Press.

Oleh karena itu, penghargaan setinggi-tingginya dan ucapan terima kasih yang sedalam-dalamnya, kami ucapkan kepada semua pihak yang telah membantu dalam proses penulisan buku ini. Buku ini yang merupakan kumpulan tulisan mahasiswa Jurnalistik Islam semester 4 angkatan 2018 yang merupakan angkatan kedua program studi Jurnalistik Islam.

Semoga tahun-tahun selanjutnya mahasiswa program studi Jurnalistik Islam dapat meningkatkan karyanya, kami ucapkan selamat atas terbitnya buku kedua mahasiswa Jurnalistik Islam dan kami sangat bangga terhadap mahasiswa Jurnalistik Islam yang senantiasa berkarya melalui tulisan. Akhirnya, kami berharap masukan dan kritik dari pembaca, karena jika dalam buku ini masih ada kekurangan, penulis adalah manusia biasa yang tidak lepas dari kekeliruan 


\section{Daftar Jsi : \\ Kata Pengantar \\ Daftar isi}

Acara Adat Mangongnggo Durian Etnis "Pattae"

Sri Radiyaningsi Salmah

Hal. 2-9

\section{Budaya Rambu Solo}

Musdalifah

Hal. 10-14

\section{Tradisi Pernikahan adat Bugis Tolotang}

Nurul Mutmainnah B

Hal. 15-18

Mapasullung Bobo

Liyana

Hal. 19-23

Tradisi Mappatettong Bola

Windha Astuty M

Hal. 24-3 1

Tradisi Perkawinan Bugis Desa Letta

Erni

Hal. 32-35

Mappanre Temme

Nur Asiah

Hal. 36-41

Tradisi "ma'baca baca"

Zulfikar Anindatama Haerul

Hal. 42-46

Paradoksal Dialek Bugis Bone dan Bugis Sidenreng

Rappang(Sidrap) di Sulawesi Selatan

Siti Nurhaliza Muhlis'

Hal. 47-53 


\section{Budaya Uang Panai \\ Rahmawati \\ Hal. 54-58}

Budaya Pakkacaping Tommuane Mandar Fahriani

Hal. 59-67

\section{Walasuji Dalam Pernikahan Adat Bugis}

Muhammad Ali Imran Syafril

Hal. 68-73

Suku Bugis Surganya Pamali

Rusni

Hal. 74-80

Budaya Mappatabe' Di Kalangan Masyarakat

Sri Wulandari

Hal. 81-85

Tradisi Mappadendang Suku Bugis

Fitriana

Hal. 86-92

Warisan Budaya Maccera Manurung Di Desa Kaluppini Kab.

Enrekang

Muhammad Faizul Asri

Hal.93-98

Budaya Mahpalili

Sharifa

Hal. 99-103

Ciri Khas Baju Bodo (Tokko) Adat Bugis Yang Terletak Di Sulawesi Selatan Indonesia

Nurul Khadijah

Hal. 104-108

Makna Musik Bambu (Bas) Pada Masyarakat

Desa Tongko Enrekang

Siti Nurhalisa

Hal. 109-116 


\section{Mappasoro Sasi Budaya Mandar Lero}

Ashar

Hal. 117-122

Tradisi Mappattuada

Hestiana

Hal. 123-129

Tradisi Sayyang Pattuddu di Masyarakat Suku Mandar

Feby Amalia

Hal. 130-134

Menre' Bola

Faikatul Hikmah

Hal. 135-140

Mappasikkarawa dalam Sudut Pandang Islam

Wanda Putri

Hal. 141-148

Tradisi Barazanji pada masyarakat Parepare di Kecematan

Bacukiki Kelurahan Lompoe"

Sitti Badriah

Hal. 149-157

Sigajang Laleng Lipa

Andi Raul Sanapati

Hal. 158-161

Tradisi Mappano Masyrakat Bugis

Silvi Mansyur

Hal. 162-165 
Riset Budaya 



\section{Riset Budaya}




\section{Acara Adat Mangongnggo Durian Etnis "Pattae"}

Tradisi masyarakat tumbuh dan berkembang sesuai dengan lingkungan sosialnya. Tradisi Pattae adalah kebiasaan yang telah tumbuh dan menjadi identitas diri suatu aktivitas komunitas masyarakat yang mengandung unsur keagamaan. Karena itu tradisi masyarakat sangat dipengaruhi oleh lingkungan sosial, budaya, dan agama. Bahkan agama sangat menentukan tatanan tradisi itu sendiri.

Tradisi masyarakat dengan cirinya tumbuh dan berkembang secara turun temurun, biasanya tidak disertai aturan-aturan tertulis yang baku, namun wujudnya dalam bentuk lisan, perilaku, dan kebiasaan tetap terjaga. Berbagai bentuk tradisi telah menjadi kajian para sosiolog dan antropolog sehingga mengundang interpretasi pemikiran bahwa setiap kelompok masyarakat memiliki tradisi kepercayaan tersendiri dimana tradisi tersebut diyakini kebenarannya secara turun-temurun dari generasi ke generasi.

Tak dapat disangkal bahwa masih banyak masyarakat yang masih mempertahankan tradisi tersebut hingga dewasa ini disebut sebagai masyarakat tradisional karena bentuk kepercayaan mereka masih bersifat "animisme dan dinamisme." Animisme menurut Koentjaraningrat adalah kepercayaan yang menganggap bahwa semua yang bergerak dianggap hidup dan mempunyai kekuatan ghaib atau memiliki roh yang berwatak baik maupun buruk.

Sedangkan dinamisme dalam Ensiklopedia Umum diartikan sebagai kepercayaan keagamaan primitif pada zaman sebelum datangnya agama Hindu ke Indonesia. Primitif adalah suatu kebudayaan dimana terdapat individu-individu tertentu yang belum mengenal dunia luar. Seperti yang kita ketahui dalam tradisi mangongnggo". Masyarakat tradisi Pattae, biasanya dilakukan saat musim buah tiba. Pada tradisi tersebut, Masing-masing warga mengumpulkan hasil panen buah yang berkualitas. 
Kebudayaan merupakan warisan yang tak ternilai harganya bagi bangsa ini. Kebudayaan itu harus kita lestarikan, dijaga, dan dimanfaatkan. Wulandari menjelaskan bahwa kebudayaan mengandung dua kemampuan sekaligus, yaitu kemampuan untuk melestarikan dan kemampuan untuk mengembangkan. Kemampuan mempertahankan kebudayaan agar keberadaannya tetap lestari, dan kemampuan mengambangkan kebudayaan agar lebih berkembang dan lebih maju meskipun adanya perubahan zaman. Kemampuan tersebut akan sangat bergantung pada tingkat ketahanan budaya masyarakatnya. Semakin rendah ketahanan masyarakat, semakin kuat budaya luar mempengaruhi dan bahkan menghilangkannya secara perlahan-lahan.

Kebudayaan Indonesia dari zaman ke zaman selalu mengalami perubahan. Perubahan ini terjadi karena faktor masyarakat yang memang mengiginkan perubahan kebudayaan, atau karena masuknya unsur-unsur globalisasi ke dalam kebudayaan Indonesia. Dampak positif adanya globalisasi antara lain kemampuan teknologi yang saat ini telah memberi kemudahan pada setiap orang untuk berkomunikasi. Adapun dampak negatif globalisasi seperti nilai-nilai budaya Indonesia saat ini telah terpengaruh dengan budaya barat. Hal ini sangat berdampak kepada pola kehidupan manusia, misalnya tata cara berpakaian, sopan santun, pergaulan yang bebas, minuman terlarang, akan tetapi saat ini kepedulian masyarakat terhadap kebudayaan daerah mulai luntur.

Suku pattae adalah sebuah etnis yang yang berasal dari Prov. Sulawesi Barat, tepatnya di Kab. Polewali Mandar. Sebagian besar suku Pattae bermukim di Kec. Matakali hingga perbatasan Kab. Pinrang. Mayoritas suku Pattae memleuk agama Islam. Itu dapat kita lihat dari tradisi-tradisi mereka yang bernuansa Islami. Pada umumnya suku pattae bermata pencaharian sebagai petani padi, jagung, hasil buah-buahan jika sudah masuk musimnya, dan sebagainya. Sebagian juga ada yang berkebun kopi, dan sayurmayur.

Suku pattae memiliki tradisi yang disebut dengan mangongnggo durian yang dilaksanakan sekali setahun jika sudah masuk musim buah. Tradisi ini sudah dilakukan warga Desa Batetangnga Kec. Binuang, Kab. Polewali Mandar. Sejak lama dan ini 
merupakan warisan nenek moyang terdahulu, untuk itu seharusnya kita menjaga warisan budaya-budaya yang masih ada.

Dalam pelaksanaan acara tersebut biasanya diumumkan di masjid. Setelah pengumuman itu, masyarakat secara berbondongbondong membawa hasil panennya di tempat yang telah ditentukan oleh penanggung jawab wilayah masing-masing. Menurut masyarakat setempat "durian tidak bisa dibawa pulang, melainkan dimakan di tempat". Biasanya dalam acara mangongnggo buah durian ini, panitia pelaksana biasa mengumpulkan hasil panen dari masyarakat sebanyak 3000 buah meskipun mereka ada target yang harus ditempuh dalam acara adat tersebut. Menurut mereka "semua masyarakat yang akan datang di acara adat tersebut bisa mencicipi kenikmatan durian dari desa betetangnga", kata masyarakatn setempat.

Mangongnggo durian ini juga merupakan alat pemersatu bagi masyarakat untuk saling memahami dan tidak membeda-bedakan. Karena kita berkumpul dalam acara adat ini, masyarakat banyak yang datang melalui informasi dari media sosial. Banyak masyarakat dari luar daerah datang hanya untuk mau melihat nilai budaya yang dikembangkan di desa batetangnga tersebut, tidak hanya melihat tapi terkadang mereka juga ikut menimati makanan buah tersebut.

Tradisi "Mangngonggo" ini tidak berlaku bagi semua masyarakat Pattae. Hal ini hanya diberlakukan untuk masyarakat yang mendapat rezeki berupa buah-buahan disetiap musim buah tiba, itu pun tidak ada paksaan. Karena kegiatan ini telah mendarah daging atau sudah menjadi tradisi turun temurun masyarakat suku Pattae.

Kegiatan "mangngonggo" pun terus dilakukan untuk menjaga dan melestarikan nilai-nilai adat suku Pattae. Begitulah penjelasan singkat tentang adanya tradisi "onggo" atau "mangngonggo"yang berkaitan dengan musim buah-buahan. Jadi, mari kita menikmati dan mensyukuri karunia Tuhan yang telah diberikan di atas tanah Pattae yang Mala'biq.

Pernyataan Parson mengenai teori fungsionalisme struktural yang membahas tentang struktur-struktur masyarakat dan hubungan mereka satu sama lain. Struktur-struktur itu dilihat saling mendukung 
dan cenderung ke arah keseimbangan dinamis. Penekanannya terletak pada cara pemeliharaan tatanan antara berbagai unsur masyarakat. Parson tidak hanya memikirkan sistem sosial dalam dirinya tetapi juga hubungan-hubungannya dengan sistem-sistem tindakan lainnya, khususnya sistem budaya dan kepribadian.

Akan tetapi pandangan dasarnya mengenai hubunganhubungan intersistemik yang sama dengan pandangan mengenai relasi-relasi intrasistematik, yakni mereka didefinisikan oleh kohesi, consensus, dan ketertiban. Dengan kata lain, struktur-struktur sosial yang beraneka ragam melaksanakan berbagai fungsi positif untuk satu sama lain.

Dalam setiap masyarakat memiliki kepercayaan lokal yang merupakan tradisi turun temurun dan dilestarikan dari generasi ke generasi. Salah satu bagian dari kepercayaan yang ada di masyarakat yaitu tradisi "mangongnggo durian" yang ada di Desa kanang Mandar, Kecamatan Binuang, Kabupaten Polewali Mandar. Ini merupakan tradisi tahunan masyarakat sebagai bagian rasa syukur mereka terhadap hasil panen yang didapatkan pada saat menjelang musim buah-buahan tiba. Tujuan dari tradisi ini sematamata untuk menjaga tradisi yang sudah menjadi turun-temurun dari masyarakat suku pattae menjaga dan melestarikan nilai-nilai, adatadat suku pattae.

Selama beberapa dasawarsa yang lalu, teori strukturalfungsionalisme telah merajai kajian Antropologi dan sosiologi di dunia barat, sehingga Kingsley Davis berani mengatakan bahwa struktural fungsionalisme adalah sama dan sebangun dengan antropologi dan sosiologi. Di inggris teori ini mencapai puncak pencapaiannya dalam dasawarsa 1930 dan 1950, dalam masa mana struktural fungsionalisme dikatakan sebagai identik dengan British Social Antropology. Pelopornya yang terkenal di sana adalah Radcliffe-Brown (R-B) dan Malinowski. Teori ini di Amerika mencapai puncak kejayaannya pada tahun-1950-an, ketika Talcott Parsons mengembangkannya dalam bentuk yang lebih canggih dan kompleks di Departement of Social Relation, Harverd University.

Dari sejarahnya sendiri, Struktural Fungsionalisme lahir sebagai reaksi terhadap teori evolusionari. Jika tujuan dari kajiankajian evolusionari adalah untuk membangun tingkat-tingkat 
perkembangan budaya manusia, maka tujuan dari kajian-kajian struktural-fungsionalisme adalah untuk membangun suatu sistem sosial, untuk struktur sosial, melalui pengajian terhadap pola hubungan yang berfungsi antara individu-individu, antara kelompokkelompok, atau antara institusi-institusi sosial dalam suatu masyarakat, pada suatu kurun masa tertentu.

Jadi pendekatan evolusionari lebih bersifat historis dan diaknoris, sedangkan pendekatan struktural fungsional lebih bersifat statis dan sinkronis. Struktural fungsional adalah pengabungan dari dua pendekatan, yang bermula dari pendekatan fungsional Durkheim, kemudian digabungkan dengan pendekatan struktural RB. Karena itu untuk memahami pendekatan struktural fungsional, orang harus melihat dulu sejarah perkembangan pendekatan fungsional (journal.ui.ac.id)

Oleh karena itu kegiatan mangngonggo durian merupakan kegiatan yang sifatnya terstrutur yang dilakukan oleh masyarakat bersama pemerintah, sebagai bentuk rasa syukur dan merajut kebersamaan antar masyarakat.

Menurut masyarakat setempat "acara yang diwariskan secara turun-temurun ini diperkenalkan oleh Etnis Pattae di kab.polewalimandar (polman). Mangngonggo durian ini dalam bahasa pattae berarti menahan durian. Maksudnya ialah acara yang dilaksanakan tiap tahun inidikemas dalam bentuk makan buah durian secara gratis".

Dalam acara adat ini biasa kita berpacu dengan kondisi buah durian yang ada, karena tidak selamanya dilaksanakan jika kondisi hasil panen buah kurang bagus atau kadang pula tak ada sama sekali, tutur narasumber. Mangongnggo durian ini adalah salah satu adat istiadat yang dilakukan sebagai rasa perwujudan ,rasa syukur kepada atas hasil panen buah yang melimpah. Nenek moyang kita terdahulu ini melaksanakan acara adat ini atas rasa syukur melimpahnya buah durian, langsat, dan rambutan.

Pada acara adat ini petani menyumbangkan hasil kebun seikhlasnya. Petani tidak ditargetkan berapa banyak yang akan dibawa untuk hasil panen buah mereka dalam rangka acara mangongnggo durian tiba, karena mangongnggo durian ini 
merupakan alat pemersatu bagi masyarakat untuk saling memahami dan tidak membeda-bedakan. Karena kita berkumpul dalam acara adat ini, masyarakat banyak yang datang dari luar Desa Batetangnga. Hanya untuk melihat kebudayaan yang dikembangkan dalam "suku pattae"

Tradisi adalah adat atau kebiasaan turun temurun dari nenek moyang yang masih dijalankan dalam masyarakatnya. Di Desa Batetangnga salah satu tradisi yang masih dilaksanakan sampai sekarang ini adalah mangongnggo durian. Tradisi ini mempunyai arti penting yang terkandung nilai-nilai tersendiri dipahami oleh masyarakat itu sendiri. Yang dimana tradisi ini wajib dilakukan dan masih dipertahankan sampai sekarang oleh masyarakat Etnis Pattae.

Berdasarkan hasil wawancara yang dilakukan mengenai "acara adat mangongnggo durian etnis Pattae". Dapat kita ketahui bahwa fenomena budaya yang terjadi di masyarakat di Desa Batetangnga saat ini terkait upacara adat mangongnggo durian/makan buah durian secara gratis. Menunjukkan sebagian besar masyarakat masih melestariakan warisan budaya nenek moyang, dari itu kita harus menjaga budaya-budaya kita yang masih terjaga kelestariannya.

Walaupun dunia semakin canggih kita tidak boleh melupakan warisan dari nenek moyang kita. Sebagai generasi yang cemerlang kita dianjurkan untuk tetap mempertahanan warisan-warisan acara adat yang masih ada. Untuk diperkenalkan ke dunia luar agar orangorang di luar sana yang belum mengenal adat-adat kita bisa mengenalnya dengan memperkenalkan budaya-budaya yang masih terjaga oleh orang tua kita.

Sebagai masyarakat hendaknya kita tetap menjaga baik kebudayaan serta nilai-nilai luhur dalam khasanah kebudayaan polewali mandar, namun sebagai masyarakat yang beragama Islam masyarakat hendaknya mampu memilih mana yang tidak sesuai dengan ajaran Islam (sulbarkita.com)

Tradisi ini merupakan juga bagian dari unsur kebudayaan yang pelaksanaan yang mempunyai makna yang penting dalam masyarakat Desa Batetangnga. Dimana dalam perayaan tradisi ini merupakan salah satu bentuk acara adat yang dilaksanakan untuk 
memberikan rasa syukur masyarakat etnis pattae atas limpahan rezeki yang diberi kepada hasil panen buah-buahan.

Untuk mempertahanan tradisi ada beberapa hal yang harus dilakukan. Pertama masyarakat pasti memiliki ciri khas tradisi yang melembaga dalam ritualitas kehidupan sehari-hari. Ciri-ciri tersebut telah menjadi identitas yang hendaknya harus kita hormati sebagai wujud pergulatan rasionalitas bagi para penganut yang meyakini tradisi tersebut dalam wujud rasa syukur mereka dalam melaksanakan acara tradisi mangongnggo durian. Kedua kita harus tetap menjaga, melestraikan tradisi-tradisi seperti ini agar bisa dikenal bukan hanya dari dalam saja tetapi orang dari luar pun bisa mengetahui tradisi-tradisi kita sendiri.

Kita juga tidak boleh terlalu cepat menilai negatif sesuatu dalam suatu tradisi adat yang dilaksanakan oleh masyarakat setempat. Dalam tradisi harus kita saling menghargai dan melihat makna, nilai-nilai yang terkandung di dalamnya. seperti tradisi mangongnggo durian salah satunya, kita melihat bagaimana masyarakat etnis pattae melaksanakan acara tersebut dengan penuh kenikmatan dan dari situ juga mereka bisa berbagi dalam pelaksanaan acara adat mangongnggo durian ini yang dilaksankan hanya setahun sekali, ketika musim buah-buahan tiba.

Dalam pelaksanaan acara tradisi ini, kita diajarkan juga bagaimana mensyukuri rezeki atas hasil panen yang kita dapat setiap tahunnya, karena mengapa acara tradisi mangognggo durian ini kan merupakan perwujudan rasa syukur yang sudah dilakukan sejak lama dan merupakan warisan dari nenek moyang Etnis Pattae di Desa Batetangnga. 


\section{Biodata Penulis}

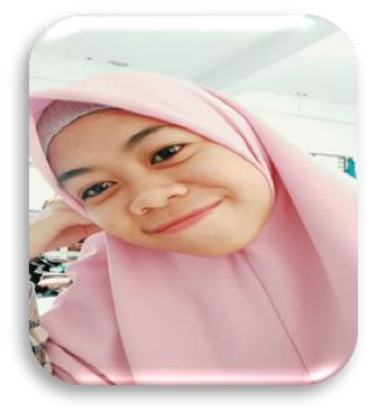

Sri Radiyaningsi Salmah Tempat, Tgl, kanang (Polman), 29/july/1999 Nama Orang Tua H. Abd Salam (alm) dan Hj. Mahadiah Pendiddikan formal TK RA (RaudatulAtfal) Kanang 2005. SDN 012 Kanang 2012. Mts DDI Pacongang (pinrang) 2014. MAN (Madrasah Aliyah Negeri Pinrang) 2017 Perguruan Tinggi IAIN (institut agama Islam negeri pare-pare) Fakultas FUAD (ushuluddin adab dan dakwah) Jurusan/Prodi Jurnalistik Islam

\section{Motto Hidup:}

"Sukses Adalah Berani Bertindak Dan Punya Prinsip" 


\section{Budaya Rambu Solo}

Suku toraja yang berada di Sulawesi selatan. Suku ini adalah suku yang terbilang unik dibanding suku-suku lain yang ada di Indonesia. Kebudayaan asli yang masih dimiliki suku ini menjadi daya tarik para wisatawan. Karena suku ini memiliki ciri khas tersendiri yang dapat dibilang cukup langka dan unik. (www.academia.edu) Suku toraja terkenal akan ritual pemakaman suku toraja merupakan peristiwa sosial yang penting, biasanya dihadiri oleh ratusan orang dan berlangsung selama beberapa hari. Suku roraja adalah suku yang menetap di pegunungan bagian dari utara Sulawesi-Selatan, Indonesia.

Mayoritas suku Toraja memeluk agama Kristen, sementara sebagian menganut Islam dan kepercayan anisme yang terkenal sebagai aluk to dolo. Pemerintah Indonesia telah mengakui kepercayaan ini sebagai bagian dari Agama Hindu Dharma, dan ada banyak aluk to dolo salah satunya Budaya "Rambu Solo". Tana Toraja mempunyai upacara adat yang biasa dilakukan, yakni Rambu Solo (upacara kematian). Kenapa harus melaksankan upacara rambu solo ini? karena Upacara Rambu Solo merupakan sebuah upacara pemakaman. (susiangraeni28.blogspot.com)

Pada Upacara Rambu Solo, penduduk Toraja percaya tanpa adanya upacara ritual ini maka arwah orang yang telah meninggal akan memberikan kesialan bagi keluarga yang ditinggalkan. Upacara pemakaman Rambu Solo adalah serangkaian kegiatan yang rumit terkait ikatan adat dan tradisi setempat serta memerlukan biaya yang tidak sedikit. Persiapannya pun hingga berbulan-bulan. Selagi menunggu kesiapan upacara, jasad tersebut dibungkus menggunakan kain yang kemudian disimpan di dalam rumah leluhur atau tongkonan.

Pada upacara kematian ini apa yang menjadi simbol atau alat, serta bagaimana perilaku masyarakat? simbol-simbol sangat penting salah satunya adalah penggunaan simbol kerbau sebagai syarat utama dalam upacara kematian rambu solo. Kerbau di kehidupan masyarakat tana toraja merupakan hewan yang sangat tinggi 
maknanya dan dianggap suci, juga melambangkan tingkat kemakmuran seorang jika memilikinya karena harga satu ekor jutaan sampai ratusan juta rupiah. Upacara pemotongan ini adalah salah satu tradisi khas Tana Toraja dengan cara Ma'Tinggoro (menebas leher) kerbau dalam sekali ayunan menggunakan sebilah parang.

Nama toraja berasal dari bahasa bugis, yaitu "to riaja" yang mempunyai arti orang yang berdiam di negeri atas. Pada saat itu Indonesia di kuasai oleh belanda pada tahun 1909, colonial belanda menyebut suku ini suku toraja. Suku ini terkenal dengan ritual pemakamannya. Selain itu suku ini juga di kenal dengan ukiran kayunya dan rumah adat yaitu tongkonan. Suku toraja terbilang sangat cukup unik, mempunyai banyak ritual salah satunya adalah rambu solo (upacara kematian). Negara ini memiliki kakayaan budaya yang sangat melimpah. Selain itu di Indonesia juga terdapat suku bangsa yang begitu beragam. Salah satunya adalah suku tana toraja yang berada di selawesi suku ini adalah suku yang terbilang unik dibanding suku-suku lain yang ada di Indonesia (www.romadecade.org)

Suku ini memiliki ciri khas tersendiri yang dapat dibilang cukup langka dan unik. Nuansa mistik yang melekat pada suku ini menjadi ciri khas yang membedakan suku ini dengan suku yang lain. Suku ini adalah suku yang penduduknya menetap di pegunungan bagian utara provensi sulawesi selatan. Penduduk suku ini mayoritas penduduk Kristen dan sebagian penduduknya beragama Islam.

Rambu solo adalah upacara kematian yang berarti asap yang arahnya ke bawa. Asap yang arahnya ke bawa artinya ritus-ritus persembahan (asap). Untuk orang mati di laksanakan sesudah pukul 12 ketika matahari mulai bergerak menurun. Rambu solo sering juga disebut Alukard rate matamu' ritus-ritus di sebelah barat. Oleh karena itu ritus-ritus persembahan dilaksanakan di sebelah barat tongkonan rumah, adat toraja. Apakah dalam melakukan upcara ini kita menggunakan undangan? tidak ada undangan khusus bagi orang-orang yang akan menghadiri ritus ini. Setiap masyarakat toraja menyadari bahwa mereka bagian masyarakat tana toraja, dan nilai-nilai dapat dihayati secara benar dan eksistensial oleh orang toraja (wkipedia.org) 
Karena rambu solo adalah bagian yang integral dengan sistem kepercayaan masyarakat toraja kuno yang disebut aluk todolo. Dalam melakukan ritual ini, biasanya menunggu sampai bermingguminggu, berbulan-bulan, bahkan bertahun-tahun sejak hari kematian. Sementara menunggu upacara siap, tubuh orang yang meninggal dibungkus kain dan disimpan di rumah leluhur atau tongkonan. Dalam kepercayaan masyarakat tana toraja (aluk todolo) ada prinsip semakin tinggi tempat jenazah diletakkan maka semakin cepat rohnya untuk sampai ke nirwana.

Salah satu tempat pemakaman di toraja terbilang unik ini menjadi daya tarik tersendiri untuk para wisatawan. Adapun tempat pemakamannya, salah satunya adalah pemakaman dalam goa, pemakaman dalam goa ini disebut londa, londa merupakan tempat makam, yang berletak di atas bukit.

Bagi kalangan bangsawan yang meninggal, keluarga mereka memotong kerbau yang cukup banyak jumlah biasa mencapai 24 sampai 100 ekor, mereka namakan sebagai kurban (ma'tinggoro tedong) salah satu dari kerbau itu namanya kerbau belang (tedong bonga) kerbau ini terbilang cukup mahal. Pada upacara kematian ini penggunaan simbol-simbol sangat penting salah satunya adalah penggunaan simbol kerbau sebagai syarat utama dalam upacara kematian rambu solo.

Kerbau di kehidupan masyarakat tana toraja merupakan hewan yang sangat tinggi maknanya dan dianggap suci, juga melambangkan tingkat kemakmuran seorang jika memilikinya karena harga satu ekor jutaan sampai ratusan juta rupiah. Upacara pemotongan ini adalah salah satu tradisi khas. Tana Toraja dengan cara Ma'Tinggoro (menebas leher) kerbau dalam sekali ayunan menggunakan sebilah parang. (tonenebece.blogspot.com)

Leluhur memiliki pengaruh yang kuat dalam kehidupan orang toraja, dan oleh karena itu leluhur harus dihormati salah satunya dengan menggelar upacara rambu solo.

1. Nilai kekerabatan. Nilai ini tercermin dari ungkapan simpati kerabat yang datang dengan membawa beragam bantuan. Hal ini mereka lakukan untuk menguatkan kekerabatan mereka. 
2. Pelestarian tradisi. Upacara aluk rambu solo merupakan warisan leluhur, dengan menggelar upacara ini merupakan simbol upaya pelestarian tradisi.

3. Menjaga semangat suku pelaksanaan upacara aluk rambu solo juga merupakan salah satu upaya untuk menjaga semangat kesatuan suku karena karena upacara ini menjadi perekat masyarakat toraja.

Adat dan budaya merupakan warisan nusantara yang harus di lestarikan agar tidak punah. Harapan satu-satunya terletak pada generasi mudah suatu daerah. Dan keluarga adalah kelompok sosial dalam politik terutama dalam suku toraja, setiap desa adalah suatu keluarga besar bagi masyarakat toraja. Apakah di suku tana toraja memiliki berbagai macam budaya yang hingga sekarang ini masih di pertahankan? Iya masyarakat tana toraja, masih mempertahankan salah satu budaya ini rambu solo. Rambu solo adalah upacara pemakaman yang berada di tana toraja. upacara ini merupakan adat istiadat yang telah diwarisi oleh masyarakat toraja secara turun temurun hingga saat ini mewajibkan keluarga yang ditinggal mati membuat pesta besar sebagai penghormatan terakhir kepada mediang yang telah pergi.

Upacara rambu solo memiliki nilai-nilai leluhur dalam kehidupan masyarakat, diantaranya adalah gotong royong dan tolong menolong. Unsur tolong menolong pun berperan juga dalam pelaksanaan rambu solo. Upacara ini dilakukan oleh siapapun yang mampu. Penduduk tana toraja hidup di dalam komunitas kecil, dimana mereka yang sudah menikah akan meninggalkan orang tuanya dan membangun kehidupan di tempat lain. Anak tersebut tetap mengikuti garis keturunan orang tua dan mendiami satu rumah adat yang disebut tongkonan, tentu saja mereka tidak lupa dengan adat mereka.

Suku tana toraja percaya bahwa kematian bukanlah sesuatu yang datang dengan tiba-tiba tetapi merupakan sebuah proses yang bertahap menuju dunia arwa atau akhirat dalam masa penungguan itu, jenaza dibungkus dengan beberapa helai kain dan disimpan di dalam tongkonan. 
Biodata Penulis

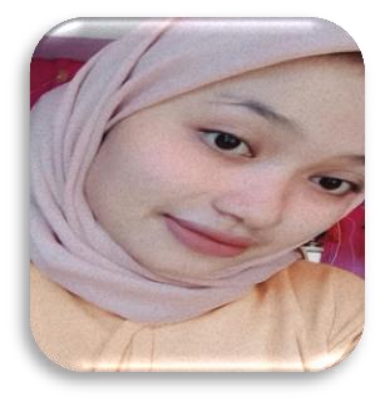

Musdalifah dilahirkan di Enrekang, tepat pada tanggal 02, Oktober, 1999. Pada tahun 2006, saya mulai memasuki bangku sekolah dasar. Saat itu saya bersekolah di MIN Uluway (Madrasah Ibtidaiyah Negeri) uluway, selama 6 tahun lamanya. Setelah itu saya melanjutkan ke jenjang MTS. Tepatnya di, Tsanawiya Roni (MTS) Uluway tepatnya di tana toraja, selama 3 tahun lamanya. Pada tahun ajaran 2015, saya lulus dari MTS tersebut. Setelah saya lulus dari MTS saya melanjutkan kejenjang lebih tinggi lagi yaitu jenjang SMK. Di sini saya melanjutkan sekolah saya di SMK negeri 3 parepare, saya mengambil jurusan Teknik Komputer Dan Jaringan (TKJ). Selama tiga tahun lamanya. Setelah saya lulus dari smk tersebut saya melanjutkan pendidikan saya di salah satu kampus yang berada di kota parepare. Yaitu kampus Institut Agama Islam (IAIN) parepare disini saya mengambil Prodi Jurnalistik Islam pada Fakultas Ushuluddin Adab Dan Dakwah (FUAD). Dan saat ini saya sedang melanjutkan pendidikan saya di institut agama Islam (IAIN) parepare. 


\section{Tradisi Pernikahan adat Bugis Tolotang}

To wani To lotang atau biasa dikenal Tolotang adalah sebuah kepercayaan sebagian Masyarakat Amparita kecematan Tellu Limpoe Kabupaten Sidenreng Rappang mereka biasa menyebutnya Dewata Sewae. Upacara adat pernikahan komunitas tolotang masih terjaga hingga saat ini karena merupakan warisan para leluhur. Pesta adat yang di awali dengan malam mappacci (malam pacar) dihadiri dari pemangku adat, keluarga, kerabat dan undangan terhormat. Prosesi adat pernikahan masyarakat adat Tolotang ini hanya salah satu bagian dari sejumlah adat budaya yang masih tetap dipertahankan ditengah perkembangan arus modernisasi.

Upacara adat pernikahan tolotang masih terjaga dan di pelihara secara turun temurun karena upacara pernikahan ini merupakan warisan para leluhur. Upacara adat pernikahan ini melalui beberapan tahapan, tahapan pertama yaitu "Paddoppo Adeng" ritual ini dimulai dengan acara menumbuk padi dari pagi, para perempuan menumbuk padi hingga semua uwa dan uwatta kumpul. Uwa adalah sebutan untuk tokoh agama di komunitas Tolotang, sedangkan uwatta adalah para pemangku ritual agama lokal itu. Tahapan ini dilaksanakan setelah pihak perempuan menerima pinangan pihak laki-laki.

"Mappaccl" (pacar) Proses ini bertujuan untuk membersihkan dan mensucikan kedua pengantin dari hal-hal yang tidak baik. Dimulai dengan penjemputan kedua mempelai, yang kemudian duduk di pelaminan, itu di depan mereka disusun perlengkapanperlengkapan.

Setelah perlengkapan-perlengkapan tersebut ditaruh, satu persatu Uwa dan uwatta mengusapkan pacci ketelapak tangan pengantin serta mendoakan kepada Tuhan yang maha esa. Bukan hanya mappacci di acara adat pernikahan tolotang juga diadakan mandi kembang dengan istilah bugis dio majeng dengan arti memandikan pengantin perempuan sebelum diadakan mappacci dengan tujuan meminta perlindungan dari dewata sewwae. 
Pernikahan adat bugis juga diadakan mapenre bottin/mengantar Pengantin laki-laki ke rumah pengantin perempuan, mappasikarawa yaitu melakukan sentuhan pertama dimana pengantin laki-laki berperan penting dalam memegang keberhasilan rumah tangga. Mapparola yaitu pengantin perempuan melakukan kunjungan balasan ke rumah pengantin laki-laki dengan iringannya. Setelah diadakan prosesi pernikahan maka pengantin laki-laki dan perempuan serta keluarga melakukan ziarah ke makam leluhur sebagai bentuk penghormmatan dan kesyukuran atas pernikahan yang telah berlangsung.

Prosesi pernikahan masyarakat adat Tolotang adalah tidak adanya tenda tetapi hanya menggunakan rumah panggung serta ditambahi atau diperluas dengan sebutan "sarapo". semua yang hadir duduk bersila di lantai papan rumah panggung itu. Khusus pemangku adat atau tamu kehormatan akan duduk di atas tikar daun lontar yang telah disiapkan tuan rumah. Memberikan pemaknaan bahwa kebersamaan dan kesetaraan pada masyarakat kami itu masih dijunjung tinggi.

"Ciri khas adat kami itu tidak ada satupun kursi di ruang tamu kami hanya ada ranjang "Tempat Tidur" berfungsi sebagai tempat istirahat dan tempat pelaminan jika kami adakan pesta perwakinan, rumah akan ditambah dengan istilah bugis yaitu SARAPO berfungsi untuk tamu mulai dari keluarga, kerabat dan lainnya". Ujar Patadangi Selaku pemangku adat tolotang

Tak heran jika tidak ditemukan kursi satupun di rumah pengantin, yang ada hanya tempat pelaminan yang merupakan tempat tidur yang penuh dengan dekorasi yang terbilang "wah" yang menjadi tempat duduk. Ciri khas dari tamu undangan yang merupakan masyarakat tolotang yaitu dengan Tradisi berpakaian mirip dengan kebanyakan muslim. Laki-lakinya sering bersarung dengan kopiah sebagai penutup kepala. Perempuannya yang sedikit berbeda. Perempuan Tolotang akan mengenakan dua sarung. Satu diikat di pinggang, satunya diselempangkan dan sarung yang diguakan yaitu darung batik yang merupakan sarung ciri khas tolotang. 
Upacara adat pernikahan tolotang masih terjaga dan di pelihara secara turun temurun karena upacara pernikahan ini merupakan warisan para leluhur. Prosesi adat pernikahan masyarakat adat Tolotang ini hanya salah satu bagian dari sejumlah adat budaya yang masih tetap dipertahankan ditengah perkembangan arus modernisasi. Pesta adat yang diawali dengan malam 'mappacci' (pacar), dihadiri para pemangku adat, keluarga, kerabat dan undangan kehormatan.

Sementara yang menjadi ciri khas prosesi pernikahan masyarakat adat Tolotang adalah semua yang hadir duduk bersila di lantai papan rumah panggung itu. Khusus pemangku adat atau tamu kehormatan akan duduk di atas tikar daun lontar yang telah disiapkan tuan rumah. Ini memberikan pemaknaan bahwa kebersamaan dan kesetaraan pada masyarakat kami itu masih dijunjung tinggi. Tak heran jika tidak ditemukan kursi satupun di rumah pengantin, yang ada hanya tempat pelaminan yang merupakan tempat tidur yang penuh dengan dekorasi yang terbilang "wah" yang menjadi tempat duduk pengantin. 
Biodata Penulis

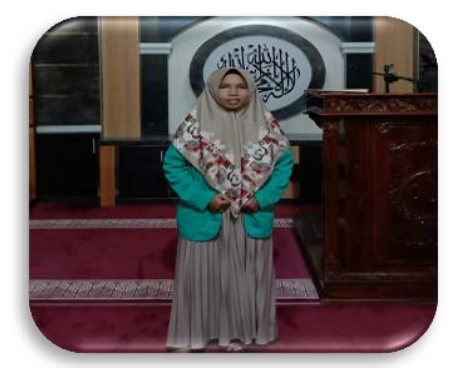

Nama saya Nurul Mutmainnah B, biasanya akrab dipanggil Innah . Saya lahir di Amparita, 03 oktober 1999, Saya anak Bungsu dari tujuh bersaudara, Ayah saya bernama Baharuddin B dan Ibu saya bernama Ramlah. Ayah saya adalah seorang imam kelurahan Baula dan Ibu saya sudah wafat sejak saya umur 1 tahun. Saya tinggal di Amparita Kabupaten sidrap. Menempuh pendidikan TK hingga menegah Atas di kabupaten sidenreng rappang. Tepatnya, MI DDI amparita, Mts DDI Amparita kelas VII hingga kelas VIII dan tamat di Mts Ma'had DDI Pangsid, Dan Madrasah Aliyah DDI Tellu limpoe. Menempuh pendidikan madrasah aliyah DDI tellu limpoe dengan jurusan Ilmu pengetahuan Alam. Saya juga aktif dalam berbagai kegiatan di sekolah dan bergabung dengan osis dan pramuka. Saya pernah melakukan penelitian sejarah di Gua sumpang bita pangkep serta pernah melakukan praktikum kimia menyalakan lampu menggunakan batrai. Setelah saya menyelesaikan pendidikan di tingkat Madrasah aliyah, saya melanjutkan pendidikan di salah satu perguruan tinggi yang berada di kota parepare, pada Prodi Jurnalistik Islam Fakultas Ushuluddin Adab dan Dakwah IAIN parepare, prestasi yaitu Tulisan pernah dimuat di Koran Harian Parepos, Media Online Pijar News serta saya seorang guru mengaji di TK/TPA Ar Rahman Baula Yang terletak di Amparita kecematan tellu limpoe kabupaten sidrap. Pengalaman Organisasi \& KOMUNITAS: LPM RED LINE IAIN PAREPPARE, FATAYATNU KOTA PAREPARE, KOMUNITAS ONE DAY ONE JUZ

Motto : "Teruslah Kreatif dalam menulis jangan pantang menyerah" 


\section{Mapasullung Bobo}

Di Sulawesi-selatan tepatnya di Desa Barugae Kab.pinrang terdapat adat yang dinamakan Mapasullung Bobo ( Syukuran Padi ) yang sampai kini masih dipertahanan oleh warga Desa Barugae. Hampir semua warga Desa Barugae mengadaan Mapasullung Bobo ketika mereka sudah panen. Hal ini merupakan salah satu tanda syukur kepada Allah SWT atas keberhasilan panen yang mereka dapatkan. Memuaskan atau tidak hasil panen yang mereka dapatkan warga Desa Barugae tetap mengadakan mapasullung bobo sebagai tanda syukur mereka.

Pada saat warga Desa Barugae melakukan adat mapasullung bobo, biasanya mereka mengadakan acara ma'baca. Mereka akan mempersiapkan sesajian makanan yang akan dibaca, seperti sokko, ayam, pisang dll. Besar kecil acara yang mereka adakan tergantung dari ekonomi masing-masing warga desa barugae yang ingin megadakan acara Mapasullung Bobo.

Teori ritus dikemukakan oleh rebertson smith dalam koentjaraningrat, sebagai salah satu simbol dari suatu kenyataan didasar atas simbol dari suatu masyarakat yang sangat penting (transcendent) yang merupakan realitas rohani kepada nilai-nilai tertinggi dari suatu komunitas atau masyarakat. Terkait dengan sentuhan dan aktivitas rohani, manusia dalam hal memenuhi segala keinginanya senantiasa menggunakan alam sebagai media pancapainnya.

Adanya anggapan-anggapan mengenai alam sebagai sumber kehidupan yang mampu mempengaruhi dan menciptakan prosesproses yang berlangsung dalam alam raya. Guna memenuhi berbagai maksud tertentu manusia mempergunakan teknik-teknik atau caracara serta segenap pengetahuan dan kekuasaan, baik kekuasaan yang ada di luar dirinya. Sehingga manusia dan segenap kekuasaanya mampu mempergunakan alam sebagai media dan juga untuk mengubah alam sesuai kebutuhan. Dalam kamus besar bahasa Indonesia (www.artikata.com,diakses 29 mei 2013), Ritus ini berarti tata cara dalam upacara keagamaan. Hal ini sangat bersesuaian 
dengan kenyataan yang ada dimana ritus biasa digunakan dalam suatu upacara keagamaan tertentu.

Robertson Smith dalam koenjaningrat mengemukakan tiga gagasan penting yang menambah pengertian tentang ritus sebagai sistem upacara keagamaan ini, diantaranya: Gagasan pertama, mengenai soal bahwa di samping sistem keyakinan dan doktrin, sistem upacara merupakan suatu perwujudan religi atau agama yang memerlukan studi dan analisis yang khusus. Dalam agama upacara itu tetap, tapi latar belakang ,keyakinan, maksud atau doktrinnya berubah.

Gagasan ke dua adalah bahwa upacara religi atau agama yang bersangkutan bersama-sama mempunyai fungsi sosial untuk mengintensifkan solidaritas masyarakat. Para pemeluk suatu agama menjalankan upacara dengan sungguh-sunguh, dan ada yang mejalankannya setengah-setengah. Mereka menganggap upacara adalah untuk mengalami kepuasan keagamaan secara pribadi dan upacara adalah kewajiban sosial.

Gagasan ke tiga adalah teori mengenai fungsi upacara sesaji. Dalam upacara seperti itu, manusia menyajikan seekor binatang terutama darahnya, kepada dewa, kemudian memakan sendiri sisa daging dan darahnya. Karena teori ritus itu sendiri berkaitan erat dengan sebuah ritual, dalam konteks teori ini.

Dhavamony membedakannya menjadi empat macam yakni: Tindakan magic, yakni tindakan yang dikaitkan dengan penggunaan bahan-bahan yang bekerja karena daya-daya mistis. Tindakan religius, Kultus para leluhur juga bekerja dengan cara ini. Ritual konsitutif, yang mengungkapkan atau mengubah hubungan sosial dengan merujuk pada pengertian-pengertian mistik dengan demikian upacara-upacara kehidupan menjadi khas.

Dalam penelitian mengenai Mapasullung Bobo (Syukuran Padi) di Desa Barugar Kec. Duampanua Kab. Pinrang ini saya telah mewawancarai salah satu masyarakat yang juga melakukan acara Mapasullung Bobo, yaitu Ibu Mariani.

Acara mapasullung bobo dilakukan oleh masyarakat Desa Barugae setiap kali mereka selesai panen sebagai tanda syukur terhadap yang Maha yang kuasa. Biasanya masyarakat melakukan 
acara ini di rumah masing-masing. Sebelum Masyarakat melakukan acara atau adat mapasullung bobo terlebih dahulu masyarakat mempersiapkan sesajian makanan yang akan di baca dan di makan oleh tamu-tamu nantinya.

Tradisi ini adalah sesuatu yang telah dilakukan sejak lama dan menjadi bagian dari kehidupan sekelompok masyarakat. Tradisi mapasullung bobo di Desa Barugae ini sudah muncul sejak lama dan menjadi kebiasaan yang teratur oleh masyarakat. Yang menjadi masalah masyarakat adalah mereka akan bersaing saing pada saat melakukan acara, jadi yang ekonominya rendah akan tersiksa dengan keinginanya sendiri yang mau mengadakan acara yang besabesar seperti tetangga-tetangga yang lain.

Melihat kenyataan tersebut, Sebagian masyarakat pun melakukan upaya-upaya untuk menanggulangi permasalahpermasalahn yang ada. Karena jika hal tersebut dibiarkan, tentulah akan merusak system yang ada dalam masyarakat. Dalam hal ini aparatur desa sebagai pelaksana pemerintah melakukan upayaupaya penanggulangan.

Aparatur desa barugae sendiri telah melakukan upaya-upaya penanggulangan yang berupa menasehati masyarakat agar tidak saling bersaing saingan dan mengadakan acara dengan kemampuan mereka masing-masing. Karena melakukan Acara mapasullung bobo tidak harus bermewah-mewah, dengan cara sederhanapun bisa dilakukan.

Menurut salah satu masyarakat desa Barugae faktor yang melatar belakangi munculnya adat mapasulung bobo di Desa Barugae Kec. Duampanua Kab. Pinrang yaitu dari turun temurun nenek moyang mereka dan akan tetap dipertahankan oleh keturunan-keturunan mereka nantinya.

Acara Mapasullung Bobo dilakukan sekali setelah selesai panen, dan dilakukan di rumah masing-masing dengan menyiapkan sesajian untuk dibaca dan dikonsumsi tamu-tamu. Acara mapasullung bobo ini dilakukan karena turun temurun dari nenek moyang dan akan tetap dipertahanan.

Adapun makna mapasullung bobo tersebut bagi masyarakat Desa Barugae adalah rasa syukur terhadap Tuhan atas berkah dan limpahan rezeki berupa padi yang telah mereka panen. Selain itu 
bagi masyarakat Desa Barugae acara mapasullung bobo tersebut adalah doa kepada Tuhan agar panen yang akan datang bisa lebih baik lagi dan dapat berkumpul kembali kedalam acara mapasullung bobo.

Untuk mempertahankan budaya mapasullung bobo yang ada di Desa Barugae ini, Masyarakat akan terus melakukan adat ini dan juga mengajarkan kepada anak-anaknya atau cucu-cucu mereka agar budaya ini tetap terjaga dan masih dipertahanan oleh masyarakat setempat 
Biodata Penulis

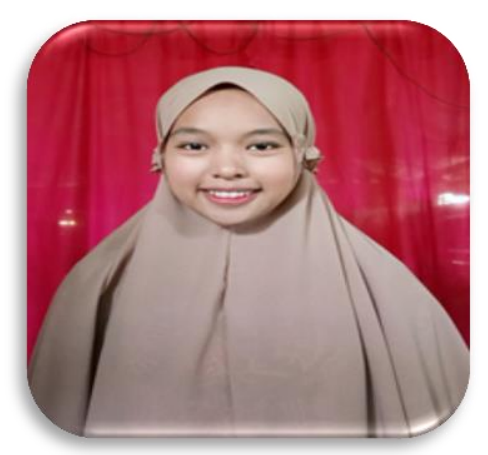

Liyana Tempat/tgl lahir Saluone,12 Mei 199 Pendidikan SDN 134 Data SMPN 2 Duampanua. SMK Negri 5 Pinrang Pergurun Tinggi Institut Agama Islam Negri Pare-Pare

Motto Hidup

"Tetap Berusaha dan Berdo'a" 


\section{Tradisi Mappatettong Bola}

Kemampuan mendirikan rumah pada setiap daerah memiliki aturan dan tata cara yang berbeda. Proses mendirikan rumah panggung sangat disakralkan karena akan disertai dengan upacara atau tradisi tradisional yang melibatkan pemilik rumah dan Panrita/Sanro Bola (ahli rumah Bugis), Panre Bola (tukang) keluarga dan bahkan tetangga. Makna dari ritual ini sesuai dengan kepercayaan tradisional Bugis, rumah dipandang sebagai pusat siklus kehidupan manusia. Tempat manusia dilahirkan, dibesarkan, menikah dan meninggal. Karena itu, ia dipandang sakral dan diperlakukan dengan sangat hormat, agar ia dapat memberi kedamaian, kesehatan, keselamatan, kesejahteraan dan kehormatan bagi penghuninya. (Shima, 2006).

Dalam masyarakat Bugis, terdapat tiga tahap proses untuk memiliki sebuah rumah, pertama yaitu, melaksanakan pekerjaan artinya mengerjakan elemen rumah seperti alliri (tiang), pattolo (pasak), paddinring (dinding) hingga addeng (tangga) dan pettang (lantai kayu), pengawasannyapun tidak terlepas dari panrita bola (ahli rumah). Kedua yakni, proses mendirikan rumah atau mappatettong bola dan terakhir setelah mendirikan rumah yaitu menre' bola baru (naik/masuk rumah baru).

Bentuk struktur rumah tradisional Bugis didominasi oleh tiang (alliri) dan pasak (pattolo) yang saling terhubung satu sama lain sehingga dapat dipasang dan dibongkar kembali serta dapat digeser dan dipindah-tempatkan dengan cara gotong royong. Tradisi gotong royong memiliki dampak sosial kemasyarakatan yakni adanya keinginan untuk saling menolong dan membantu satu sama lain sehingga pekerjaan yang berat akan terasa ringan.

Mendirikan rumah panggung Bugis tidak lepas dari upacara ritual yang pemaknaannya memberi dampak bagi para penghuninya serta menimbulan rasa kebersamaan terhadap masyarakat sekitarnya. "Tau monrie, biasa nallupai makkada, sininna ipigau e engka manang artinna, de'na pada idi tau riolo e. Tau e makkukue assala jadi bawammi, de'na pikkiriki kada engka mo ga deceng 
napoleang pele ri gau." (Generasi saat ini, kadang melupakan bahwa segala sesuatu yang dikerjakan selalu memiliki makna ataupun arti tertentu, tidak seperti kami orang-orang terdahulu. Orang-orang yang sekarang lebih pada ketidak pedulian dan mengerjakan semuanya secara cepat atau asal jadi tanpa memikirkan apakah ada kebaikan yang diperoleh dari pekerjaan tersebut (Wawancara Saharia)

Tradisi adalah sesuatu kebiasaan yang berkembang di masyarakat, baik yang menjadi adat kebiasaan, atau yang diasimilasikan dengan ritual adat atau agama. Atau dalam pengertian yang lain, sesuatu yang telah dilakukan untuk sejak lama dan menjadi bagian dari kehidupan suatu kelompok masyarakat, biasanya dari suatu negara, kebudayaan, waktu, atau agama yang sama. Biasanya tradisi ini berlaku secara turun-temurun baik melalui informasi lisan berupa cerita, atau informasi tulisan berupa kitabkitab kuno atau juga yang terdapat pada catatan prasasti-prasasti.

Tradisi merupakan sebuah persoalan dan yang lebih penting lagi adalah bagaimana tradisi tersebut terbentuk. Menurut Funk dan Wagnalls seperti yang dikutip oleh Muhaimin tentang istilah tradisi dimaknai sebagai pengetahuan, doktrin, kebiasaan, praktek dan lainlain yang dipahami sebagai pengetahuan yang telah diwariskan secara turun temurun termasuk cara penyampaian doktrin dan praktek tersebut. (Muhaimin AG: 2001)

Salah satu tradisi yang hingga saat ini masih setia dipertahankan oleh masyarakat Sulawesi Selatan khususnya Suku Bugis adalah upacara mendirikan rumah. Upacara yang terkenal dengan tradisi gotong royongnya itu masih sangat melekat dan terus dilakukan demi menjaga dan mempererat tali silaturahim antara sesama warga.

Mendirikan rumah atau dalam masyarakat Bugis dikenal dengan sebutan Mappatettong Bola. Mappatettong Bola adalah salah satu upacara ritual yang diwariskan secara turun temurun oleh nenek moyang yang dipercaya dalam suatu kelompok masyarakat. Upacara Mappatettong Bola juga dirangkaikan dengan upacara Menre' Bola Baru (naik rumah baru) yang dilaksanakan setelah proses konstruksi selesai. 
Rumah Adat Bugis adalah rumah panggung kayu. Rumah panggung kayu khas Bugis mengacu pada anutan kepercayaan bahwa alam semesta ini terdiri atas 3 bagian. Itulah sebabnya rumah tradisional Bugis Makassar juga terdiri atas tiga bagian, yaitu; pertama, Rakkeang (reka), atau bagian atap rumah yang dahulu biasanya digunakan untuk menyimpan padi yang telah dipanen. Kedua. Ale Bola (ael bol), yaitu bagian tengah rumah possi' bola (posi bol), dan yang ketiga yaitu yawa bola (yw bol), yaitu bagian bawah rumah (lantai rumah dengan tanah). (Mattulada: 1972)

Begitu penting nilai-nilai yang terkandung dalam upacara ritual Mappatettong Bola, hal ini dibuktikan dalam setiap setiap prosesnya yang selalu memiliki makna, seperti pada saat memilih dan menebang pohon yang cocok untuk membuat alliri (tiang) sebagai penyangga rumah. Selain itu, memilih hari yang baik untuk mulai bekerja serta menetapkan lokasi dan ukuran rumah yang akan dibangun sangat diperhatikan oleh masyarakat terutama bagi si pemilik rumah. Hal tersebut tidak lepas dari upacara ritual yang berisi doa-doa keselamatan dan kesejahteraan bagi para penghuninya.

Makna setiap ritual yang dilakukan dalam proses mappatettong bola ritual sebelum mendirikan rumah. Ritual yang dilakukan sebelum mulai mendirikan rumah yakni mengerjakan setiap elemen atau bagian-bagian rumah yang akan didirikan. Namun, sebelum memulai mengerjakan setiap elemen tersebut, ada ritual yang dilakukan oleh Panrita/Sanro Bola, Panre Bola (tukang rumah) dan pemilik rumah dengan Panrita/Sanro Bola sebagai pemimpin ritual, salah satunya adalah barazanji. Sebelum ritual itu dilaksanakan, maka proses pengerjaan rumah juga tidak boleh dilaksanakan, ini bertujuan agar dalam mengerjakan elemen rumah, tukang rumah akan merasa tenang tanpa ada gangguan.

Prosesi ini memiliki makna "keselamatan." Dengan disertai niat dan doa yang baik dari ritual yang telah dikerjakan, semua pihak yang terlibat dalam proses konstruksi juga pemilik rumah berharap dalam pengerjaan tersebut tidak mendapat kendala. Setelah selesai mengerjakan elemen rumah, tahap selanjutnya adalah mendirikan rumah (Mappatettong Bola), upacara ini dihadiri oleh masyarakat 
setempat hingga keluarga pemilik rumah. Prosesi saat mendirikan rumah ini juga disertai dengan berbagai ritual, salah satunya adalah memanjatkan doa kepada "penjaga rumah" agar diberi keselamatan dan kesehatan pada saat mendirikan rumah.

"mappatettong bola, ada kain kafan, di dalamnya disimpan kitab suci Al-Qur'an, ada juga tumbuhan tebu digantung di pattolo posi bola, tapi ini tebunya tidak diambil daunnya dibiarkan tergerai begitu. Harapannya itu supaya dalam proses mappatettong diberi kemudahan karena selalu melibatkan Tuhan."

Ritual Lise Posi Bola (Isi Pusat Rumah) "bukan cuma di patettong, tiang posi bola juga dikasi isian seperti kaluku (kelapa), tabbu (tebu), loka panasa (Pisang nangka) dan golla cella (gula merah). Maknanya itu supaya dikasiki kebahagian dan keselamatan kalau sudah tinggal di rumah. " (Wawancara Ernawati)

Hal ini dilakukan karena tiang pusat rumah berbeda dengan tiang-tiang yang lainnya. Lise Posi Bola biasanya disimpan dalam kuali tanah atau digantung di pasak rumah dengan menggunakan sarung, lalu Panrita/Sanro Bola akan mengadakan ritual. Makna dari Lise Posi Bola sendiri adalah pengharapan agar penghuni rumah diberi kebahagian serta keamanan.

Setelah semua proses selesai, masyarakat yang ikut membantu dalam mendirikan rumah akan disuguhi makanan oleh pemilik rumah berupa sokko (tepung ketan hitam) dan pallise (makanan yang terbuat dari campuran tepung ketan, kelapa muda dan gula merah).

Nilai Kearifan Lokal dalam prosesi ritual mappatettong bola rumah adalah suatu bangunan yang menjadi tempat atau wadah manusia dalam melangsungkan kehidupan. Bukan hanya sebagai suatu bangunan (arsitektur), melainkan rumah juga sebagai kebutuhan pokok bagi manusia dalam hal berlindung, beristirahat, menikmati hidup, serta sebagai tempat berkumpul keluarga. Rumah sebagai karya arsitektur merupakan pencerminan berbagai aspek manusia, termasuk di dalamnya antara lain: kehidupan sosial, ekonomi, spritual dan budaya. Dengan demikian, rumah diadakan untuk memenuhi kebutuhan untuk menjaga kelangsungan hidup dan kehidupan, mengembangkan kehidupan untuk lebih bermakna dan membuat kehidupan lebih nyaman. (Juhana: 2001) 
Bentuk kerjasama atau gotong royong dalam upacara mappatettong bola menjadi nilai yang paling diperhitungkan. Tanpa adanya rasa saling membantu dalam melakukan pekerjaan yang berat, proses mendirikan rumah tentu tidak akan membuahkan hasil sama sekali. Selain gotong royong, adanya upacara Mappatettong Bola ini juga bisa mempererat tali silaturahim, bukan hanya antar suku Bugis itu sendiri, namun masyarakat dari suku lain bahkan dari agama lain juga turut memberikan kontribusi dalam mendirikan sebuah rumah.

"Selain nilai gotong royong dan mempererat silaturahim, mappatettong bola juga itu salah satu bentuk rasa sukkuru'ta Ri Puang." (Wawancara Abd Rahim)

Barker menjelaskan teori dalam cultural studies, yaitu narasi yang berusaha membedakan dan menjelaskan ciri-ciri umum yang menjabarkan, mendefinisikan dan menjelaskan terus-menerus kejadian yang dipersepsikan. Tetapi teori tidak menggambarkan dunia secara akurat, namun ia adalah alat, instrumen, atau "logika untuk mengintervensi dunia" melalui mekanisme deskripsi, definisi, prediksi, dan kontrol. Dalam cultural studies, teori menempati posisi tinggi, yakni sebagai penunjuk jalan atau peta budaya yang memandu. Teori memandu peneliti cultural studies untuk menceburkan diri ke dalam alam realita untuk dilakukan pembacaanmendalam, dan bertujuan merumuskan teori dan tindakan (praksis) yang bersifat emansipatoris. Dan menilik karakternya sebagaimana telah dideskripsikan di atas, maka cultural studies menggunakan berbagai teori dan konsep untuk menjelaskan dan memahami berbagai realitas sosial kontemporer. Beberapa teori yang dapat digunakan dalam cultural studies sebagaimana dikumpulkan oleh Akhyar Yusuf Lubis dalam buku "Dekonstruksi Epistemologi Modern", diantaranya, adalah:

1. Semiotika (Roland Barthes) Teori ini memahami aspek budaya melalui semiotika, dengan melihat budaya sebagai tanda. Teori ini digunakan dalam penelitian yang bersifat lokal, etnis dan subkultur

2. Habitus (Pierre Bourdieu) Habitus adalah struktur mental atau kognitif, yang digunakan aktor untuk menghadapi kehidupan 
sosial budaya. Atau, dalam pengertian Ritzer, yang dikutip Lubis, habitus adalah konstruksi dunia sosial, struktur sosial yang diinternalisasikan dan diwujudkan. Ia mencerminkan posisi sosial, kebiasaan yang terdapat pada kelas atau kelompok sosial.

3. Teori Industri Budaya (Walter Benyamin) Teori ini memandang industri budaya sebagai produksi mekanis budaya yang disebarluaskan melalui media cetak dan elektronik.

4. Teori Hegemoni (Antonio Gramsci) Teori ini berfokus pada kajian tentang negosiasi penguasa dengan kelompok budaya tandingan menuju landasan budaya dan ideologi yang bisa membuatnya mendapatkan posisi kepemimpinan. Hegemoni adalah upaya bagaimana kelompok penguasa dapat mensubordinasi dan tetap dapat mempertahankan status quo.

5. Teori Pendidikan Kritis (Paulo Freire) Teori ini, yang merupakan cultural studies di bidang pendidikan, mengritik model pendidikan yang disebutnya sebagai bergaya bank. Teori ini berpengaruh besar pada dunia pendidikan (http://diskursusnusantara.blogspot.com)

Teori yang digunakan pada riset ini adalah Teori Semiotika, karena penelitiannya berfokus pada budaya lokal, khusunya di Suku Bugis. Upacara adat Mappatettong Bola merupakan salah satu dari banyaknya upacara adat yang ada di Sulawesi Selatan khususnya Suku Bugis. Upacara ini melibatkan seluruh masyarakat sekitar dalam pelaksanaannya. Ritual yang dipimpin oleh Panrita/Sanro Bola ini memiliki begitu banyak makna dan nilai kearifan lokal apabila dikaji lebih dalam lagi. Setiap prosesi yang dilaksanakan selalu melibatkan Tuhan agar senantiasa dilindungi dan dirahmati baik pada saat sebelum mengerjakan elemen rumah hingga rumah tersebut dihuni. Bentuk gotong royong atau kerja sama merupakan salah satu nilai tertinggi dan paling berharga dalam upacara ini, tak bisa dipungkiri bahwa selain acara mappatettong bola, gotong royong akan selalu menjadi jalan pintas bagi setiap pekerjaan yang yang sulit.

Sebagai salah satu upacara adat yang paling sering dilaksanakan, kiranya dalam mempertahankan nilai kearifan lokal dalam budaya mappatettong bola ini tidaklah begitu sulit. Budaya ini telah dilakukan bertahun-tahun lamanya namun tidak ada satupun 
ritual yang berubah. Nilai gotong royong dalam masyarakat serta eratnya silaturahmi masih menjadi hal yang penting. "Mappatettong bola pasti selalu membutuhkan orang lain, untuk pertahankan itu kita perbaiki saja hubungan dengan orang lain. Kita jalin hubungan baik dengan orang lain."(Wawancara Saharia) 
Biodata Penulis

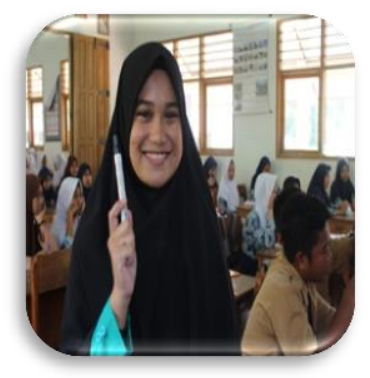

Windha Astuty M, lahir di Pinrang tanggal 07 Oktober tahun 2000. Anak dari dua bersaudara. Penulis lahir dari keluarga sederhana dari pasangan Mursalim (ayah) dan Ernawati (Ibu).

Penulis menempuh pendidikan formal dimulai dari TK Negeri Pembina Pinrang, kemudian SDN 240 Pinrang, lalu melanjutkannya di RSBI SMPN 1 Pinrang dan mengambil jurusan Multimedia saat menempuh pendidikan di SMKN 1 Pinrang hingga akhirnya mampu menempuh pendidikan ke jenjang yang lebih tinggi yakni di Institut Agama Islam Negeri (IAIN) Parepare Fakultas Ushuluddin, Adab \& Dakwah ( FUAD).

Selain itu, penulis juga aktif di Unit Kegiatan Mahasiswa (UKM) Lembaga Pers Mahasiswa (Red Line) sebagai seorang Redaktur berita. Saat ini, penulis masih melanjutkan pendidikannya di Program Studi Jurnalistik Islam semester IV dan ini merupakan karya pertama yang dikerjakan pada mata kuliah Studi Budaya Lokal.

\section{Motto : " Apapun itu, mulailah dari diri sendiri."}




\section{Tradisi Perkawinan Bugis Desa Letta}

Desa letta merupakan salah satu desa di kec. lembang kab. pinrang, yang mayoritas penduduknya beragama Islam. Agama Islam besar pengaruhnya terhadap kehidupan masyarakat setempat, sehingga masyarakat setiap melakukan kegiatan-kegiatan acara ritual termasuk perkawianan, sunatan, selamatan selalu berkaitan dengan keagamaan (Islam) ini menunjukkan bahwa setiap acara yang dilakukan selalu mengundang tokoh agama (kiyai/ustazd), hal yang menarik pada masyarakat setempat adalah tradisi dan budayanya yang sangat kuat, olehnya itu hal ini selalu dikaitkan dengan keagamaan termasuk dalam rangkaian acara perkawinan yaitu mappacci. Hasil wawancara dengan pak haji Nur salah satu tokoh agama setempat mengatakan bahwa:

Mappacci, dalam pengertian masyarakat setempat yaitu membersikan diri, pembersihan ini erat kaitannya dengan hal-hal di luar jangkauan nalar pemikiran, misalnya pengaruh roh-roh jahat. Mappacci merupakan salah satu rangkaian acara pernikahan yang pada umumnya terlaksana satu hari sebelum resepsi pernikahan, dan ini merupakan suatu rangkaian tradisi turun temurun, sehingga masyarakat setempat merasa tidak afdal, lengkap (suk'ku) acaranya kalau tidak dilaksanakan secara tradisi.

Dengan perkembagan penduduk yang semakin padat dibarengi dengan mobilitas penduduk antar daerah sampai ke pelosok desa sehingga tradisi yang kuat dilakukan secara turun temurun keliatannya di desa ini budaya dan tradisi mulai longgar, hal yang terlihat disetiap acara perkawinan, beberapa rangkaian acara sudah tidak dilaksanakan misalnya acara mappacci dan maparolah, namun sebagian masyarakat masih melakukannya. Mencermati hal tersebut di atas menarik untuk dikaji dan ditelusuri dalam suatu karya tulis, sehingga penulis tertarik dengan mengangkat judul" Tradisi pernikahan acara mappacci di desa letta kac. lembang kab. pinrang ". metode penulisan yaitu metode diskriptif dan analisa data 
secara kualitatif, yaitu gambaran deskriftik pergeseran tradisi perkawinan masyarakat setempat.

Mengawali pergeseran nilai tradisi masyarakat setempat yang dipegang teguh secara turun temurun yang dikaitkan dengan mobilisasi masyarakat dari suatu daerah ke daerah lain menujukkan bahwa budaya dan tradisi yang dipegan teguh oleh masyarakat setempat, seakan-akan bergeser dengan masuknya tradisi baru yang dibawah oleh masyarakat pendatang. Menurut Horton (1997 : 225), bahwa, sistem nilai budaya biasanya berfungsi sebagai pedoman tertinggi bagi kelakuan manusia, sistem-sistem tata kelakuan manusia lain yang tingkatnya lebih konkrit, teknologi, mudah mempegaruhi masyarakat setempat. (https://repository.unri.ac.id.)

Kutipan tersebut menunjukan bahwa tradisi setempat secara turun temurun yang sifatnya abstrak dapat terpengaruhi oleh datangnya suatu system tata kelakuan manusia. Dengan pergeseran ini apakah nilai-nilai tradisi masyarakat setempat juga tergeser. Selanjutnya menurut Soerjono (1998: 187) bahwa nilai-nilai budaya ini tidak dapat bergeser atau berubah, karena kebudayaan itu sendiri. Selanjutnya, kutipan tersebut menunjukan bahwa perubahan-perubahan dan penyesuaian-penyesuaian sejalan dengan perkembangan atau kemajuan zaman sehingga harus dilihat sebagai faktor dinamis dalam perubahan unsur kebudayaan, misalnya tentang adat istiadat perkawinan, kesenian dan sebagainya. (https://repository.unri.ac.id.)

Mappacci dalam rangkaian acara perkawinan yang dilaksanakan oleh masyarakat letta adalah suatu adat kebiasaan yang begeser bukan karena kebudayaan akan tetapi disebabkan karna factor ekonomi. Hasil wawancara kepada pak haji Hasan tokoh pemuka agama megemukakan bahwa masyarakat setempat dalam acara ritual perkawinan kadang tidak melakukan acara mappacci jika toh ada masyarakat yang melakukan maka ia salah satu masyarakat yang tingkat perekonomiannya telah mapan, salanjutnya ia katakan bahwa acara mappacci menelan biaya sangat tinggi sehingga sebagian masyarakat hanya melakukan pengajian dan ceramah agama.

Di sisi lain bahwa tidak dilaksanakan acara mappacci pada rangkaian acara pernikahan disebabkan karna factor siri. Hamka 
dalam pandangannya bahwa siri dalam bahasa sul-sel (bugis) bermakna rasa malu (harga diri) dan selanjutnya yang berkaitan dengan iman yaitu siri mate siri dalam arti luas adalah orang yang sudah tidak ada rasa malunya (siri dalam pandangan Hamka dalam www. Google. Com)

Dua hal yang sangat menarik pada rangkain acara mappacci tidak dilaksanaknnya karena factor ekonomi dan factor siri. Siri dalam hal acara mappacci biasanya timbul disebabkan karena keluarga yang dekat dengan hajat perkawinan tidak diundang turut diberikan doa mappacci karena ketentuan tradisi adat hanya sampai tujuh pasang suami istri dan sembilan pasang suami-istri tidak diundangnya sebagian keluarga menyebabkan seakan-akan hubungan kekeluargaan secara emosional dengan keluarga yang tidak diundang seakan-akan terputus karena persoalan harga diri dan siri. Dengan faktor yang berulang ulang dalam tradisi perkawinan maka si pemilik hajat tidak biasanya tidak melakukan acara mappacci.

Pergeseran nilai-nilai budaya dalam perkawinan masyarakat setempat disebabkan unsur-unsur budaya yang dipengaruhi oleh masyarakat pendatang. Tidak dilaksanaknnya acara mappacci dalam rangka acara pernikahan bukan karena nilai-nilai budaya akan tetapi faktor-faktor lain yang menyebabkan antara lain faktor ekonomi, dan unsur siri dalam harga diri

Disarankan bahwa jangan terlalu cepat menilai sesuatu dalam suatu tradisi yang disebabkan perubahan nilai, akan tetapi mari kita melihat dan meninjau lebih dalam suatu kegiatan masyarakat khususnya dalam acara perkawinan.

Factor unsur dalam tradisi masyarakat setempat sangat mudah berubah disebabkan karena pembauran masyarakat setempat dengan masyarakat pendatang, olehnya itu menerima budaya lain, namun kita tetap mempertahankan budaya sendiri, tidak kehilangan identitas. 


\section{Biodata Penulis}

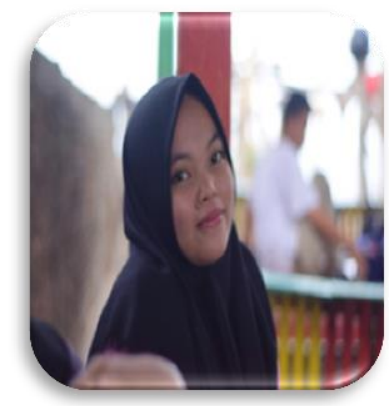

Erni, Tempat/tgl lahir, Mandeangin, 19 oktober 1999 Riwayat pendidikan SDN 152 Lembang. MTS DDI Pacongang. MAN Pinrang. Perguruan tinggi IAIN Parepare

Motto hidup:

"Tetap Semangat Dalam Berproses" 


\section{Mappanre Temme}

Mappanre Temme adalah sebuah tradisi yang lahir dari pengumpulan kebijaksanaan masyarakat Bugis sebagai salah satu bentuk penghargaan bagi anak-anak yang telah menamatkan bacaan al-qurannya baik itu prempuan maupun laki-laki.

Mengapa melaksanakan tradisi mappanre temme? "Karena tradisi mappanre temme adalah keputusan para leluhur Suku Bugis dahulu yang harus dijalankan sampai sekarang. Dan hal ini dilaksanakan sebagai bentuk penghargaan masyarakat karena telah berhasil menamatkan bacaan Al-qurannya". Kemudian tradisi tersebut wajib dilaksanakan sebagai wujud ketaatan masyarakat Bugis terhadap Allah swt". Narasumber, Sartia.

Bentuk upacara mappanre temme adalah bagi anak-anak yang sudah tamat mengaji dan pelaksanaanya pun bisa dilakukan secara seorang diri dalam kumpulan keluarga besar atau upacara ini juga bisa dilakukan secara bersama dimana 2 atau 4 anak. Dan adapula yang melaksanakan upacara ini pada saat mereka ingin melaksanakan sebuah pernikahan. (cmdzirhistorian.blogspot.com)

Mengaji atas perintah wahyu pertama Allah swt kepada Rasulullah Muhammad saw melalui perantara malaikat Jibril. Allah memerintahkan manusia agar senantiasa membaca al-quran dan mengkajinya serta memperdalam ilmu agamanya. Proses pelaksanaan kegiatan menamatkan Al-quran timbul sebagai efek dari proses pengislaman atau perkembangan Islam. Proses pengembangan Islam ditempuh dalam berbagai aturan, salah satunya mengadakan pengajian Al-quran bagi anak-anak dan orang dewasa. Penanaman Islam cenderung memiliki efek bagi setiap peminat tradisi ini.

Efek yang muncul tentu bukan sembarangan, efek ini memberi perubahan cara hidup kita dan perubahan etika dalam kehidupan bermasyarakat. Hal ini didasari dengan adanya nilai-nilai mulia yang terkandung dalam tradisi mappanre temme dan dapat diaplikasikan dalam kehidupan. Dalam perkembangan penyebaran 
Islam dibentuk Parewa Syara' yang dipimpin oleh seorang qadhi. Parewa Syara' berperan penting dalam penyelenggaraan kegiatan membaca Al-quran yang biasa dilaksanakan di masjid ataupun di rumah guru mengaji.

Dari sinilah yang membentuk sebuah budaya yang mengakar di tengah kehidupan masyarakat yakni mappanre temme. Sebuah tradisi khatam Al-quran bagi yang tamat mengaji, tentu dalam pelaksanaanya memiliki tata cara tersendiri di dalamnya. Tetapi melihat realitas sekarang tradisi ini mulai surut. Perlu dipahami bahwa tradisi mappanre temme' yang lahir dari sebuah komunitas masyarakat Islami ini, merupakan tradisi yang mengandung nilainilai bermanfaat bagi masyarakat, sehingga keberadaaan tradisi tersebut dapat di pertahankan masyarakat. (https://researchgate.net/publication)

Mappanre temme dalam bahasa Indonesia diartikan sebagai proses tammatan Al-Qur'an khususnya anak-anak yang telah menyelesaikan bacaan Al-Qur'an-nya, agar guru mengaji lepas dari tanggung jawab.Mappanre temme sekedar sebuah tradisi pada saat tamat mengaji. "tradisi mappanre temme adalah salah satu proses penyelesaian untuk menamatkan bacaan Al-quran dan sebagai bentuk rasa syukur para guru mengaji karena muridnya yang telah menamatkan bacaan Al-qurannya". Narasumber, Sartia.

Tradisi ini memiliki arti yang sangat mendalam khususnya bagi masyarakat Bugis, ada beberapa proses pelaksanaan mappanre temme dimulai dari mempersiapkan segala hal yang dibutuhkan dalam penyelenggaraan upacara mappanre temme dapat dilihat dibawah ini:

1. Sokko, harus ada dalam setiap penyelenggaraan tradisi adat Bugis terutama tradisi mappanre temme

2. Ember kecil yang berisi sokko,ayam dan telur yang diberikan kepada guru mengaji.

3. Kue yang wajid ada dalam mappanre temme seperti barongko, onde-onde, doko-doko cangkuning, cucuru, bandang dan lapisi. Kue yang lain sebagai hidangan menjamu tamu.

4. Murid membawa 2 ekor ayam dan 3 sisir pisang sebagai ucapan terima kasih seorang murid kepada gurunya 
5. Selanjutnya diadakan barasansi, setelah barasanji selesai mulailah menyelenggaraan membaca Al-Qur'an bagi murid yang ingin menamatkan mengaji dalam tradisia mappanre temme.Kemudin dilanjutkan membaca surah al-duha sampai al-fatihah. Namun ketika sampi pada surah al- Ikhlas, al-Falak dan an-Nas surah tersebut dibaca 3 kali, dan diharuskan membaca kalimat tahlil dan tahmid (La Ilaha Illallah wa lillah I/ham).

6. Kemudian guru mengaji memberikan makanan kepada muridnya, setelah itu berakhirlah seluruh rangkaian tradisi Mappanre Temme.

Nilai, yaitu prilaku atau hal-hal yang penting bagi kemanusiaan. Jika arti dari nilai dikaitkan dengan budaya maka bisa berarti bahwa konsep abstrak mengenai masalah dasar yang sangat penting dan bernilai dalam kehidupan manusia[. Dalam hal ini sesuatu bisa bernilai jika memiliki sifat atau hal-hal yang penting bagi Masyarakat. Oleh karena itu, dalam mewujudkan eksistensi dari tradisi Mappanre Temme', maka diperlukan nilai-nilai yang tetap menjaga keberadaan tradisi tersebut.

Menggunakan berbagai pendekatan, mappanre temme' jika dicermati dari segi pelaksanaan dari awal hingga akhir tidak terlepas dari manusia sebagai makhluk sosial. Mulai dari persiapan kuekue, songkolo, ayam, salosso', Alquran dan lain sebagainya. Hingga pada tahap pelaksanaan mappanre temme itu sendiri, melalui penjabaran pelaksanaan kegiatan di atas dapat diambil beberapa nilai-nilai sosial, berlaku bagi individu yang hidup dalam masyarakat maupun masyarakat dengan masyarakat lain.

Bagaimana cara mempertahankan tradisi mappanre temme tersebut?" untuk mempertahankan tradisi ini, harus ada generasi yang paham betul dengan tradisi tersebut. Sehingga jika ada yang paham mengenai tradisi tersebut maka tradisi ini tidak akan hilang. Tradisi ini pasti akan dilaksanakan dari generasi ke generasi karena ada pemahaman dari nenek moyangnya. Adanya tradisi Mappanre Temme tersebut, masyarakat Suku Bugis dikenal sebagai Suku yang tidak menghilangkan tradisinya meskipun zaman semakin modern. Mereka tetap mempertahankan tradisi tersebut". Narasumber, Sartia. 
Tradisi Mappanre Temme ini dari zaman dahulu dilaksanakan oleh keturunan suku Bugis hingga sampai saat ini tradisi ini tidak pernah dihilangkan. Jadi setiap keluarga yang melaksanakan tradisi ini pasti keturunan selanjutnya harus melaksanakan tradisi tersebut. Mappanre temme ini bisa dilakukan tidak hanya dalam naungan keluarga sendiri namun hal ini bisa dilakukan pada saat keluarga yang lain melaksanakannya.

Misalnya ada keluarga yang sedang melaksanakan upacara mappanre temme kita bisa mengikut di upacara tersebut tetapi hal ini hanya ikut dalam naungan keluarga saja belum dalam menggugurkan kewajiban bagi pribadi yang ingin menamatkan bacaan Al-qurannya karena mappanre temme ini dinyatakan selesai atau sah apabila telah dilakukan oleh orang tua si anak ini sendiri baru dikatakan mappanre temme ini sah, sah telah dilaksanakan oleh keluarganya. Jadi mappanre temme tidak memandang usia seseorang dalam melaksanakan adat ini namun kapan saja orang tua dari anak ini mampu melaksanakan mappanre temme ini. Dalam tradisi adat Bugis semua orang dinyatakan harus melaksanakan mappanre temme sebelum menikah.

Namun karena adanya tradisi mappanre temme yang dilakukan adat Bugis yang tata caranya cukup menghabiskan banyak uang, oleh karena itu banyak anak-anak maupun orang dewasa belum menamatkan bacaan Al-qurannya dikarenakan orang tua mereka tidak mampu membuat acara tersebut. Dan jika bisa tata cara atau persediaan mappanre temme tidak diharuskan merayakan seperti membuat acara (syukuran), cukup dengan memanggil guru mengaji tersebut untuk menamatkan bacaan Al-qurannya.

Nilai-nilai dalam tradisi mappanre temme ini tidak terlepas dari campur tangan manusia. Hal ini semakin mempererat ikatan manusia karena tradisi ini memerlukan yang namanya gotong royong masyarakat.

Mappanre temme dalam bahasa Indonesia diartikan sebagai proses tammatan Al-Qur'an khususnya anak-anak yang telah menyelesaikan bacaan Al-Qur'an-nya, agar guru mengaji lepas dari tanggungjawab. Mappanre temme sekedar sebuah tradisi pada saat tamat mengaji. 
Ada beberapa proses pelaksanaan mappanre temme dimulai dari mempersiapkan segala hal yang dibutuhkan dalam penyelenggaraan upacara Mappanre Temme dapat seperti: sokko, ember kecil, kue, 2 ekor ayam dan 3 sisir pisang. 


\section{Biodata Penulis}

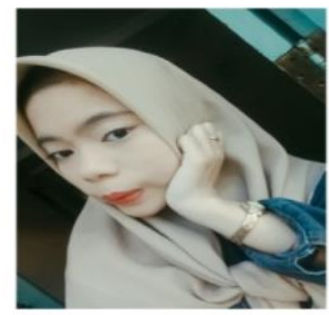

Nur Asiah dilahirkan di Lahaddatu, tepat tanggal 02 September 2000. Ia punya hobi mendengarkan musik dan traveling. Bercita-cita menjadi seorang Perawat . Saat ini sedang menjadi Mahasiswa di IAIN Parepare. Mengambil Prodi Jurnalistik Islam. Hal ini harus dijalankannya meskipun ia belum menerima kenyataan bahwa ia tidak akan pernah menjadi seorang perawat lagi. Mulai detik ini ia akan mencoba mencintai jurusannya saat ini dan akan cinta sampai kapanpun. Karena ia suka yang berbaur dengan yang namanya travelling maka Prodi ini sangat cocok untuknya. Karena Prodi ini selalu berbaur dengan lapangan. Jejaknya bisa dilacak melalui akun facebook @Nuraisyah Samsuddin. Instagramnya @Ichaae09. Prinsipnya "tetaplah menjadi pribadi sendiri tanpa harus menjadi orang lain." 


\section{Tradisi "Ma'baca Baca"}

Tradisi adalah kebiasaan, suatu aktivitas turun-temurun dari leluhur kita, yang biasanya dilakukan warga masyarakat dengan melakukan semacam ritual. Sesuatu yang telah dilakukan sejak lama dan menjadi bagian dari kehidupan suatu kelompok masyarakat, informasi yang diteruskan dari generasi ke generasi baik tertulis maupun lisan, karena tanpa adanya ini suatu tradisi akan punah.

Sungguh luar biasa keanekaragaman budaya yang dimiliki bangsa Indonesia, termasuk di dalamnya ada sistem religi maupun sistem kepercayaan yang hidup dan dihayati oleh masyarakat di setiap suku bangsa. Perlu disadari dan dipahami, kontribusi kepercayaan masyarakat bagi bangsa Indonesia jelas tidak sedikit. Selain merupakan salah satu akar bagi tumbuh kembangnya kebudayaan Indonesia, kepercayaan masyarakat juga memberi ciri kebudayaan daerah setempat, yang lebih hakiki lagi, dan memberikan kepercayaan-kepercayaan kepada masyarakat yang mengandung makna dan nilai-nilai yang sangat bermanfaat bagi kehidupan manusia.

Salah satu suku di Indonesia yang masih melestarikan tradisi mereka adalah suku Bugis. Suku Bugis memiliki banyak tradisi dan budaya yang masih mereka pertahankan sampai sekarang. Salah satunya adalah tradisi ma'baca baca.

Apakah kalian pernah mendengar tradisi ma'baca baca? Yah, salah salah satu tradisi warisan nenek moyang dan para leluhur yang masih banyak dilakukan masyarakat sampai saat ini.

Ma'baca baca berasal dari bahasa bugis yang berarti membaca doa. Ma'baca baca pada hari lebaran ialah ritual membacakan doa pada makanan sebagai ucapan syukur dan memohon keselamatan kepada Allah SWT. Ritual ini dilakukan oleh imam atau tokoh masyarakat yang telah mendapat kepercayaan. Ritual ini bukan hanya meminta keselamatan untuk keluarga yang masih hidup, tetapi juga ikut mendoakan keluarga mereka yang telah meninggal. 
Proses pelaksanaan tradisi ma'baca baca pada hari raya Idulfitri dilaksanakan di rumah masing-masing sepulang dari salat Idulfitri. Dalam proses pelaksanaanya, hal utama yang perlu dipersiapkan adalah bahan-bahan yang akan digunakan dalam tradisi membaca doa tersebut. Menurut seorang masyarakat yang masih melakukan tradisi ini, hidangan yang dipersiapkan antara lain ayam opor, beras ketan atau yang disebut "sokko atau songkolo", buras atau burasa, buah-buahan, ikan, tape, dupa, dan lain sebagainya.

Awal dari kegiatan ritual ma'baca baca adalah dengan membakar dupa yang diberi kemenyan oleh imam dan dibacakan doa dengan menggunakan bahasa bugis dan melanjutkan dengan membacakan ayat-ayat suci Al-Quran, serta mendoakan keluarga yang telah meninggal. Aroma kemenyan akan menyebar ke seluruh bagian rumah, kemudian imam akan memegan baki secara bergantian sebagai tanda dia telah mendoakan makanan tersebut. Terkadang ada keluarga yang harus menunggu giliran dibacakan doa hingga larut malam demi menunggu imam yang berpindah dari satu rumah ke rumah lainnya.

Salah satu fungsi dari ma'baca baca ialah sebagai sarana silaturahmi dan mempererat tali persaudaraan antar sesama. Kegiatan ini dilakukan masyarakat untuk mengundang keluarga, tetangga, teman untuk berkunjung kerumah mereka.

Bagian-bagian dalam membaca doa pada hari lebaran antara lain doang salama' atau doa selamat, baca doang bariala atau doa untuk orang yang sudah meninggal, dan doa keselamatan untuk rumah.

1. Baca Doang Salama merupakan bacaan do'a keselamatan bagi keluarga.Tradisi ini dilaksanakan dengan tujuan agar keluarga yang masih hidup diberi keselamatan di dunia. Dalam sajiannya ini terdiri dari makanan yang disajikan dengan piring kecil dan mangkuk yang berisi lauk pauk kemudian diletakkan di atas dua nampan.

2. Doang bariala Merupakan do'a atau pengiriman makanan pada orang tua yang sudah meninggal terdiri dari sajian makanan yang disajikan dengan piring kecil dan mangkuk yang berisi lauk pauk seperti masakan ayam, ikan goreng kemudian diletakkan di atas dua nampan setelah itu 
pembaca do'a menghadapi kedua nampan tersebut seraya membakar kemenyan serta membacakan do'a yang. Menurut keyakinan mereka dengan menyajikan makanan kemudian dibacakan do'a merupakan suatu bentuk permohonan kepada Allah SWT agar makanan yang dibaca dapat sampai kepada orang tua mereka yang sudah meninggal.

3. Baca do'a keselamatan untuk rumah merupakan sajian makanan yang biasanya berupa hati ayam dan lambung ayam karena diyakini bahwa rumah yang ditempati memiliki penjaga yang hanya menyukai makan-makanan tersebut, makanan tersebut disajikan di pusat rumah "Possi Bola" Pembacaan do'a untuk rumah merupakan bagian dari Mabbaca Doang pada hari raya Idulfitri yang dilaksanakan setelah semua bagian yang lain selesai dibacakan do'a. Hal ini diyakini oleh masyarakat Bugis perantauan di Desa Tombekuku dengan melakukan pembacaan do'a disertai dengan sajian makanan memiliki tujuan agar pemilik rumah diberikan keselamatan dalam menempati rumahnya yang baru, seperti agar terhindar dari roh jahat yang dapat menggangu ketenangan mereka selama rumah tersebut di tempati atau di masuki. (Muh. Aking)

Unsur religi memang sangat terasa dalam tradisi ini. Seperti yang diungkapkan salah satu masyarakat tentang pantangan apabila tradisi ini tidak dia lakukan. Ia percaya bahwa apabila ritual ini tidak dilakukan maka suatu musibah akan terjadi pada keluarganya. "ma'baca baca sudah na lakukan keluargaku dari dulu bahkan sebelum ka' lahir, dan ini memang haruski teruskan'i karena warisannya ini orang tua dulu. Saya dengan keluargaku percaya kalau ini tidak dilakukan akan terjadi musibah di keluargaku. Dengan ma'baca baca juga bisaka kirimkan doa keluargaku yang sudah meninggal." Ungkapnya.

Namun tidak dapat dipungkiri bahwa ritual ma'baca baca ini juga ditentang sebagian orang yang menganggap kegiatan ini adalah kemusyrikan. Ritual ini dianggap musyrik karena tidak diajarkan oleh 
agama karena menyediakan makanan untuk orang meninggal. tidak pernah keluargaku ma'baca baca karena tidak pernah diajarkan di agama mendoakan orang meninggal menggunakan makanan. Musryik semua yang begitu." Ungkap Angga, masyarakat yang menentang tradisi ini.

Ma'Baca-baca sendiri bagi kalangan suku Bugis-Makassar tidak dianggap sebagai sebuah kesyirikan. Mengingat doa yang dipanjatkan bukanlah berupa mantera, melainkan salawat dan sederet ayat-ayat Alquran yang ditujukan kepada Allah swt. Dimana, di Suku Bugis sendiri tradisi ini memunculkan sebuah kolaborasi antara adat istiadat dengan agama. (Rio Anthony)

Kita sekarang hidup di zaman moderen yang mana semakin banyak tradisi budaya yang sudah hilang. Untuk melestarikan budaya ini kita dapat mengajarkannya kepada generasi penerus dan mencintai budaya sendiri. Beberapa saran atau solusi agar budaya tradisi tetap lestari, antara lain: Masyarakat membantu melestarikan budaya yang telah diwariskan oleh para leluhur dan nenek moyang kita. Mengajarkan kebudayaan itu pada generasi penerus sejak dini sehingga kebudayaan itu tidak musnah dan tetap dapat bertahan. Mencintai budaya sendiri tanpa merendahkan dan melecehkan budaya orang lain serta menerima segala perbedaan dalam berbudaya. Berusaha menghidupkan kembali semangat toleransi, kekeluargaan, keramah-tamahan dan solidaritas yang tinggi. Selalu mempertahankan budaya Indonesia agar tidak punah.

Dalam ritual ma'baca baca masyarakat suku bugis percaya bahwa mereka akan mendapatkan keselamatan dari Allah swt. Dan dengan melakukan tradisi ini mereka bisa mempererat tali silaturahmu dengan keluarga, teman, dan tetangga mereka. Dalam tradisi ini, semua golongan masyarakat bisa melakukannya. Tidak ada pembatasannya ekonomi dalam melaksanakan tradisi ini. Tradisi ini juga diyakini menjadi media pengirim doa kepada keluarga mereka yang telah meninggal dunia. Walaupun terdapat beberapa pandangan berbeda tentang tradisi ini dalam kehidupan beragama, masyarakat bugis tidak menganggapnya sebagai sebuah permusuhan atau perselisihan namun mereka tetap menjaga tali persaudaraan diantara mereka sampai saat ini. 


\section{Biodata Penulis}

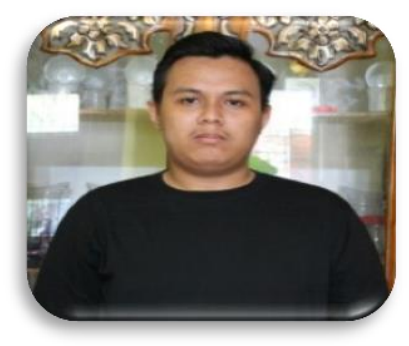

Zulfikar Anindatama Haerul, lahir di kabupaten Enrekang pada tanggal 16 Mei 1999. Anak kedua dari tiga bersaudara. Memiliki hobi bermain futsal dan bercita-cita menjadi oarng sukses. Pada tahun 2004 memulai pendidikan di bangku taman kanak-kanak Bhayangkari selama 1 tahun. Pada tahun 2005 melanjutka sekolah dasar di SD Negeri 17 Parepare selama 6 tahun. Kemudian melanjutkan pendidikan tingkat menegah pertama di SMP Negeri 4 Parepare selama 3 tahun. Pada tahun 2014 melanjutkan pendidikan tingkat menengah atas di SMA 4 Parapare. Setelah lulus di bangku SMA pada tahun 2017, kemudian melanjutkan pendidikan perguruan tinggi di Institud Agama Islam Negeri (IAIN) Parepare jurusan Jurnalistik Islam Fakultas Fakultas Ushuluddin Adab Dan Dakwah (FUAD).

MOTTO HIDUP:

"HIDUP SUKSES DAN MENSUKSESKAN ORANG LAIN" 


\section{Paradoksal Dialek Bugis Bone dan Bugis Sidenreng Rappang(Sidrap) di Sulawesi Selatan}

Manusia sebagai makhluk individu dan makhluk sosial memiliki keinginan untuk selalu berkomunikasi dan bekerja sama antara sesamanya dengan menggunakan bahasa. Ketika berinteraksi antara pengguna bahasa yang satu dengan pengguna bahasa yang lain, akan timbul suatu kontak bahasa. Dengan bahasa seseorang akan memiliki berbagai informasi dan ilmu pengetahuan.

Bahasa merupakan sarana untuk berkomunikasi antar sesama. Melalui bahasa manusia dapat mengekspresikan ide dan gagasan yang ada di dalam pikiran. Di dunia ini terdapat berbagai macam bahasa yang digunakan untuk berkomunikasi. Komunikasi ini dapat dilakukan dengan dua cara, yaitu secara lisan dan secara tertulis. Komunikasi yang dilakukan secara lisan menggunakan bunyi bahasa. Kejelasan informasi dalam bahasa lisan didukung oleh penggunaan intonasi, gerak tubuh, perubahan suara, dan jarak berbahasa secara fisik. Dalam penggunaan bahasa, terdapat aturan-aturan pemakaian bahasa yang dapat membantu mengerti maksud yang dibicarakan sesuai dengan konteks dan keadaan.

Fenomena kebahasaan dapat terjadi karena adanya kontak bahasa, khususnya di daerah perbatasan yang berbatas dengan yang berbeda kabupaten dan suku. Pengaruh pemakaian bahasa (bahasa ibu) dalam melakukan kontak bahasa dapat menentukan keberlangsungan bahasa yang digunakan oleh dua suku atau etnis. Situasi kebahasaan ini menggambarkan bahwa telah terjadi kontak bahasa antara bahasa ibu dan bahasa dari etnis lainnya. Peristiwa kontak bahasa yang terjadi pada masyarakat bilingual dapat menjadi objek kajian sosiolinguistik. Sumarsono dan Patana (2004) mendefinisikan sosiolinguistik sebagai ilmu linguistik institusional yang berkaitan dengan pertautan bahasa dengan orang-orang yang memakai bahasa itu. Dalam ilmu sosiolinguistik dibicarakan bagaimana penutur bahasa menggunakan bahasa yang bervariasi dari sejumlah ragam bahasa yang digunakan oleh masyarakat. 
Bahasa yang digunakan untuk berkomunikasi antara orang yang satu dengan yang lain memiliki perbedaan. Perbedaan bahasa yang digunakan terdapat pada lafal, intonasi, dan struktur kalimatnya. Perbedaan-perbedaan tersebut menyebabkan adanya variasi bahasa. Variasi bahasa ini memiliki beberapa ragam. Salah satunya adalah dialek. Dialek merupakan variasi bahasa yang pemakaiannya berbeda-beda baik dalam segi bunyi, kosa kata, morfologi, maupun leksikonnya, yang disebabkan oleh faktor geografis, misalnya dalam Bahasa Bugis, dialek bugis bone,bugis sidenreng rappang, dll. Dialek-dialek tersebut membuat bahasa bugis semakin beragam.

Istilah Bugis menurut Kamus Dewan bermakna suku bangsa yang berasal dari Sulawesi Selatan, Indonesia yang terkenal sebagai pelaut (Kamus Dewan, 2010: 212). Suku ini juga merupakan bagian dari suku etnik lainnya di wilayah Sulawesi yaitu termasuk kelompok suku bangsa Toraja, Mandar, dan Makassar. Orang Bugis kini dengan populasinya mencapai 4 (empat) juta yang mendiami hampir kesemua kawasan Sulawesi Selatan di mana kebanyakan agama yang dianut oleh mereka adalah agama Islam. Suku ini merupakan suku bangsa yang menyebar dan merantau hampir ke seluruh kawasan pesisir pantai kepulauan nusantara Indonesia, asal nenek moyang mereka dikatakan berasal dari Sulawesi Selatan.

Sejarah suku bugis yang dikenal dengan Perantauan ini masih mengekalkan pengaruh kehidupan mereka dalam seni dan budaya, saling berhubung dan berkomunikasi serta persaudaraan yang erat antara satu dengan lainnya. Amalan cara hidup mereka masih diamalkan dengan berlandaskan hukum adat istiadat yang kental, pemali dan pantangan. Orang Bugis kebanyakan menganut agama Islam sebagai keyakinan hidup, di samping mereka tetap mewariskan prinsip hidup siri, pesse dan ade' secara turun temurun kepada keturunannya agar dapat menjalani kehidupan ini dengan baik, walau mesti dihadapi dengan berbagai rintangan sehingga kapanpun.

Bugis adalah kelompok etnik dengan wilayah asalnya adalah di Sulawesi Selatan. Ciri utama dari kelompok ini adalah 
bahasa dan adat-istiadat. Bugis adalah suku yang tergolong ke dalam suku melayu deutro. Pengelompokan bahasa di Sulawesi dalam buku Bahasa dan Peta Bahasa Indonesia dikeluarkan oleh Pusat Bahasa Depdiknas (Sugono, 2008:71) menunjukkan bahwa bahasa daerah di Sulawesi ada 58 dan khusus di Sulawesi Selatan ada 14 bahasa. Pengelompokan tersebut telah memberikan informasi baru mengenai pemetaan bahasa-bahasa yang ada di Indonesia. Khusus di wilayah Sulawesi Selatan ditemukan beberapa bahasa yaitu bahasa Bugis, bahasa Makassar, bahasa Toraja, bahasa Massenrepulu, bahasa Pamona, bahasa Wotu, bahasa Seko, bahasa Rampi, bahasa Lemolang, bahasa Bugis De', bahasa Bonerate, bahasa Konjo, bahasa Laiyolo, dan bahasa Bajo. Sedangkan SIL dalam Bahasa dan Peta bahasa di Indonesia (Sugono, 2008:76) membagi dialek Bugis menjadi sebelas dialek yaitu, dialek Palakka, dialek Pangkajene, dialek Camba, dialek Sidrap, dialek Pasangkayu (Ugi Riawa), dialek Sinjai (Ennak), dialek Soppeng (Kessi), dialek Wajo, dialek Barru, dialek Sawitto (Pinrang), dan dialek Luwu. (Jurnal Sawerigading: 2014)

Melalui tulisan ini, penulis ingin menjelaskan perbedaan dialek bugis yang beranekaragam di Sulawesi Selatan, khususnya dialek bugis bone dan bugis sidrap. Dengan berlandaskan pada teori dialektologi. Dialektologi adalah subbidang sosiolinguistik yang mempelajari dialek atau variasi bahasa dalam suatu komunitas masyarakat tertentu. Bidang ini mengkaji variasi bahasa berdasarkan distribusi geografis yang ditampilkan melalui peta bahasa serta mencakup topik seperti percabangan dua dialek lokal dari induk bahasa yang sama dan variasi sinkronis. Dialektologi ingin memelajari serta membanding-bandingkan bahasa-bahasa yang masih serumpun untuk mencari titik persamaan dan titik-titik perbedaannya. Dialektologi disebut pula variasi bahasa berdasarkan geografi, tetapi hendaknya kita ingat bahwa dialektologi tidak sama dengan studi tentang dialek (Pateda, 1988: 51)

Jangan mengira semua daerah di Sulawesi Selatan berbahasa Bugis. Ada pula bahasa Makassar dan Toraja. Selain itu ada juga sub bahasa daerah. Ada berbagai macam dialek di Sulawesi Selatan. Sulawesi Selatan yang dikenal dengan empat etnisnya yaitu makassar, mandar, bugis dan toraja. Dari keempat etnis tersebut 
penulis akan membahas lebih jauh tentang bugis. Khusunya tentang dialek atau bunyi bahasa. Dialek bugis terbagi menjadi beberapa macam, yaitu bugis barru, bugis bone, bugis sidrap, bugis sawitto, bugis soppeng.

Bahasa Bugis terdiri dari beberapa dialek. Seperti dialek Pinrang yang mirip dengan dialek Sidrap. Dialek Bone (yang berbeda antara Bone utara dan Selatan). Dialek Soppeng. Dialek Wajo (juga berbeda antara Wajo bagian utara dan selatan, serta timur dan barat). Dialek Barru, Dialek Sinjai dan sebagainya. Masyarakat Bugis memiliki penulisan tradisional juga memakai aksara Lontara. (wikipedia, dialektologi: 2020)

Bahasa Bugis adalah salah satu dari rumpun bahasa Austronesia yang digunakan oleh etnik Bugis di Sulawesi Selatan, yang tersebar di sebagian Kabupaten Maros, Kabupaten Pangkep, Kabupaten Barru, Kota Parepare, Kabupaten Pinrang, sebahagian kabupaten Enrekang, sebahagian kabupaten Majene, Kabupaten Luwu, Kabupaten Sidenreng Rappang, Kabupaten Soppeng, Kabupaten Wajo, Kabupaten Bone, Kabupaten Sinjai, sebagian Kabupaten Bulukumba, dan sebagian Kabupaten Bantaeng. Dari beberapa bahasa bugis tersebut hal yang menarik adalah bugis bone dan sidrap yang bisa dikatakan sama-sama berbahasa bugis namun sangatlah memperlihatkan perbedaan yang menonjol.

Menurut sejarah, Sidenreng Rappang awalnya terdiri dari dua kerajaan, masing-masing Kerajan Sidenreng dan Kerajaan Rappang. Kedua kerajaan ini sangat akrab. Begitu akrabnya, sehingga sulit ditemukan batas pemisah. Bahkan dalam urusan pergantian kursi kerajaan, keduanya dapat saling mengisi. Seringkali pemangku adat Sidenreng justru mengisi kursi kerajaan dengan memilih dari komunitas orang Rappang. Begitu pula sebaliknya, bila kursi kerajan Rappang kosong, mereka dapat memilih dari kerajaan Sidenreng. Itu pula sebabnya, sulit untuk mencari garis pembeda dari dua kerajaan tersebut. Dialek bahasanya sama, bentuk fisiknya tidak beda, bahasa sehariharinya juga mirip. Kalaupun ada perbedaan yang menonjol, hanya dari posisi geografisnya saja. Wilayah Rappang menempati 
posisi sebelah Utara, sedangkan kerajaan Sidenreng berada di bagian Selatan.

Bahasa bugis sidrap hampir sama dengan bahasa bugis lainnya. Namun sidrap dikenal dengan intonasi berbicara yang tinggi. Masyarakat sidrap kental dengan bahasa bugisnya dan dialek yang begitu kentara. Bagi orang sulawesi tentunya bisa langsung tahu dari sekali mendengar orang sidrap berbicara.

Setiap desa di sidrap itu mempunyai ciri khas dialek yang berbeda-beda pula. Salah satunya yaitu kampung dare, masyarakat disana ketika berbicara biasa menambahkan kata mbe disetiap kalimatnya. Ada juga kampung yang biasa menambahkan kata menna di kalimatnya saat berbicara. Salah satu daerah di Sidrap, yaitu Baranti juga mempunyai ciri khas saat berbicara. Orang Baranti kalau bicara mengatakan kata "tadi/barusan" dalam bahasa bugis ia mengatakan ongna sedangkan beberapa orang disidrap juga biasa mngetakan nangnge.

Dialek masyarakat di sidrap kebanyakan menggunakan koma atas jika dijelaskan melalui tulisan. Misalnya "Sidrap kebanyakan koma atas misal scoubat dia bilang scouba' (koma atas disini bermaksud untuk penekanan intonasi diakhiran saat berbicara)" ungkap Resky Ramadhan salah satu mahasiswa IAIN Parepare yang berasal dari Sidrap.

Kabupaten Bone sendiri adalah salah satu daerah otonom di provinsi Sulawesi Selatan, Indonesia. Ibu kota kabupaten ini terletak di kota Watampone. Kabupaten Bone tergolong kabupaten yang besar dan luas di Sulawesi Selatan. Rata-rata jumlah penduduk per km2 adalah 162 jiwa. Terkait dengan perannya sebagai pusat pemerintahan, pendidikan, dan fasilitas publik lain, maka mayoritas penduduk tinggal terpusat di ibu kota kabupaten. Kepadatan penduduknya mencapai 1.111,78 jiwa per km2.

Bahasa bugis bone sendiri juga hampir sama dengan bahasa bugis lainnya. Namun bugis bone dikenal dengan intonasi berbicara lembut dan mendayu-dayu. Masyarakat bone dikenal sangat sopan dalam berbicara dikarenakan intonasi berbicaranya yang lembut. Bahkan terkadang orang Sulawesi mengatakan "lebih baik dimarahi orang bone daripada dibisiki oleh orang sidrap" Seorang mahasiswa IAIN Pare-pare yang berasal dari bone 
mengatakan "Mungkin menurut perespektif saya pribadi kalau dari segi intonasi itu di bone agak lembut sedikit ketimbang Parepare, Pinrang dan Sidrap. Misalnya kalau di bone kebanyakan akhiran ki, seperti dimanaki, sedangkan di Parepare dimanako. Tapi saya pribadi tidak menjadikan itu sebagai kata-kata yang kasar, karena itu memang bahasa mereka dan harus kita terima sebagai orang pendatang di sini. Jadi intinya menyesuaikan saja. Sebagai orang pendatang tentunya kita yang mengikut dengan bahasanya, bukan mereka yg mengikuti bahasa kita"

Ada beberapa kosakata yang berbeda selain dialek. Misalnya, dialek Pinrang dan Sidrap menyebut kata Loka untuk pisang. Sementara dialek Bugis yang lain menyebut Otti atau Utti. Selain itu rokok di Sidrap disebut "pelo" sedangkan di Bone disebut "tole".

Bahasa Bugis terdiri dari beberapa dialek. Seperti dialek Pinrang yang mirip dengan dialek Sidrap. Dialek Bone (yang berbeda antara Bone utara dan Selatan). Bahasa ataupun dialek bukan lah pembeda yang memisahkan. Namun itulah kekayaan yang dibentuk dari budaya orang terdahulu. Dialek sidrap dan bone tidaklah salah dan saling menjatuhkan. Namun ada ciri khas dari masing-masing dialek bahasa bugis tersebut. 


\section{Biodata Penulis}

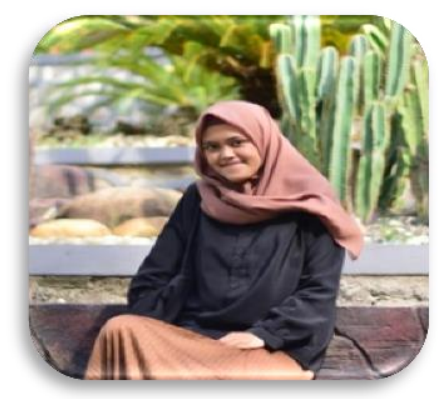

Siti Nurhaliza Muhlis Lahir di Pinrang, Sulawesi Selatan. Pada 13 Januari 1999. Ia adalah mahasiswa dari Institut Agama Islam Negeri (IAIN) Parepare, dengan program studi (prodi) Jurnalistik Islam. Lahir dari orang tua bernama Muhlis (ayah) dan Nursiah (ibu), sebagai anak ke-dua dari empat bersaudara.

Penulis menempuh pendidikan di Kota asalnya yaitu dimulai dari SDN 5 Pinrang (lulus tahun 2011), melanjutkan ke SMPN 1 Pinrang (lulus tahun 2014), dan SMAN 1 Pinrang (lulus tahun 2017), hingga akhirnya bisa menempuh masa kuliah di Fakultas Ushuluddin, Adab dan Dakwah IAIN Parepare, Sulawesi Selatan pada tahun 2018.

Pemilik akun instagram @nhlizhaa13 ini menyukai photography dan juga cinematography. Passionnya dalam mengedit gambar ataupun video membuatnya sangat ingin menjadi konten kreator Atau produser. Itulah yang menjadi salah satu alasan mengapa ia memilih kuliah Prodi jurnalistik Islam. 


\section{Budaya Uang Panai}

Dalam kompleksitas budaya pernikahan pada masyarakat Bugis ada nilai-nilai yang tak lepas untuk menjadi landasan dalam pernikahan, seperti status social, ekonomi, dan nilai-nilai budaya dari masing-masing keluarga pria dan wanita. Suatu hal yang menjadi ciri khas pernikahan masyarakat setempat adalah uang panai, banyak yang gagal menikah karena tingginya uang panai.

Uang panai itu sendiri adalah sejumlah uang yang harus diserahkan oleh pihak laki-laki kepada pihak perempuan. Terkait berapa jumlah uang panai yang harus diberikan tidak selalu sama antara satu dengan yang lainnya, semua tergantung pada kesepakatan antar keluarga kedua belah pihak. Besaran uang panai tidak tanggung-tanggung bagi masyarakat yang kelas ekonominya menengah ke bawah. Nilainya bisa mencapai puluhan bahkan ratusan juta, kita seringkali mendengar, melihat di media sosial, orang tua melamar seorang gadis dengan uang panai yang begitu tinggi, seolah-olah uang panai menjadi barometer diterima atau tidaknya seseorang yang datang melamar.

Faktor apa yang mempengaruhi tingginya uang panar? Nilai itu tentunya sangat tergantung dan dipengaruhi oleh beberapa faktor yang diantaranya mulai dari status sosial, pendidikan, bahkan sampai status pekerjaan sang wanita. Sederhananya, semakin tinggi status sosial atau status pendidikan seorang wanita maka semakin tinggi pula uang panai yang diminta oleh keluarga pihak wanita yang hendak dipinang.

Apa tujuan dari pemberian uang panar? salah satu tujuan dari pemberian uang panai adalah untuk memberikan kehormatan, bukti keseriusan laki-laki bagi pihak keluarga perempuan jika jumlah uang panai yang dipatok mampu dipenuhi oleh calon mempelai pria. Kehormatan yang dimaksud adalah rasa penghargaan yang diberikan oleh pihak calon mempelai pria kepada wanita yang ingin dinikahinya. 
Bagaimana pandangan Islam terhadap uang panar? Namun dalam syariat Islam, salah satu rukun pernikahan dalam mazhab Malikiyyah adalah mahar atau syarat. Mahar biasa kita sebut sebagai maskawin, yaitu pemberian wajib bagi calon mempelai pria kepada calon mempelai wanita sebagai perwujudan ketulusan hati. Mahar dalam Islam sudah diatur dengan sangat baik, bahkan pernikahan yang baik adalah pernikahan yang mudah maharnya.

Suku bugis aturan adat yang sering menjadi ujian bagi pasangan yang ingin menikah adalah perihal uang panai. Berat atau tidaknya ujian tersebut, setiap orang punya penilaian sendiri-sendiri karena hal yang menurut kita ujian biasa saja, bisa jadi adalah ujian yang berat bagi orang lain, begitupun sebalikya.

Dikalangan masyarakat Bugis uang panai selalu menjadi sesuatu yang menarik untuk dibicarakan. Dan tidak heran jika mendengar seorang gadis akan menikah, yang lebih dulu ditanyakan adalah: berapa uang panainya?. Pertanyaan ini menjadi sebuah pertanda bagaimana uang panai punya peran penting dalam hal pernikahan suku Bugis. Dalam menentukan jumlah uang panai yang harus disiapkan tidak sembarangan, ada beberapa hal yang menjadi penentunya yaitu status sosial dan tingkat pendidikan. Uang panai untuk perempuan dari kaum bangsawan tentu berbeda dengan uang panai untuk perempuan dari masyarakat biasa. (https://mojok.com)

Menurut sejarahya, ternyata adat uang panai ini mulai muncul ketika zaman penjajahan belanda dulu. Seorang wanita bugis yang berketurunan bangsawan pernah dinikahi oleh seorang laki-laki Belanda. Namun setelah itu laki-laki itu dengan mudahnya meninggalkan wanita Bugis itu dan menikah dengan wanita lain. Keluarga si wanita jelas menjadi geram dengan hal itu sampai akhirmya merasa bahwa anak perempuannya tidak dihargai. Maka menurut versi dari cerita lain yang masih berkorelasi dengan cerita ini adalah bahwa dulu para orang tua justru memang ingin melihat kesungguhan dan keseriusan laki-laki jika ingin meminang anak perempuannya agar dihargai dan nantinya tidak dengan mudahnya meninggalkan wanita yang dipinangnya. Maka bentuk penghargaan nyatanya adalah dengan memberikan uang panai kepada calon istri yang dipinang (www.Kompasiana.com) 
Berdasarkan unsur-unsur yang ada di dalamnya uang panai mengandung tiga makna:

Pertama dilihat dari kedudukannya uang panai merupakan rukun perkawinan dikalangan masyarakat Bugis.

Kedua dari segi fungsinya uang panai merupakan pemberian hadiah kepada pihak mempelai wanita sebagai biaya resepsi pernikahan dalam bekal dikehidupan kelak yang sudah berlaku sejak turun-temurun mengikuti adat istiadat.

Ketiga dari segi tujuaanya pemberian uang panai adalah untuk memberikan prestise (kehormatan) bagi pihak keluarga perempuan jika jumlah uang panai yang dipatok mampu dipenuhi oleh calon mempelai pria. (https://ejournal.unsrat.ac.id)

Namun dalam pandangan Islam, uang panai bukanlah bagian dari syarat sah menikah dan bukan pula salah satu kewajiban yang harus ditunaikan dalam pernikahan. Islam adalah rahmatan lillalamin rahmat bagi seluruh alam, Islam hadir dengan seperangkat aturan yang ada. Islam itu mudah dan tidak memberatkan, selagi apa yang kita kerjakan tidak menentang aturan Islam maka Islam tidak pernah mempersulit aktifitas manusia bahkan melarang hal tersebut terjadi. Seperti halnya pernikahan yang dipersulit dengan uang panai yang cukup mahal.

Syarat sahnya menikah adalah ijab kabul, ada mahar, mempelai laki-laki dan perempuan, wali, dan saksi. Mahar hanya sekedar media dan menikah bukanlah sarana untuk mempersulit mahar yang mahal. Mahar bertujuan untuk memuliakan wanita dan tujuan menikah karena Allah bukan karena mahar. (https://makassar-terkini-.id)

Uang panai atau uang belanja untuk pengantin mempelai wanita yang diberikan oleh pengantin pria merupakan tradisi adat suku Bugis-Makassar di Sulawesi Selatan. Uang panai memiliki kelas sesuai dengan strata sang wanita, mulai dari kecantikan, keturunan bangsawan, pendidikan, hingga pekerjaannya. Masih banyak faktor yang mempengaruhi nilai uang panai, seperti sang gadis misalnya sudah berhaji atau belum.

Uang panai sering kali menjadi bahan perbincangan dikalangan masyarakat. Apalagi di daerah Bugis-Makassar yang cukup populer dengan uang panainya yang cukup tinggi. Sehinnga pemuda yang 
berkeinginan untuk menikah akan berpikir seribu kali sebelum mengkhitbah perempuan yang ingin dinikahinya.

Namun jika dikaji dalam Islam, uang panai bukanlah bagian dari syarat sah menikah dan bukan pula salah satu kewajiban yang harus ditunaikan dalam pernikahan. Islam adalah rahmatanlilalamin rahmat bagi seluruh alam, Islam hadir dengan seperangkat aturan yang ada. Islam itu mudah tidak memberatkan, selagi apa yang kita kerjakan tidak menentang aturan Islam maka Islam tidak pernah mempersulit aktifitas manusia bahkan melarang hal tersebut terjadi. Seperti halnya pernikahan yang dipersulit dengan uang panai yang cukup mahal. Syarat sahnya menikah adalah ijab kabul, ada mahar, mempelai laki-laki dan perempuan, wali dan saksi.

Uang panai itu adalah senyumlah uang yang harus diserahkan oleh pihak laki-laki kepada pihak perempuan. Terkait berapa jumlah uang panai yang harus diberikan tidak selalu sama antara satu dengan yang lainnya, semua tergantung pada kesepakatan antar keluarga kedua belah pihak. Pasalnya, besaran uang panai tidak tanggung-tanggung bagi masyarakat yang kelas ekonominya menengah ke atas. Nilainya bisa mencapai puluhan bahkan ratusan juta. Namun dalam pandangan Islam, uang panai bukanlah bagian dari syarat sah menikah dan bukan pula salah satu kewajiban yang harus ditunaikan dalam pernikahan. 
Biodata Penulis

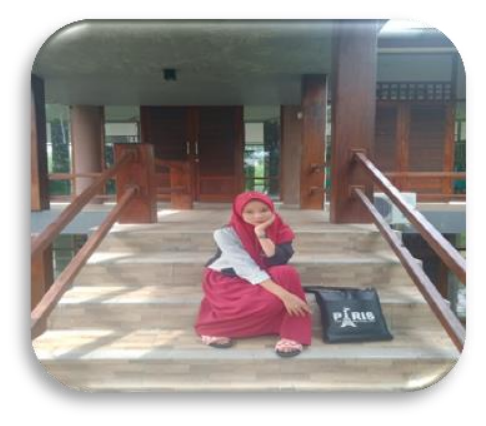

Rahmawati dilahirkan di Enrekang, tepatnya pada tanggal 17 juni 2000. Pada tahun 2006, saya mulai memasuki bangku sekolah dasar. Saat itu saya bersekolah di SDN 186 KARANGAN, Selama 6 tahun lamanya. Setelah itu saya melanjutkan kejenjang SMP. Tepatnya di SMPN SATAP 5 BARAKA, selama 3 tahun lamanya. Pada tahun ajaran 2015, saya lulus dari SMP tersebut. Setelah saya lulus dari SMP saya melanjutkan kejenjang lebih tinggi lagi yaitu jenjang SMK. Disini saya melanjutkan sekolah saya di SMK negeri 2 Parepare, saya mengambil jurusan Teknik Audio Vidio ( elektronika) selama 3 tahun lamanya.Setelah saya lulus dari SMK tersebut saya melanjutkan pendidikan saya disalah satu kampus yang berada di kota Parepare. Yaitu kampus Institut Agama Islam ( IAIN) parepare disini saya mengambil Prodi Jurnalistik Islam pada Fakultas Ushuluddin Adab Dan Dakwah ( FUAD). Dan saat ini saya sedang melanjutkan pendidikan di Institut Agama Islam ( IAIN) parepare. 


\section{Budaya Pakkacaping Tommuane Mandar}

Kata pakkacaping berasal dari kata kacaping yang berarti kecapi dan mendapat awalan " $p a^{\prime \prime}$ yang di dalam bahasa Mandar termasuk awalan yang memuat makna profesi. Setelah kedua unsur tersebut itu digabungkan maka terbentuk sisipan ' $K$ hingga terbentuklah kata pa-k-kacaping.

Pakkacaping tommuane merupakan salah satu seni pertunjukan permainan kecapi yang dimainkan oleh laki-laki, dan juga sebagai salah satu kesenian tradisi Mandar yang berkembang di Sulawesi Barat. Hal ini diartikan bahwa pertunjukan pakkacaping merupakan seni pertunjukan yang berakar dan bersumber dari tata kehidupan masyarakat Mandar. Dalam penyajiannya pertunjukan pakkacaping menggunakan bahasa lokal, yaitu bahasa Mandar dalam menuturkan cerita.

Pakkacaping tommuane dalam masyarakat Mandar merupakan pertunjukan yang memiliki nilai sejarah dan beberapa unsur nilai yang terkandung di dalamnya seperti nilai estetika serta nilai kerohanian yang ditandai dengan adanya beberapa syair yang bertemakan pesan-pesan yang lebih mengarah kepada kerohanian dan mempengaruhi kehidupan keseharian masyarakat Mandar.

Pakkacaping tommuane merupakan salah satu pembentuk karakter orang Mandar pada umumnya melalui pesan-pesan yang digunakan dalam syair lagunya, dan bagi masyarakat Mandar dan pakkacaping tommuane memiliki arti yang sangat penting karena pertunjukan pakkacaping tommuane dianggap sebagai sesuatu yang sakral yang ditandai dengan kepercayaan masyarakat Mandar bahwa ketika menginginkan agar doanya segera terkabulkan maka harus ber-tinjaq (nazar) untuk melaksanakan pertunjukan pakkacaping tommuane apabila doanya segera terkabulkan kemudian apabila doanya telah terkabulkan dan keinginannya pun telah tercapai maka harus melaksanakan upacara mappadottong tinjaq (memenuhi nazar) yaitu dengan cara mengadakan pertunjukan pakkacaping tommuane. 
Ada bebrapa acara yang termasuk mappadottong tinjaq diantaranya yaitu acara khatam quran, akikah, dan pernikahan. Adat ini sudah menjadi turun temurun dari zaman tradisional sampai zaman modern.

Pengertian tradisi "pakkacaping tommuane mandar" adalah salah satu adat istiadat kepercayaan masyarakat Mandar yang hanya dimainkan oleh laki-laki saja dan juga sebagai salah satu kesenian tradisi Mandar yang berkembang di Sulawesi Barat. Dalam bentuk pertunjukan seni pakkacaping yang menggunakan bahasa daerahnya sendiri dan memiliki arti yang bermakna dalam setiap kata perkata bagi masyarakat mandar.

Pakkacaping tommuaner ini diaggap sangat sakral bagi masyarakat Mandar karena syair-syair dan nada-nada lagu yang dimainkan memliki arti penting yaitu kepercayaan masyarakat Mandar yang menginginkan impian atau keinginan dan apabila doanya diijabah maka mereka melakukan salah satu ritual mappadottong tinjaq (bernazar) dengan menggelar pertunjukan pakkacaping.

Makna Ritual Pakkacaping Tommuane dalam Ritual Mappadotong Tinjaq. Tardisi tinjaq dan mappadotong tinjaq ini dalam masyarakat Mandar yaitu salah satu bentuk tradisi yang diwariskan secara turun temurun yang berbau Islam. Bagi orang mandar ritual Mappadotong Tinjaq ini adalah simbol kehidupan, salah satunya yaitu masa depan dan kebahagian, karena itu adat ini bisa dikatakan sangat sakral.

Realisasi tinjaq dalam masyarakat Mandar ini berbentuk macam-macam keinginan salah satu keinginan itu adalah khitan, khatam atau perkawinan.

Upacara Khatam bagi masyarakat mandar merupakan tuntutan agama dan ketentuan yang wajib ditempuh bagi setiap anggota masyarakat Mandar. Ini disebabkan khatam adalah sebuah persyaratan bagi setiap anggota masyarakat Mandar yang akan melaksanakan khitan dan ijab kabul dalam upacara pernikahan.

Dalam upacara khatam pada keluarga yang mampu setelah upacara khatam pada sore hari sering diselenggarakan karnaval sayyang pattuqduq (kuda menari). Orang-orang yang dikhatam 
didudukkan di atas sayyang pattuqduq dan diarak keliling desa. Pada malam harinya, selanjutnya diadakan seni pertunjukan pakkacaping yang dihadiri masyarakat setempat, kedudukan anak yang dikhatam dalam upacara ini adalah sebagai sentral upacara, sedangkan pertunjukan pakkacaping adalah sebagai inti dari mappadottong tinjaq.

Upacara khitan bagi masyarakat Islam di Mandar disebut massunnaq, dalam bahasa Mandar merupakan sebuah upacara yang wajib dilaksanakan untuk anak laki-laki. Biasanya upacara khitan tersebut dilaksanakan setelah anak laki-laki memasuki usia akil balig, yaitu antara 7-12 tahun. Secara kronologis tata upacara khitan di dalam masyarakat Mandar dilakukan dengan beberapa urutan tahapan seperti Mandoeq (mandi) yaitu anak yang akan dikhitan terlebih dahulu dimandikan oleh kedua orang tuanya, selanjutnya proses pelattigiang yaitu proses pewarnaan telapak tangan anak yang akan dikhitan dengan menggunakan daun lattigi atau innai (daun pacar) yang dilakukan oleh pukkali (pemuka agama) dan pappuangang (anggota hadat), kemudian proses nigesoq (pemotongan) yaitu upacara pemotongan ujung gigi dengan menggunakan batu tertentu, kemudian proses pemotongan kulit kulup (kulit kelamin).

Kemudian pada malam harinya biasanya diadakan seni pertunjukan pakkacaping yang dihadiri oleh seluruh lapisan masyarakat. Pada saat diadakan pertunjukan pakkacaping tersebut, kedudukan anak yang dikhitan sebagai sentral upacara sedangkan pertunjukan pakkacaping itu sendiri sebagai inti dari mappadottong tinjaq.

Upacara Pernikahan bagi masyarakat Mandar merupakan ketentuan adat dan agama yang wajib ditempuh atau dilaksanakan oleh setiap anggota masyarakat yang telah dewasa dan telah mampu. Oleh sebab itu pernikahan dalam masyarakat Mandar tidak hanya menyangkut seorang laki-laki ataupun seorang wanita, tapi melibatkan seluruh kerabat pihak laki-laki dan wanita. Secara kronologis tata upacara pernikahan di dalam masyarakat Mandar di terangkan sebagai berikut: Messisiq, yaitu terbentuk dari kata sisiq yang mendapatkan awalan "me" yang berarti menyelip. Acara 
messisiq merupakan sebuah penjajakan yang dilakukan pihak lakilaki terhadap pihak wanita.

Mambottui sorong, setelah lamaran dari pihak laki-laki disetujui oleh pihak wanita selanjutnya diadakan sebuah upacara yang disebut mambottui sorong. Secara harfiah ungkapan mambottui sorong adalah menetapkan mas kawin.

Maccandring, adalah suatu upacara penyerahan paccandrandringan (seserahan) yang telah diputuskan dalam upacara mambottui sorongdari pihak laki-laki ke pihak wanita. Selanjutnya proses akad nikah dan messita (saling mengunjungi keluarga kedua mempelai secara bergantian dengan membawa beberapa cindera mata).

Kemudian keesokan malamnya digelar pertunjukan pakkacaping sebagai pengukuhan ritual atau hiburan bagi keluarga dan seluruh lapisan masyarakat yang hadir.

Adapun makna-makna ritual yang terdapat di dalam upacara Mappadottong tinjaq tersebut antara lain sebagai berikut:

Dupa merupakan salah satu pelengkap di dalam ritual mappadottong tinjaq, sebab dengan dibakarnya dupa di dalam ritual mappadottong tinjaq maka itu merupakan pertanda dimulainya ritual mappadottong tinjaq tersebut, dupa adalah suatu benda yang dibakar sehingga menimbulkan aroma wangi semerbak di seluruh sudut ruangan tempat pelaksanaan ritual mappadottong tinjaq. Dengan wewangian yang tercium dari dupa yang terbakar diyakini dapat mengundang hadirnya malaikat dalam ritual mappadottong tinjaq tersebut dan dipercaya bahwa disetiap doa yang diucapkan akan lebih cepat tersampaikan kehadapan Tuhan melalui perantara melaikat yang hadir dan ikut serta mendoakan dan mengaminkannya.

Doa di dalam ritual mappadottong tinjaq merupakan hal yang tak bisa dipisahkan dari ritual tersebut, sebab semua yang dikehendaki di dalam hati akan mudah tersampaikan kepada Tuhan yang maha esa melalui suatu doa, dan di dalam ritual mappadottong tinjaq tersebut doa adalah suatu ungkapan permohonan dan terima kasih kepada Tuhan atas anugerah yang diberikan. 
Doa dilantunkan bersamaan dengan dibakarnya dupa, dan yang berdoa pada prosesi mappadottong tinjaq ini adalah orang yang melakukan hajatan (mappadottong tinjaq) sambil membakar dupa dilanjutkan dengan pembakaran dupa oleh pemain kecapi juga sambil mendoakan pemilik hajatan kemudian mengasapi instrument kecapinya dengan asap dupa dengan harapan permainan kecapi yang akan dipertontonkan setelahnya akan berjalan dengan lancar untuk melaksanakan fungsinya sebagai media (alat) yang dipakai dalam ritual mappadottong tinjaq.

Pada saat dilaksanakannya ritual mappadottong tinjaq ada juga tamu undangan yang secara sengaja "mattinjaq" atau bernadzar ingin juga melaksanakan pertunjukan pakkacaping tommuane, maka ia pun boleh ikut dalam ritual dan mengikatkan selembar kain, pita, benang, atau tali pada ujung ukiran kepala kecapi atau bagian lain dari kecapi dengan maksud mengikat janji dan akan dilepas ikatan tersebut ketika sudah terkabul keinginnya atau sudah dapat memenuhi janjinya (mappadottong tinjaq), dan pada saat itu pula pakkacaping selaku pemimpin doa segera mendoakan semoga keinginan orang yang mattinjaq bisa segera terlaksana.

Ayam sengaja dihadirkan di dalam ritual mappadottong tinjaq bertujuan akan diambil sedikit darahnya. Setelah acara berdoa, adapun maksud dari dihadirkannya ayam di dalam ritual mappadottong tinjaq tersebut menurut salah satu informan adalah sebagai symbol kelahiran, keselamatan dan penyucian diri, adapun diambil sedikit darahnya bertujuan untuk pengganti tubuh (passalle watang).

Pengambilan darah ayam dilakukan dengan cara mengiris sedikit bagian jengger ayam dan kemudian meneteskan sedikit darahnya di dalam wadah berupa piring yang sebelumnya diisi dengan tepung dan minyak kemudian dicampur dan digunakan untuk maccoqboq (memberi tanda di kening berupa titik).

Beras pada ritual mappadottong tinjaq merupakan simbol kehidupan, beras merupakan pelengkap dalam ritual mappadottong tinjaq sebab itu telah menjadi ketetapan turun-temurun, jumlah takaran menurut orang-orang yang pernah melakukan sebelumnya adalah berjumlah satu gantang (takar). 
Lagu Ritual, Masaqala dalam bahasa Mandar berarti persoalan atau "perihal". Nama atau istilah penyajian ini diambil sesuai dengan tema yang terdapat di dalam sajian paket masaqala, dimana cerita pada sajian tersebut berisikan persoalan-persoalan pemahaman substansi hubungan manusia dengan Tuhan. Lewat penyajian paket masaqala, penutur cerita menggunakan tasawuf sebagai bahan penutur cerita.

Interpretasi masyarakat terhadap pakkacaping tommuane dalam ritual mappadottong tinjaq. Pakkacaping tommuane merupakan suatu jenis pertunjukan tradisi yang sampai saat ini masih bertahan di Sulawesi Barat dan masih dapat kita jumpai di salah satu wilayah kecamatan di Sulawesi Barat tepatnya di kecamatan Tinambung. Pakkacaping tommuane ini masih sering dipentaskan pada beberapa ritual diantaranya ritual mappadottong tinjaq.

Bagi masyarakat Mandar pakkacaping tommuane memiliki arti tersendiri dan harus tetap dilestarikan sebab pakkacaping tommuane adalah salah satu dari beberapa jenis tradisi warisan leluhur serta menjadi karakter budaya Mandar.

Dari aspek bentuk pertunjukan pakkacaping tomuane mencerminkan nilai etika di dalam pertunjukannya dapat kita saksikan pakkacaping disaat memainkan kecapinya selalu mengenakan kostum yang sopan dan mencerminkan budaya kesopanan orang mandar serta lewat syair-syair yang dilantunkan selalu menggunakan bahasa-bahasa yang tidak menyinggung perasaan namun tetap memiliki makna yang dalam dari syair yang bertema kisah sejarah (toloq), sindiran (tedhe) serta syair yang bertema keagamaan.

Karena kegemaran masyarakat Mandar inilah sehingga pertunjukan pakkacaping tommuane selalu menjadi bagian dari tinjaq atau nadzar, karena dari niat yang baik maka akan terlahir pula sesuatu yang baik. Sehingga dengan alasan itu masyarakat Mandar memilih mengadakan pertunjukan pakkacaping tommuane sebagai pertunjukan yang dijanjikan ketika keinginnya terkabulkan.

Pakkacaping tommuane dinilai sebagai media yang baik untuk bersosialisasi, dakwah dan menginformasikan apa saja kepada 
masyarakat umum yang hadir menyaksikan, pesan-pesan yang disampaikan berupa pesan moral, keagamaan dan pesan social dapat disampaikan melalui media instrumen kecapi.

Pakkacaping tommuane dalam ritual mappadottong tinjaq adalah sebuah pertunjukan yang menjadi inti dari pada ritual mappadottong tinjaq, jika ber-tinjaq untuk mengadakan pertunjukan pakkacaping tommuane ketika doanya terkabul namun setelah doanya terkabul meskipun telah mengadakan ritual mappadottong tinjaq namu tak menghadirkan apa yang dijanjikan yaitu pertunjukan pakkacaping tommuane dalam ritualnya maka masyarakat meyakini akan mendapat balasan (musibah) dari Tuhan akibat tindakan ingkar janji tersebut, dan mereka meyakini akan bernasib sial jika tidak menjalankannya.

Jangan cepat ambil kesimpulan menilai suatu daerah dalam suatu tradisi yang menyebabkan akan membawa perubahan nilai ke masyarakat tersebut tetapi nilailah dari sudut pandang kacamata pelaku bahwa memiliki adat istiadat tersendiri yang sangat sakral dan sudah menjadi turun temurun dengan nilai-nilai keagamaan.

Kata pakkacaping berasal dari kata kacaping yang berarti kecapi dan mendapat awalan " $p a^{\prime \prime}$ yang di dalam bahasa Mandar termasuk awalan yang memuat makna profesi. Setelah kedua unsur tersebut itu di gabungkan maka terbentuk sisipan ' $K$ ' hingga terbentuklah kata pa-k-kacaping. Pakkacaping tommuane merupakan salah satu seni pertunjukan permainan kecapi yang dimainkan oleh laki-laki, dan juga sebagai salah satu kesenian tradisi Mandar yang berkembang di Sulawesi Barat. Hal ini diartikan bahwa pertunjukan pakkacaping merupakan seni pertunjukan yang berakar dan bersumber dari tata kehidupan masyarakat Mandar. Dalam penyajiannya pertunjukan Pakkacaping menggunakan bahasa lokal, yaitu bahasa Mandar dalam menuturkan cerita.

Bagi masyarakat Mandar pakkacaping tommuane memiliki arti tersendiri dan harus tetap dilestarikan sebab pakkacaping tommuane adalah salah satu dari beberapa jenis tradisi warisan leluhur serta menjadi karakter budaya Mandar.

Dari aspek bentuk pertunjukan pakkacaping tomuane mencerminkan nilai etika di dalam pertunjukannya dapat kita saksikan pakkacaping disaat memainkan kecapinya selalu 
mengenakan kostum yang sopan dan mencerminkan budaya kesopanan orang mandar serta lewat syair-syair yang dilantunkan selalu menggunakan bahasa-bahasa yang tidak menyinggung perasaan namun tetap memiliki makna yang dalam baik dari syair yang bertema kisah sejarah (toloq), sindiran (tedhe) serta syair yang bertema keagamaan. 


\section{Biodata Penulis}

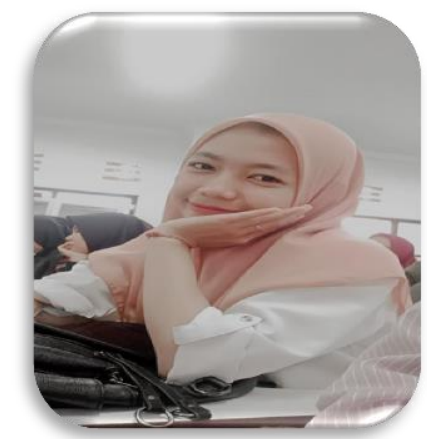

Fahriani, Alitta, 25 April 2000, Batulappa, kab.Pinrang. Prodi Jurnalistik Islam 


\section{Walasuji dalam Pernikahan Adat Bugis}

Sulawesi-Selatan merupakan salah satu daerah yang kaya dengan keanekaragaman budaya. Budaya tradisional yang bersifat ritual sampai dengan budaya tradisional yang bersifat hiburan. Sulawesi-Selatan dihuni oleh lebih empat rumpun suku bangsa yakni etnis Makassar, Bugis, Mandar, dan Toraja. Masing-masing memiliki gaya hidup dan cara hidup yang berbeda. Seperti halnya dalam melaksanakan suatu kegiatan upacara-upacara ritual kepercayaan, mereka tidak terlepas dari aturan adat yang juga masih dilengkapi penyembelihan hewan untuk persembahan kepada Maha Agung dan beberapa kegiatan sakral lainnya.

Khususnya pada adat Bugis-Makassar memiliki budaya walasuji yang cukup dikenal sebagai karakter orang Bugis Makassar. Selain itu masih ada lagi budaya yang tak lepas dari sebuah karya seni rupa yang kental dengan ciri khas Bugis-Makassar seperti misalnya Sarapo (Baruga), dan lamming. Walasuji bagi warga dan keturunan Bugis-makassar adalah bukan hal yang asing, walasuji dapat dijumpai dengan mudah di rumah-rumah warga Bugis yang pernah melakukan pesta pernikahan. Walasuji terbuat dari bambu. Bentuk motifnya segi empat atau (sulapa eppa).

Menurut almarhum Prof Dr Mattulada, budayawan Sulawesi Selatan yang juga guru besar Universitas Hasanuddin Makassar, konsep tersebut ditempatkan secara horisontal dengan dunia tengah. Masyarakat Bugis-Makassar memandang dunia sebagai sebuah kesempurnaan. Kesempurnaan yang dimaksud meliputi empat persegi penjuru mata angin, yaitu timur, barat, utara, dan selatan.

Wala Suji menggunakan pohon bambu, karena menurut sejarahnya pohon bambu dipercaya memiliki makna filosofi. Pohon bambu adalah sejenis tumbuhan yang sangat berguna bagi kehidupan manusia. Ada satu sisi dari pohon bambu dapat dijadikan bahan pembelajaran bermakna, yakni pada saat proses pertumbuhannya. Pohon bambu ketika awal pertumbuhannya atau sebelum memunculkan tunas dan daunnya terlebih dahulu 
menyempurnakan struktur akarnya. Akar yang menunjang ke dasar bumi membuat bambu menjadi sebatang pohon yang sangat kuat, lentur, dan tidak patah sekalipun ditiup angin kencang. Sebagai ruang lingkup kajian penulis secara khusus membahas mengenai asal usul walasuji, makna simbolik, fungsi, alat dan bahan, prosedur pembuatan, serta masalah yang dihadapi.

Istilah Wala Suji tidak asing lagi bagi orang Bugis. Jika Anda pernah mengunjungi acara adat atau perkawinan Kerabat orang Bugis, tentu anda akan melihat suatu Baruga (gerbang) yang dikenal dengan nama Wala Suji di depan pintu rumah mempelai atau yang melaksanakan hajatan. Wala Suji adalah anyaman bambu yang bermotif segi empat belah ketupat. Wala suji berasal dari kata wala, yang berarti pemisah/pagar/penjaga dan suji yang berharfiah putri. Wala Suji adalah sejenis pagar bambu dalam acara ritual yang berbentuk belah ketupat.

Mengapa Wala Suji harus menggunakan pohon bambu, karena pohon bambu dipercaya memiliki makna filosofi. Pohon bambu adalah sejenis tumbuhan yang sangat berguna bagi kehidupan manusia. Ada satu sisi dari pohon bambu dapat dijadikan bahan pembelajaran bermakna, yakni pada saat proses pertumbuhannya. Pohon bambu ketika awal pertumbuhannya atau sebelum memunculkan tunas dan daunnya terlebih dahulu menyempurnakan struktur akarnya. Akar yang menunjang ke dasar bumi membuat bambu menjadi sebatang pohon yang sangat kuat, lentur, dan tidak patah sekalipun ditiup angin kencang. hal tersebut mengajarkan kepada manusia agar tumbuh, berkembang dan mencapai kesempurnaan bergerak dari dalam ke luar, bukan sebaliknya. Lebih jauh memahami filosofi pohon bambu tersebut, bahwa menjadi apa sesungguhnya kita ini sangat tergantung pada pemahaman, penghayatan, dan pengamalan kita tentang "Keimanan kepada Allah SWT" yang terdapat dalam hati (qalbu) kita masingmasing.

Wala Suji ini merupakan cikal bakal tulisan lontara. Karena pada masa-masa itu belum ada yang namanya pulpen, pensil dan sejenis alat tulis lainnya. Huruf lontara ini pada awalnya dipakai untuk menulis tata aturan pemerintahan dan kemasyarakatan. Naskah ditulis pada daun lontar menggunakan lidi atau kalam yang 
terbuat dari ijuk kasar. Wala suji berasal dari kata wala yang artinya pemisah/pagar/penjaga dan suji yang berarti putri. Wala Suji adalah sejenis pagar bambu dalam acara ritual yang berbentuk belah ketupat. Sulapa eppa (empat sisi) adalah bentuk mistis kepercayaan Bugis-Makassar klasik yang menyimbolkan susunan semesta, api-airangin-tanah.

Sebenarnya konsep segi empat pada Wala Suji ini, berpangkal pada kebudayaan orang Bugis-Makassar yang memandang alam raya sebagai sulapaq eppaq wala suji (segi empat belah ketupat). Menurut almarhum Prof Dr Mattulada, budayawan Sulawesi Selatan yang juga guru besar Universitas Hasanuddin, Makassar, konsep tersebut ditempatkan secara horizontal dengan dunia tengah.

Dengan pandangan ini, masyarakat Bugis-Makassar memandang dunia sebagai sebuah kesempurnaan. Kesempurnaan yang dimaksud meliputi empat persegi penjuru mata angin, yaitu timur, barat, utara, dan selatan. Secara makro, alam semesta adalah satu kesatuan yang tertuang dalam sebuah simbol aksara BugisMakassar, yaitu 'sa' yang berarti seua, artinya tunggal atau esa. Begitu pula secara mikro, manusia adalah sebuah kesatuan yang diwujudkan dalam sulapaq eppaq. Berawal dari mulut manusia segala sesuatu dinyatakan, bunyi ke kata, kata ke perbuatan, dan perbuatan mewujudkan jati diri manusia. Dengan demikian, wala suji dalam dunia ini, dipakai sebagai acuan untuk mengukur tingkat kesempurnaan yang dimiliki seseorang. Kesempurnaan yang dimaksud itu adalah kabaraniang (keberanian), akkarungeng (kebangsawanan), asugireng (kekayaan), dan akkessingeng (ketampanan/kecantikan).

Bagi masyarakat Bugis-Makassar, wala suji, dipakai sebagai acuan untuk mengukur tingkat kesempurnaan yang dimiliki seseorang. Kesempurnaan yang dimaksud itu adalah keberanian, kebangsawanan, kekayaan, dan ketampanan atau kecantikan. Jika anda pernah mengunjungi acara perkawinan suku Bugis-Makassar, tentu anda akan melihat suatu baruga (gerbang) yang dikenal dengan nama wala suji di depan pintu rumah mempelai.

Bentuk wala suji seperti gapura dan menyerupai bagian depan rumah panggung suku Bugis-Makassar. Atapnya berbentuk segitiga 
dan disangga oleh rangkaian anyaman bambu. Sebagai penghias, tak lupa diberi janur kuning. wala suji adalah sejenis pagar bambu dalam acara ritual yang berbentuk belah ketupat. Sulapa eppa (empat sisi) adalah bentuk mistis kepercayaan Bugis-Makassar klasik yang menyimbolkan susunan semesta, api-air-angin-tanah.

Dalam prosesi membuat walasuji biasanya dibuat satu sampai dua minggu sebelum acara pesta pernikahan suku bugis-makassar, tergantung seberapa besar strata sosial yang ada pada keluarga yang akan membuat pesta Menurut Mappeasse Gule salah seorang pemerhati kebudayawan di Bone. Orang yang membuatnyapun tidak terbatas mulai dari satu orang sampai puluhan, awalnya walasuji dibuat dari beberapa batang pohon dan sebaiknya walasuji dibuat dari bambu tua yang berkwalitas baik, lurus dan masih biru.

Menurut Mappeasse tugas-tugas di atas tidak selamanya berjalan seperti itu tergantung seberapa besar pengalaman orang yang membuat walasuji, serta motif walasujipun sangat berfariasi seperti walasuji dengan bentuk segi empat besar dan segi empat kecil, dan yang segi empat kecil biasanya dibuat oleh kalangan profesional dan dikhususkan kepada strata yang lebih diatas sementara yang besar diperuntukkan bagi kalangan menengah dan pembuatannya tidak terlalu sulit dan lama

Masalah yang dihadapi dan pergeseran fungsi dewasa ini, wala suji bukan suatu hal yang langka lagi, karena bisa dilihat walaupun tidak ada acara perkawinan. Sejatinya, wala suji hanya dipakai pada acara pernikahan atau pesta adat bagi warga Sulawesi Selatan yang masih memegang teguh adat setempat. Namun kini, wala suji telah menjadi gerbang permanen bagi rumah-rumah keturunan bangsawan lokal. Bahkan pada beberapa keluarga yang pernah melakukan pesta perkawinan, membiarkan wala suji itu tetap berdiri kukuh dalam waktu lama. Padahal semestinya, maksimal digunakan hingga 40 hari pasca perkawinan atau pesta adat.

Keengganan merubuhkan wala suji usai upacara perkawinan itu, selain merasa sayang menghancurkan bangunan mini itu karena harga pembuatannya yang mencapai ratusan ribu rupiah, wala suji dapat pula difungsikan sebagai tempat bernaung dari panasnya matahari atau derasnya hujan pada musim penghujan. Sebagian orang yang memiliki wala suji ini, justru membuat bangku panjang 
dari bambu atau kayu di sisi kiri dan kanan bagian bawah wala suji, sebagai tempat bersantai. Bahkan sejumlah restoran atau hotel-hotel berbintang di Makassar, juga memasang wala suji di lokasi prasmanan atau tempat sajian hidangan dengan alasan menambahkan estetika dekorasi ruangan, sekaligus memperkenalkan salah satu karya seni budaya masyarakat Sulawesi Selatan.

Wala suji merupakan karya seni rupa anyaman yang khas bagi orang Bugis-Makassar. Saat ini bukan lagi murupakan milik bagi keluarga bangsawan bugis makassar, siapapun bisa menggunakan wala suji dalam dalam mengadakan sebuah kegiatan. Baik itu pesta pernikahan, peringatan hari lahir, perhiasan rumah-rumah makan, restoran, hotel, pagar rumah, rumah peristirahatan serta untuk sesajen (persembahan), dan ada kecenderungan wala suji menjadi sebuah karya seni rupa sebagai penghias. namun terlepas dari semua itu walasuji tetap menyimbolkan budaya lokal bugis makassar yang sifatnya berkembang dan tak akan terlupakan sampai kapanpun. 


\section{Biodata Penulis}

MUHAMMAD ALI IMRAN SYAFRIL. TEMPAT,TANGGAL LAHIR : BENTENG GALUNG, 21 APRIL 1999 ALAMAT BENTENG GALUNG PENDIDIKAN TK TPA NURUL IQTIHAT SDN 132 PATAMPANUA. SMPN 2 PATAMPANUA. SMK BARAMMULI. IAIN PAREPARE

MOTTO HIDUP:

"Tak perlu sukses cukup jadi orang yang berguna" 


\section{Suku Bugis Surganya Pamali}

Pemmali merupakan istilah dalam masyarakat Bugis yang digunakan untuk menyatakan larangan kepada seseorang yang berbuat dan mengatakan sesuatu yang tidak sesuai. Pemmali dalam bahasa Indonesia diterjemahkan menjadi 'pamali', yang memiliki makna pantangan, berdasarkan adat dan kebiasaan. Masyarakat Bugis meyakini bahwa pelanggaran terhadap pemmali akan mengakibatkan ganjaran atau kutukan. Kepercayaan masyarakat Bugis terhadap pemmali selalu dipegang teguh. Fungsi utama pemmali adalah sebagai pegangan untuk membentuk pribadi luhur.

Dalam hal ini, pemmali memegang peranan sebagai media pendidikan budi pekerti. Pemmali biasanya dituturkan oeh orang tua kepada anak, kakak kepada adiknya, suami kepada istrinya, dan sebagainya. Pemmali muncul atau dituturkan apabila seseorang melakukan sesuatu yang tidak sesuai dengan adat, dianggap melanggar etika, dan perubahan lain yang dianggap tidak pantas.

Masyarakat Bugis menggunkan pemmali sebagai pengendalian diri dalam bertindak. Pemmali diwariskan secara turun temurun akibat adanya pengalaman masa lalu dan kebiasaan-kebiasaan yang dihubungkan dengan kejadian yang menimpanya. Meskipun kejadian yang alami terjadi hanya karena kebetulan saja, tetapi diyakini sebagai ganjaran atas pelanggaran terhadap pemmali.

Pemmali sebagai kebiasaan yang dituturkan dari mulut ke mulut hanya akan bertahan seiring eksistensi masyarakat Bugis. Saat ini muncul kekhawatiran akan eksistensi pemali. Hal tersebut disebabkan kurangnya minat masyarakat, khususnya generasi muda Bugis untuk mendalami, menjaga, dan memahami nilai yang terkandung dalam pemmali. Permasalahan lan adalah tidak terdokumentasinya secara baik pemmali yang ada dalam masyarakat Bugis.

Melihat siklus perkembangannya, kepercayaan tentang pemmali yang selama ini hidup dan perkembang dimasyarakat Bugis berangsur-angsur menghilang, seiring dengan arus modernisasi. 
Kepercayaan seperti itu semenjak zaman nenek moyang diyakini masyarakat bahwa bila melanggar aturan pemali bisa terkena imbasnya atau ganjaran dari perbuatan yang telah dilanggarnya. Apakah imbasnya itu berupa penyakit gatal-gatal, sakit perut, sakit kepala, atau sampai-sampai sulit mendapatkan rezeki bahkan jodoh dan sebagainya

"Pammali sangat bagus dan baik, karena ini adalah budaya atau adat istiadat nenek moyang terdahulu yang dimana nilai-nilai keagamaan, nilai-nilai kebaikan yang selalu dicantumkan di dalamnya. Akan tetapi, sekarang ini pamali itu banyak disalahgunakan atau banyak banyak yang salah paham, bahkan dengan adanya pamali ini mereka berlebih-lebihan yang akhirnya akan terjerumus kepada kemusyrikan, sehingga hilanglah nilai pamali sesungguhnya yang diajarkan oleh orang tua atau nenek moyang terdahulu. Pamali ini berisi tentang hal-hal yang tidak boleh atau tidak mesti kita lakukan, karena dapat mencelakakan diri kita atau orang lain". (Wawancara Informan)

Pemmali yang dalam bahasa Indonesia dipersepsikan dengan istilah pemali bukanlah istilah tunggal yang digunakan masyarakat tradisional untuk menamai kumpulan pantangan dan larangan adatnya, sebab pada setiap wilayah di Indonesia memiliki bahasa yang sangat beragam, tetapi makna pemali tetap diakui eksistensinya dan disebut sesuai dengan bahasa setempat. Di Sulawesi Selatan, pemali tidak saja dikenal dan diyakini oleh dua suku, tetapi juga dikenal oleh semua suku yang ada. Selain suku Bugis dan Makassar, suku besar lainnya adalah Mandar dan Toraja.

Suku Bugis dan Makassar sebagai penduduk mayoritas Sulawesi Selatan menyebut pemali secara berbeda. Dalam masyarakat Bugis, pemali dikenal dengan istilah pemmali, semantara dalam masyarakat Makassar dikenal dengan istilah kasipalli selain istilah pemmali itu sendiri. Sekalipun berbeda istilah, keduanya digunakan untuk menyatakan larangan atau pantangan terhadap seseorang dan masyarakat untuk melakukan atau mengatakan sesuatu yang tidak sesuai dengan keyakinan dan nilai adat dan tradisi yang diwarisi dari nenek moyang. Mereka meyakini bahwa pelanggaran terhadap pemali akan mengakibatkan ganjaran atau kutukan, dan keyakinan tersebut selalu dipegang teguh. 
Sebagai suatu tradisi yang turun temurun, pemmali atau kasipalli mengandung ajaran akan nilai dan falsafah hidup yang menjadi pegangan para leluhur. Pemali dalam hal ini memegang peranan sebagai media pemeliharaan dan pelestarian nilai atau apa yang dianggap nilai. Salah satu sumber nilai yang utama dalam kebudayaan Bugis yang kemudian dialihkan secara turun-temurun dari satu generasi ke generasi berikutnya adalah paseng atau pappangaja.

Paseng bersama dengan pappangaja itu termaktub di dalam lontara"-lontara" dalam rangka pewarisan nilai-nilai dasar kebudayaan masyarakat Bugis-Makassar. Paseng berarti nasehat dan petaruh atau dengan arti wasiat yang dipertaruhkan. Ia menekankan tentang keharusan dan pantangan. Dengan demikian, pemmali atau kasipalli bagian dari paseng/pasang yang pantang untuk dilanggar. dengan ucapan natabai pappasang/nakennai pappaseng artinya sudah ditimpa salah satu isi pesan. Sedangkan orang yang melanggar pantangan disebut pasek (orang sial).

Pemali dalam masyarakat Bugis dan Makassar tidak berdiri sendiri, tetapi beriringan dengan pappangaja (dakwah/ajakan) dan paseng (nasehat). Pemali digunakan sebagai bagian dari upaya menguatkan terpenuhinya pappangaja dan terlaksananya paseng. Sebagai mana disebutkan sebelumnya, paseng berarti nasehat dan petaruh atau dengan arti wasiat yang dipertaruhkan dan menekankan tentang keharusan dan pantangan.

Di antara bentuk pemali yang memuat ajaran moralitas adalah: 1) Bangun terlambat atau bermalas-malasan, karena dipercayai rejekinya pada hari itu hilang. 2) Berlama-lama mandi bagi anak muda, suatu saat nanti mendapat pasangan yang tua (berumur) . 3) Bersendawa di depan orang banyak, agar tidak dinilai kurang sopan oleh orang lain. 4) Duduk di depan pintu, karena akan menghalangi rezeki. 5) Duduk di jalan atau pintu bagi orang hamil, karena mengakibatkan anak yang ada di dalam perut teringgal di pintu (sulit) saat melahirkan. 6) Keluar rumah menjelang magrib, karena akan dpengaruhi oleh setan. 7) Makan berpindah-pindah tempat, karena akan sering menikah (kawin cerai). 8) Makan dan minum menggunakan penutup, karena akan dijadikan penutup malu 
orang lain. 9) Memukul dengan sapu lidih, nanti tidak menikah. 10) Menduduki bantal (tudangi angkalulung), nanti akan terkena bisul.

Pemali-pemali di atas merupakan bentuk dan upaya pelarangan dan pencegahan (nahi) terhadap segala hal yang dianggap terlarang atau tercela (munkar). Pada saat yang sama mengandung nilai edukatif dan moralitas dalam rangka pembentukan karakter di samping membangun etos kerja. Hal itu bermanfaat dalam menguatkan pangadereng, juga berperan dalam pengelolaan ekonomi keluarga dan masyarakat. Pemali-pemali dimaksudkan untuk menanamkan kedisiplinan, kamandirian, dan bekal etika atau moralitas. Semua nilai baik itu sesungguhnya merupakan hal-hal ma“ruf (kebajikan) yang menjadi fungsi dakwah Islam.

Masyarakat Bugis dan Makassar idealnya mampu mewujudkan tujuan pokok hukum Islam dengan memaksimalkan potensi paseng dalam mengajak, menanamkan, dan mendidik anak-anak mengenai moralitas dan etos kerja (konstruktif), dan menjalankan peran pemali dalam hal pencegahan segala hal yang dekonstruktif.

Pammali menjadi bagian adat-istiadat yang selalu berada dalam ingatan masyarakat dulu sampai sekarang. Meskipun sering terlupakan oleh sebagian orang dan dianggap mitos namun di dalam tradisi lisan pammali terdapat hal positif yang berguna bagi kehidupan manusia baik dari segi tuturan kata maupun tingkah lakunya. Masyarakat Bugis, pammali sebagai perangkat norma yang berfungsi mengatur dan mengendalikan serta memberi arah setiap tindakan dan perbuatan manusia. Di kalangan penduduk masih banyak terdapat kepercayaan yang diwujudkan dalam bentuk pammali atau pantangan, baik dalam pekerjaan maupun dalam pengungkapan.

Pammali yang berfungsi sebagai control sosial bagi seseorang dalam berkata, bertindak atau melakukan suatu kegiatan. Pammali terkait erat dengan pappaseng (pesan, nasehat, wasiat) oleh pengguna bahasa/penutur, setinggi apapun pappaseng (pesan) tersebut merupakan nasehat hidup atau hikmah yang lahir dari penjelajahan hidup yang disampaikan lewat karya sastra dan merupakan salah satu nilai ekspresi budaya suku Bugis. Pammali juga sebagai sebuah pesan yang memberi efek dan pelanggaran 
yang sangat menekan, sebab diikuti dengan sanksi meskipun bentuknya ada yang bersifat gaib.

Menurut Soekanto (2007:179) kontrol sosial dapat diartikan sebagai pengendalian sosial yang sifatnya mendidik, mengajak, atau bahkan memaksa masyarakat mematuhi kaidah dan nilai sosial yang berlaku. Dengan tujuan untuk mencapai keserasian antara stabilitas dengan perubahan-perubahan dalam masyarakat. Adapun pendapat lain Kontrol sosial (Hirschi, Wiatroswki dkk, 1981), Eny Purwandari (2011: 32-33) menyebutkan adanya peran mikro sistem di dalam pembentukan delinquency anak. Asumsi teori ini adalah koneksi sosial antara anak dengan keluarga, teman sekolah, dan lingkungan sosial lainnya. Kontrol sosial Hirschi menyebutkan empat elemen social bond yaitu:

Pertama, attachment atau Kelekatan. Kelekatan merupakan faktor emosi, hal ini mendeskripsikan bahwa anak memiliki kecendrungan untuk melekatkan diri pada orang lain. Anak melakukan kelekatan pada orang tua, sekolah dan teman sebayanya. Di dalamnya termasuk supervisi orangtua, kualitas komunikasi, kebersamaan, pemahaman orangtua tentang pertemanan anaknya dan kepercayaan. Jika kelekatan anak kuat terhadap pihak tertentu, hal ini akan membentuk suatu komitmen.

Kedua, commitment atau Komitmen terhadap aturan. Komitmen merupakan komponen rasional dari suatu ikatan, hal ini mengacu pada sejauh mana anak-anak terlibat dalam kegiatan konvensional suatu kelompok. Komitmen seorang dengan tidak melakukan suatu tindakan pelanggaran dikarenakan mereka tahu mendapatkan masalah akan menghambat kesempatan mereka untuk menjadi sukses. Hal ini dapat terbentuk jika ada dalam kelompok dimana anak melekat dirinya. Contohnya seperti menghormati tradisi, dan percaya pada norma-norma dan nilai-nilai hidup yang berlaku dimasyarakat.

Ketiga, involment atau keterlibatan. Keterlibatan anak berhubungan dengan seberapa banyak waktu yang dihabiskan seorang anak untuk berinteraksi dengan individu lain dalam suatu kegiatan. Jika suatu interaksi yang tepat dengan kegiatan maupun seseorang, seperti olahraga, kesenian dan lainnya merupakan 
kegiatan yang secara dominan dilakukan anak maka kemungkinan melakukan perilaku nakal akan semakin kecil. Namun sebaliknya, jika interaksi dan kegiatan yang kurang tepat seperti bolos, tawuran, melawan orangtua, mencuri dan lainnya merupakan hal yang sering dilakukan anak maka kenakalan pun akan semakin mudah terbentuk dalam diri anak.

Keempat, belief atau Keyakinan. Keyakinan yaitu kesediaan dengan penuh kesadaran untuk menerima segala aturan. Keyakinan dalam diri moral dari norma konvensional merupakan komponen keempat dari ikatan sosial. Beberapa anak memiliki keyakinan yang lebih kuat dalam mengikatkan diri dalam aturan sosial, sehingga tidak cendrung berkomitmen terhadap kenakalan. (http://repository.umrah.ac.id)

Pemmali merupakan istilah dalam masyarakat Bugis yang digunakan untuk menyatakan larangan kepada seseorang yang berbuat dan mengatakan sesuatu yang tidak sesuai. Pemmali dalam bahasa Indonesia diterjemahkan menjadi 'pamali', yang memiliki makna pantangan, berdasarkan adat dan kebiasaan. Pammali menjadi bagian adat-istiadat yang selalu berada dalam ingatan masyarakat dulu sampai sekarang. Meskipun sering terlupakan oleh sebagian orang dan dianggap mitos namun di dalam tradisi lisan pammali terdapat hal positif yang berguna bagi kehidupan manusia baik dari segi tuturan kata maupun tingkah lakunya. Masyarakat Bugis, pammali sebagai perangkat norma yang berfungsi mengatur dan mengendalikan serta memberi arah setiap tindakan dan perbuatan manusia.

Sekiranya kita bisa mengaitkan pammali kepada nilai-nilai keagamaan, sehingga pammali itu tidak diartikan lagi dengan kemusyrikan atau jauh dari kata kemusyrikan, akan tetapi pammali itu mendekatkan kepada mengikuti ajaran sunnah-sunnah Rasulullah saw. 


\section{Biodata Penulis}

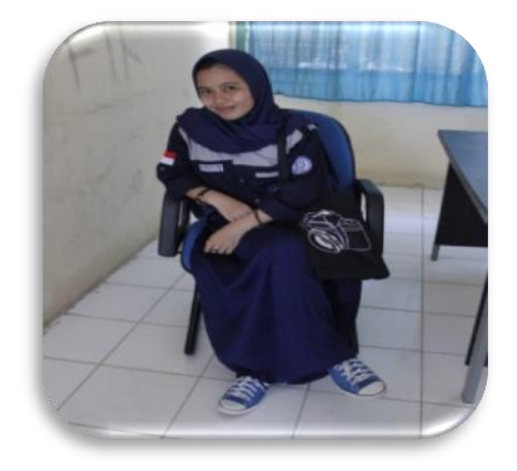

Rusni, lahir di Kandoka tanggal 29 Oktober 2000. Anak kedua dari empat bersaudara. Lahir dari pasangan Rusli (Ayah) dan Hanawia (Ibu). Penulis menempuh pendidikan di SD 270 Kandoka, kemudian melanjutkan pendidikan di SMPN Pasang, dan kemudian di SMKN Paku, hingga akhirnya menempuh pendidikan ke jenjang yang lebih tinggi yakni di Institut Agama Islam Negeri (IAIN) Parepare Fakultas Ushuluddin Adab dan Dakwah (FUAD) dan mengambil Prodi Jurnalistik Islam (JI).

Penulis masih melanjutkan pendidikan saat ini dan sudah memasuki semester IV dan ini merupakan proposal pertama yang dibuat pada mata kuliah Studi Budaya Lokal.

Motto :

"ubah pikiran mu dan kau dapat mengubah duniamu" 


\section{Budaya Mappatabe'di Kalangan Masyarakat}

Perkembangan teknologi mengubah perilaku masyarakat saat ini, kita dapat membaca diberbagai media maupun riset yang menyataan bahwa teknologi telah mengubah perilaku masyarakat. Salah satunya adalah perilaku mappatabe. Salah satu tradisi yang kini mulai punah yakni tradisi mappatabe'. Kata tabe' itu sendiri merupakan istilah yang bermakna sopan yang biasa juga digunakan dalam berkomunikasi antara anak terhadap orang yang lebih tuanya. Jadi budaya tabe' sebenarnya memberikan efek terhadap pembentukan karakter anak dan sangat tepat untuk diterapkan dalam kehidupan sehari-hari karena budaya tersebut mengajarkan bagaimana anak berperilaku atau bertata krama yang baik terhadap orang lain dan berakhlak dengan sesama.

Tradisi mappatabe' merupakan suatu kebiasaan yang dilakukan oleh masyarakat bugis yang menggambarkan adat sopan santun atau tingkah laku yang berarti "permisi". Sebagai gambaran, tradisi ini dilakukan untuk memberikan rasa hormat terhadap orang yang lebih tua, misalnya ketika berjalan di depan orang tua, maka diucapkanlah kata tabe'sebagai permintaan maaf dibarengi dengan sikap tunduk dan menggerakkan tangan ke bawaah bahkan hingga badan membungkuk. Perilaku seperti itulah yang dijadikan sebagai salah satu indikator oleh masyarakat bugis sehingga seorang anak dikatakan sopan dan santun.

Adat mappatabe' tabe' merupakan suatu adat yang dimiliki oleh masyarakat Sulawesi-selatan, khususnya masyarakat suku bugis. Adat ini mengajarkan perilaku sopan santu dan sikap hormat kepada orang yang lebih tua. Makna yang terkandung dalam budaya mappatabe' dilihat dari segi maknanya, adat mappatabe' ini memiliki makna yang cukup mendalam. Pertama kata tabe merupakan simbol dari upaya menghargai dan menghormati terhadap sesama dan tidak boleh berbuat seenak hati. Kedua, adat mappatabe' merupakan perwujudan dari sikap Taro Ada Taro Gau, yaitu keselarasan antara perkataan dan perbuatan. Makna lain dari budaya attabe' adalah 
satunya kata dan perbutan (taro ada taro gau), bahwa orang bugis Makassar dalam kehidupan sehari-hari harus berbuat sesuai dengan perkataan.

Sikap tabe' adalah serupa dengan sikap mohon ijin atau permohonan permisi ketika hendak melewati orang-orang yang sedang duduk berjajar terutama bila yang di lewati adalah orang orang yang usianya lebih tua atau di tuakan. Sikap tabe' di maksudkan sebagai penghormatan kepada orang lain yang mungkin saja akan terganggu akibat kita meskipun kita tidak bermaksud demikian.

Budaya attabe' sesungguhnya sangat tepat diterapkan dalam kehidupan sehari hari, terutama dalam mendidik anak dengan mengajarkan hal-hal yang berhubungan dengan akhlak sesama, mengucap iye' jika menjawab pertanyaan sebelum mengutarakan alasan, ramah, dan menghargai orang yang lebih tua dan menyayangi yang muda. Inilah diantaranya ajaran-ajaran suku bugis Makassar sesungguhnya yang termuat dalam lontara' yang harus direalisasikan dalam kehidupan sehari-hari (http://asmiatiputri.blogspot.com)

Nilai kearifan lokal dalam tradisi mappatabe'. Adat ini juga mengandung nilai-nilai luhur yang diharapkan dapat menghasilkan insan-insan yang berbudaya dan bermoral. Nilai-nilai tersebut dikenal dengan istilah falsafah 3 S yaitu: a. Sipakatau : mengakui segala hak tanpa memandang status sosial atau rasa kepedulian terhadap sesama. b. Sipakalabbirl : sikap hormat terhadap sesama dan senantiasa memperlakukan orang dengan baik. c. Sipakainga': tuntunan bagi masyarakat bugis untuk saling mengingatkan. (http://andikiilawati.blogspot.com) Itulah kearifan lokal yang dimiliki oleh masyarakat bugis, sangat sederana namun memiliki makna yang sangat mendalam yaitu sikap saling menghormati antar sesama manusia.

Budaya tabe ini merupakan nilai luhur yang sangat tinggi sehingga harus dilestarikan untuk menopang kehidupan yang lebih baik. Budaya ini juga sangat baik diterapkan di kalangan anak muda untuk melatih atau mengajarkan kepada mereka cara bertatakrama 
yang baik, cara sopan santun dan cara menghargai antar sesama manusia.

Budaya tabe merupakan symbol dari budaya yang menghargai dan menghormati siapapun, tidak boleh berbuat semenah menah atau sesuka hati. Penerapan tabe dalam kehidupan masyarakat bugis yaitu misalnya menyeret sandal atau kaki, tetapi dengan mengucap salam atau menyapa dengan sopan, sikap tabe juga merupakan permohonan untuk melintas. Tabe merupakan tindakan untuk tidak berkacak pinggang, dan tidak usil mengganggu orang lain (http://andikiilawati.blogspot.com)

Lunturnya tradisi mappatabe' di kalangan milenial. Tabe' (permisi) merupakan budaya yang indah yang ditinggalkan oleh leluhur, yang mewariskan sopan santun yang tidak hanya melalui ucapan tetapi juga dengan tindakan. Realita saat ini adalah budaya tabe'perlahan-lahan telah luntur dalam masyarakat, khususnya pada kalangan anak-anak dan remaja. Mereka tidak lagi memiliki sikap tabe' dalam dirinya. Entah karena orang tua yang tidak mengajarkannya dari kecil atau karena terkontaminasi oleh budaya luar atau budaya barat yang mampu menghilangkan budaya tabe' tersebut.

Beberapa teori yang dapat digunakan dalam cultural studies sebagaimana yang dikumpulkan oleh Akhyar Yusuf Lubis dalam buku "Dekonstruksi Epistemologi Modern", diantaranya adalah:

a. Semiotika (Roland Barthes) teori ini memahami aspek budaya melalui semiotika, dengan melihat budaya sebagai tanda. Teori ini digunakan dalam penelitian yang bersifat local, etnis dan subkultur.

b. Habitus (Pierre Bourdieu) Habitus adalah struktur mental atau kognitif, yang digunakan aktor untuk menghadapi kehidupan sosial budaya. Atau, dalam pengertian Ritzer, yang dikutip Lubis, habitus adalah konstruksi dunia sosial, struktur sosial yang diinternalisasikan dan diwujudkan. Ia mencerminkan posisi sosial,kebiasaan yang terdapat pada kelas atau kelompok sosial.

c. Teori Industri Budaya (Walter Benyamin) Teori ini memandang industri budaya sebagai produksi mekanis budaya yang disebarluaskan melalui media cetak dan elektronik. 
d. Teori Hegemoni (Antonio Gramsci) Teori ini berfokus pada kajian tentang negosiasi penguasa dengan kelompok budaya tandingan menuju landasan budaya dan ideologi yang bisa membuatnya mendapatkan posisi kepemimpinan. Hegemoni adalah upaya bagaimana kelompok penguasa dapat mensubordinasi dan tetap dapat mempertahankan status quo.

e. Teori Pendidikan Kritis (Paulo Freire) Teori ini, yang merupakan cultural studies di bidang pendidikan, mengritik model pendidikan yang disebutnya sebagai bergaya bank. Teori ini berpengaruh besar pada dunia pendidikan. (http://diskursusnusantara.blogspot.com)

Teori yang digunakan ini adalah teori semiotika, karena berfokus pada budaya lokal di daerah Sulawesi-selatan khususnya di suku bugis. Tradisi mappatabe' merupakan suatu kebiasaan yang dilakukan oleh masyarakat bugis yang menggambarkan adat sopan santun atau tingkah laku yang berarti "permisi" sikap tabe' serupa dengan sikap mohon ijin atau permohonan permisi ketika hendak melewati orang orang yang sedang duduk berjajar terutama bila yang di lewati adalah orang-orang yang usianya lebih tua atau di tuakan. Sikap tabe' dimaksudkan sebagai penghormatan kepada orang lain yang mungkin saja akan tergangu akibat kita meskipun kita tidak bermaksud demikian.

Budaya tabe ini merupakan nilai luhur yang sangat tinggi sehingga harus dilestarikan untuk menopang kehidupan yang lebih baik. Budaya ini juga sangat baik diterapkan di kalangan anak muda untuk melatih atau mengajarkan kepada mereka cara bertatakrama yang baik, cara sopan santun dan cara menghargai antar sesama manusia. Budaya tabe' perlu dilestarikan di kalangan anak-anak supaya budaya tabe' tidak hilang di masa yang akan datang. Mengajarkan tabe'pada masa dini sangat bagus untuk mengajarkan cara bertatakrama yang baik dan cara sopan santun terhadap sesama. 


\section{Biodata Penulis}

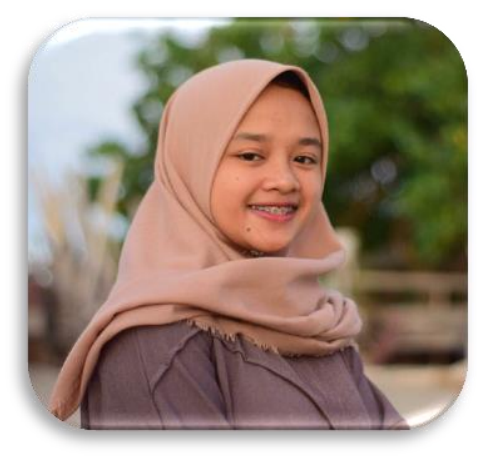

Sri Wulandari, lahir di Rantelemo tanggal 02 mei tahun 2000. Anak pertama dari empat bersaudara. Penulis lahir dari keluarga sederhana dari pasangan Jumain (ayah) dan Nurhayati (ibu). Penulis tinggal di dusun Rantelemo, desa Latimojong, kecamatan Buntu Batu, kabupaten Enrekang. Penulis menempuh pendidikan formal di mulai dari SDN 77 Rantelemo, kemudiaan SMP Negeri Satap 5 Baraka, lalu melanjutkannya di Madrasah Aliyah Negeri Enrekang hingga akhirnya mampu menempuh pendidikan ke jenjang yang lebih tinggi yakni di Institut Agama Islam Negeri (IAIN) Parepare Fakultas Ushuluddin Adab \& Dakwah ( FUAD). Saat ini penulis masih menempuh pendidikan di program Studi Jurnalistik Islam semester IV

Motto: "segala sesuatu, mulailah dengan membaca basmalah" 


\section{Tradisi Mappadendang Suku Bugis}

Indonesia memiliki lebih dari 300 kelompok etnik atau suku bangsa, lebih tepatnya terdapat 1.340 suku bangsa di Tanah Air menurut sensus BPS (Badan Pusat Statistik) tahun 2010. Diantaranya adalah Suku Bugis yang berada di Sulawesi Selatan. Suku Bugis mempunyai keunikannya tersendiri dibandingkan suku-suku lain yang ada di Indonesia.

Suku Bugis memiliki kebudayaan yang unik yang tetap eksis di zaman milenial seperti sekarang ini. Meskipun zaman semakin modern, kebudayaan suku ini tetap menjadi sorotan yang menarik untuk ditelusuri lebih jauh lagi keunikan-keunikannya. Salah-satu hal unik yang dimilikinya adalah tradisi Mappadendang.

Mappadendang atau yang lebih dikenal dengan sebutan pesta pasca panen pada suku bugis merupakan syukuran atau pesta syukur atas keberhasilannya dalam menanam padi kepada yang maha kuasa. Mappadendang sendiri merupakan suatu pesta yang biasanya diadakan dalam skala besar.

Tetapi ada juga yang melakukannya hanya dengan kerabat saja tanpa melibatkan orang lain dengan skala yang lebih kecil. Mappadendang dilakukan dengan cara menumbuk gabah pada lesung dengan tongkat besar sebagai penumbuknya, orang-orang akan beramai-ramai berkumpul di suatu tempat untuk melakukan penumbukan gabah secara bersama.

Mappadendang bukan hanya mengenai pesta pasca panen tapi juga memiliki nilai magis tersendiri. Disebut juga sebagai pensucian gabah yang dalam masih terikat dengan batangnya dan terhubung dengan tanah menjadi ase (beras) yang nantinya akan menyatu dengan manusianya. Olehnya perlu dilakukan pensucian agar lebih berberkah. (https://id.wikipedia.org/wiki)

Mungkin tradisi Mappadendang ini sering dilakukan pada masa nenek kita, yang artinya pada zaman sekarang Mappadendang ini sudah jarang ditemui. Mengapa hal tersebut bisa terjadi? "Suku bugis setiap kali musim panen padi telah tiba sudah ada tradisi 
Mappadendang sebagai ungkapan kebahagiaan dan rasa syukur atas hasil panennya tapi masyarakat bugis mulai meninggalkan tradisi Mappadendang, mungkin karena Mappadendang sudah dianggap tradisi nenek moyang dan sekarang masyarakat sudah tersentuh modernisasi." Ungkap informan".

Dalam budaya suku Bugis Makassar, salah satu budaya atau ritual yang rutin dilakukan setiap tahun dalam kegiatan pertanian (panen) yaitu Mappadendang, yang diikuti seluruh petani. Ritual ini dilakukan sebagai bentuk suka cita dan kesyukuran pada Sang Khalik, untuk hasil panen pertanian yang melimpah. Selain bentuk suka cita, ritual Mappadendang juga dimaksudkan untuk mempertahankan warisan budaya leluhur.

Mappadendang di Kabupaten Pinrang itu sendiri menyimpan filosofi yang sangat tinggi dan merupakan sarana nenek moyang dalam memperkuat persatuan dan kesatuan. Pentingnya ritual adat Mappadendang termasuk melaksanakan nilai-nilai sistem perekonomian Islam, yaitu menyuarakan kerja yang bersungguh sungguh dalam mencari rezeki yang halal, membentuk masyarakat dengan tatanan sosial yang solid, keadilan distribusi pendapatan termasuk menghapuskan monopoli, kebebasan individu dalam kesejahteraan sosial. (Abdul Rahim: 2016)

Awalnya Mappadendang berawal dari adat panen atau kebiasaan yang dilakukan para petani ketika sedang panen. Yaitu mulai dari turun ke sawah, membajak, sampai tiba waktunya panen raya. Ada upacara appalili sebelum pembajakan tanah. Ada appatinro pare atau appabenni ase sebelum bibit padi disemaikan. Ritual ini juga biasa dilakukan saat menyimpan bibit padi di possi balla, sebuah tempat khusus terletak di pusat rumah yang ditujukan untuk menjaga agar tak satu binatang pun lewat di atasnya.

Lalu ritual itu dirangkaikan dengan massureq, membaca meong palo karallae, salah satu epos Lagaligo tentang padi. Dan ketika panen tiba digelarlah katto bokko, ritual panen raya yang biasanya diiringi dengan kelong pare. Setelah melalui rangkaian ritual itu barulah dilaksanakan Mapadendang. Di Pinrang dan sekitarnya ritual ini dikenal dengan Mappadendang, yang berarti kegiatan menumbuk padi muda. Mappadendang atau apadekko konon 
memang berawal dari aktifitas ini.( Puspitasari Rakhmat, Jeanny Maria Fatimah: 2020)

Tradisi Mappadendang dalam meningkatkan hubungan sosial. Dapat dimaklumi bahwa, manusia adalah makhluk sosial, yang perlu berinteraksi dengan manusia lainnya. Ada beberapa tujuan hubungan sosial diantaranya adalah sebagai berikut:

1. Menjalin hubungan persahabatan; adalah sifat manusia merasa ingin menjalin persahabatan dengan sesama. Dengan menjalin persahabatan, manusia menganggap itu adalah salah satu dari solusi dalam meneruskan hidup, selain sebagai upaya saling berbagi dan saling membantu.

2. Menjalin hubungan usaha; tujuan ini erat kaitannya dengan keinginan manusia yang hendak mendapatkan taraf hidup yang layak di mata masyarakat. Dikatakan, manusia perlu bekerja untuk mendapatkan kesejahteraan dalam kehidupan. Menjalin hubungan usaha, seperti, melakukan hubungan dagang atau bisnis, manusia perlu banyak mengetahui bagaimana cara efektif berhubungan dengan masyarakat.

3. Mendiskusikan sebuah persoalan; musyawarah adalah salah satu hubungan sosial yang bisa sering kita lihat. Di setiap kelompok masyarakat, kita menemukan sekelompok orang melakukan rapat atau musyawarah untuk menyelesaikan permasalahan yang menimpa mereka. tak jarang, sebuah masalah hanya mengganggu satu individu, dimusyawarahkan dengan satu kelompok perumahan. Mengapa? Karena satu individu itu telah dianggap sebagai bagian dari kelompok masyarakat tersebut. Kalau saja, individu berniat tinggal sendiri, dan ia mendapatkan masalah sendiri, maka ia tentunya tidak akan mendapatkan orang banyak menyelesaikan masalah yang patutnya bisa diselesaikan oleh orang banyak.

4. Melakukan kerja sama; kerja sama, juga sebagai salah satu tujuan, dari hubungan masyarakat, dan kerja sama, adalah sebuah simbol ketidakmampuan seorang manusia dalam menyelesaikan masalah sendiri-sendiri (Hasdalia, Skripsi)

Nilai adalah sesuatu yang berharga, bermutu, menunjukkan kualitas dan berguna bagi manusia. Sesuatu itu bernilai berarti 
sesuatu itu berharga atau berguna bagi kehidupan manusia, nilainilai itu sangat banyak mempengaruhi tindakan dan perilaku manusia, baik secara individual, kelompok atau masyarakat secara keseluruhan tentang baik buruk, benar salah, patut atau tidak patut. Suatu nilai apabila sudah membudaya di dalam diri seseorang, maka nilai itu dijadikan sebagai pedoman atau petunjuk di dalam bertingkahlaku. Hal ini dapat dilihat dalam kehidupan sehari- hari, misalnya gotong royong, budaya malas dan lain-lain.

Nilai Islam yang termuat dalam tradisi mappadendang yaitu memperkuat hubungan silaturahmi antar sesama manusia, sebagaimana yang dianjurkan dalam agama untuk tetap menjaga hubungan silaturahmi. Sebagaimana ajaran Islam yang termaktub dalam Alquran diantaranya sebagai berikut: QS. Ali Imran /3:103 berbunyi: Terjemahnya: Dan berpeganglah kamu semuanya kepada tali (agama) Allah, dan janganlah kamu bercerai berai. (Wawan Saputra, Skripsi)

Pelaksanaan tradisi mappadendang terdiri dari dua tahap, yaitu tahap persiapan, tahap pelaksanaan. Tahap persiapan adalah tahap yang berguna untuk memutuskan dan mengumpulkan alat serta bahan yang akan digunakan dalam pelaksanaan tradisi mappadendang. "Alat yang paling penting itu adalah lesung sama alunya, jangan lupa juga sama pemukul atau passerenya." Ungkap salah seorang informan".

Setelah mempersiapkan perlengkapan maupun peralatannya maka masuklah pada tahap pelaksanaan mappadendang. Adapun acara yang dilaksanakan dalam tahap pelaksaaan adalah: Ma'baca Doang (baca doa) Mabaca Doang (baca doa ) merupakan proses berdoa bersama sebagai tanda rasa syukur dan doa keselamatan bagi keluarga yang sudah meninggal maupun yang masih hidup menurut kepercayaan masyarakat setempat.

Mappadendang atau yang lebih dikenal dengan sebutan pesta tani pada suku Bugis merupakan suatu pesta syukur atas keberhasilannya dalam menanam padi kepada Tuhan. Mappadendang sendiri merupakan suatu pesta yang diadaakan dalam rangka besar-besaran. Yakni acara penumbukan gabah pada lesung dengan tongkat besar (Alu) sebagai penumbuknya. 
Mappadendang adalah tradisi menumbuk padi karena dulu tidak pakai mesin giling makanya mappadendang. Pesta rakyat ini umumnya dilaksanakan oleh tujuh orang, yaitu terdiri dari empat orang perempuan yang berperan sebagai Indoq padendang dan 3 orang laki-laki, yang dua berperan sebagai passeppi' padendang (sayap di kepala lesung) dan satu lagi berperan sebagai Passere. Bunyi ketukan alu yang berulang-ulang dan berirama yang diciptakan oleh tujuh orang ini merupakan puncak dari tradisi mappadendang. Yang sangat berperan dalam mapppadendang ini adalah Passere.

Passere dituntut untuk dapat menciptakan suatu suasana yang meriah setelah panen tiba. Passere dalam hal ini akan menjadi suatu pusat perhatian yang akan menghibur semua penonton dengan segala kelucuan yang akan ditampilkan untuk menghibur penonton. Bunyi ketukan alu terus berlangsung sampai rangkaian acara tersebut selesai. (Nurfadilah, Skripsi)

Di zaman yang sudah sangat modern ini apakah eksistensi tradisi Mappadendang di bugis masih bertahan? Melihat anak muda zaman sekarang lebih tertarik kepada hal-hal yang berbau teknologi karena sudah terkena modernisasi ketimbang budaya tradisional mereka sendiri. Adakah cara yang bisa dilakukan agar tradisi seperti Mappadendang ini bisa menarik perhatian mereka? Tentu saja.

Melihat anak muda zaman sekarang lebih tertarik dengan teknologi, mengapa kita memanfaatkan teknologi itu saja untuk mengenalkan mereka dengan tradisi mappadendang. Caranya? Mudah saja kita tinggal mengupload video tentang mappadendang ke media sosial seperti facebook, tapi dikemas secara lebih menarik seperti mengeditnya dengan bagus walaupun sebenarnya acaranya jauh lebih menarik dilihat langsung ketimbang video. Hal-hal seperti inilah yang mampu menggugah minat anak muda karena terlihat lebih keren.

"Sebenarnya agar tradisi seperti ini tetap lestari ialah dengan cara mengenalkan pada anak sedari kecil agar di masa selanjutnya akan nada penerus dari mappadendang ini. Jadi mulai sekarang kita harus tahu tradisi sendiri agar kedepannya tradisi seperti ini tidak punah, bukankah suku bugis akan terlihat berbeda jika mempunyai bnyak tradisi yang masih berlangsung sampai sekarang seperti 
mappadendang dan kitapun akan merasa bangga dengan pencapaian itu." Jelas salah seorang informan".

Mappadendang adalah salah-satu tradisi suku bugis yang dimana bermakna rasa syukur kepada sang maha kuasa atas rezeki berlimpah yang telah diberikan kepada kita. Dan menuangkannya dengan menggelar acara pesta panen, menumbuk padi pada lesung. Kita harus senantiasa melestarikan tradisi yang sudah turun-temurun ini agar kelak keturunan kita bisa merasakan bagaimana meriahnya mappadendang, bukan hanya mendengar cerita dari orang tua mereka tanpa merasakan langsung. 


\section{Biodata Penulis}

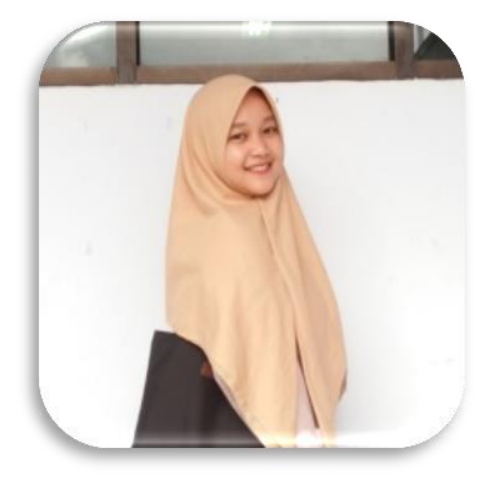

FITRIANA, Tempat tanggal Lahir, Lapalopo, 06 Januari 2000 Alamat Pinrang. Jenjang Pendidikan: SDN 190 Mattiro Bulu. SMPN 1 Mattiro Bulu. SMAN 7 Pinrang. Institut Agama Islam Negeri (IAIN) Parepare

\section{Motto}

"Segala sesuatu yang bisa kamu bayangkan adalah nyata" 


\section{Warisan Budaya Maccera Manurung Di Desa Kaluppini Kabupaten Enrekang}

Pergeseran nilai-nilai pancasila dikalangan remaja Indonesia diakibatkan oleh globalisasi. Dampaknya, masyarakat melupakan tradisi adat yang dulunya dipegang teguh dan dianggap sangat sakral pemahaman lisan maupun tulisan dan keragaman budaya seperti itu. Keragaman budaya sesunggunya terletak pada budayabudaya lokal, beberapa hal yang termasuk budaya lokal diantaranya adalah cerita rakyat, lagu daerah, ritual kedaerahan, adat istiadat daerah, dan segala sesuatu yang bersifat dalam pelaksanaannya, Salah satu tradisi upacara adat yang tergolong hampir hilang akibat pengaruh globalisasi yaitu tradisi upacara adat maccera manurung di Sulawesi Selatan.

Di daerah Massenrempulu salah satu desa yang melakukan tradisi upacara adat ini yaitu Desa Kaluppini. Kebudayaan ini sangat menarik dan unik karena pelaksanaannya hanya sekali dalam delapan tahun selama empat hari berturut-turut. Istilah maccera manurung mempunyai arti "Maccera" berasal dari bahasa Bugis yaitu "Cera" artinya meneteskan darah dan" To Manurung" artinya orang yang berasal dari suatu tempat yang tertinggi, beradaptasi dengan masyarakat setempat dengan membawa pesan-pesan dan ajaranajaran yang baik. Oleh sebab itu, upacara adat ini dipimpin oleh tetua adat setempat dan dilakukan dengan beberapa tahapan.

Salah satu tradisi upacara adat di Sulawesi-Selatan yang mulai pudar di kalangan masyarakat yaitu tradisi upacara adat maccera manurung pada masyarakat Massenrempulu Kabupaten Enrekang. Maccera manurung merupakan tradisi upacara adat kuno yang dilaksanakan satu kali selama delapan tahun dan upacara ini telah dilaksanakan beratus tahun yang lalu. Berdasarkan latar belakang di atas peneliti ingin mengetahui makna filosofi yang terkandung dalam serangkaian tradisi upacara adat maccera manurung serta proses pelaksanaannya.

(1) Proses upacara maccera manurung dilaksanakan selama empat hari yang dimulai pada hari jumat sampai dengan hari senin. 
Pelaksanaannya dimulai mappabangun tanah, macce'do mayang, ma' peong, ma'sodi gandang, Liang Wai, sipallolongana atau biasa na bilang orang disini Tuna' ada sola Matalunna.

(2) Makna filosofi yang terkandung dalam tradisi upacara adat Maccera Manurung dalam setiap tahapan pelaksanaanya. (a) Ma'pabangun tanah, masyarakat Massenrempulu meyakini tanah adalah inti dari seluruh jagad dan dimaksudkan sebagai doa dalam menghadapi delapan tahun yang akan datang. (b) liwang wai pengambilan air dewata dan penentu nasib (c) maccedo mayang sebagai keselamatan pelaksanaannya.

Proses awal adalah menabuh gendang semalam suntuk untuk membangkitkan tanah. Masyarakat percaya kalau tanah merupakan inti dari seluruh jagat. Sebagai tanda peresmian dimulainya acara maccera manurung, gendang dipukul satu kali. Ritual selanjutnya antara lain Liang Wae, Ma'peong, dan hajatan penyembelihan hewan yang dagingnya dimasak bersama-sama lalu dibagi-bagikan ke setiap masyarakat yang hadir untuk dimakan bersama-sama. Terkandung dalam serangkaian tradisi upacara adat maccera manurung. Ritual adat maccera manurung tradisi budaya kuno yang sejak lama dilakukan oleh masyarakat Kaluppini sampai saat ini.

Ketika musim telah tiba, masyarakat Desa Kaluppini, Kecamatan Maiwa, Kabupaten Enrekang mengadakan pesta adat yang dinamakan maccera manurung. Desa Kaluppini sendiri berjarak sekitar 9 kilometer dari ibu kota Enrekang, bisa menggunakan roda dua ataupun roda empat selama kurang lebih 30 menit. Menurut data, desa Kaluppini terdiri dari sekitar tiga ratus kepala keluarga dengan mata pencarian bertani, berkebun, berternak sapi dan ayam. Konon banyak pemuda pergi merantau antara lain Kalimantan, Malaysia dan ke Papua untuk mencari kehidupan lebih baik. Dalam kelembagaan adat desa Kaluppini mencakupi desa Lembang, Tokonang dan Rosoang. Desa Kaluppini perbatasan dengan Tokonang di utara Lembang di selatan Tobalu di bagian timur dan Ranga di bagian barat. Kronologi Pengewaran di Kaluppini diawali suatu masa bumi pertiwi Kaluppini pernah mencapai puncak kesejahteraan area persawahan yang menguning untuk dipanen dan ladang dipenuhi oleh tanaman yang menghasilkan buah dan 
tumbuhan yang berhasil. Maka kegembiraan penduduk senantiasa mewarnai desa Kaluppini. Tetapi norma adat telah terlupakan maka diturunkanlah azab ditanah kaluppini hingga kehidupan waktu itu hampir punah maka hidup terlepas dari bencana.

Kesembilan bersaudara berkumpul di Wikka wala-wala dusun Palli. Merekapun sepakat mengadakan ritual untuk permohonan ampun kepada Tuhan atas kesalahan dan keterpurukan. Ritual dinamakan pengewaran dan permohonan meraka diijabah keadaan kembali seperti sedia kala maka keenam orang yaitu saudara yang bermukim di luar Kaluppini segera kembali di daerahnya, sebelum berpisah merekapun membuat perjanjian disaat Orro dan Bobo tanda dilangit atau tanda tepat berada di tengah langit nama cora ido bulan atau saat bulan purnama taong alippu yakni peredaran tahun berdasarkan tahun alih delapan tahun hari jum'at (allo ju'ma) keempat tanda itulah yang dijadikan patokan oleh mereka kumpul kembali.

Menyambut ritual adat desa Kaluppini merekapun bergotong royong membuat jalan untuk ketertiban bersama. Merekapun membuat pelataran masjid semacam ruang khusus yang di pagari pohon bambu tempat itu nantinya, area penempatan gendang atau beduk ketika diarak keluar dari dalam masjid dan disinilah gendang tersebut akan di cera atau ditetesi darah ayam sebelum pemanggilan sembilan bersaudara dimulai. Sedangkan terkhusus enam bersaudara yang meninggalkan desa Kaluppini maka dibuatkan tempat khusus titik-titik tertentu di area pelataran masjid. Tampak pula yang perantau ikut datang untuk menyaksikan acara ritual adat ini, mereka rata-rata dari Kalimantan, Malaysia dan Papua. Para perantau itu mengharapkan semacam berkah atau doa keselamatan mereka untuk kembali merantau nantinya, adapun datang untuk silatuhrahmi setelah lama tidak bertemu.

Adapun nama mapadendang yaitu nama tradisional yang dilakukan setiap adat pangewaran Kaluppini, kegiatan ini dilakukan untuk rasa syukur dengan hasil panen yang berlimpah. Kemudian dilanjutkan ritual majjaga bulan yang dilakukan tiga bulan sebelum masa pelaksanaan sebagai mana tiga cakupan besar yaitu lolo tallu, lolona lato tau, lolona lato dalle dan lolona tobarang ngapa masingmasing ke empat tersebut majjaga bulan. Menurut salah satu orang 
Kaluppini yaitu bernama Rahman, pelaksanaan maccera manurung sudah dilakukan sejak ratusan tahun lalu yang disalurkan oleh para leluhur secara turun temurun hingga saat ini.

Ritual adat maccera manurung adalah tradisi budaya kuno yang ada di Desa Kaluppini, Kabupaten Enrekang. "Maccera" (mendarah) atau bisa diartikan menyembelih binatang untuk dipersembahkan bagi penguasa alam semesta. "Manurung" yang berarti cahaya yang turun dari langit. Tiga sifat-sifat khusus dalam arti tumanurung yaitu: Pertama, tumanurung yang dimaksud adalah dia sudah tidak ada/menghilang, yang tertinggal hanya pakaian dan krisnya. Kedua, tumurung yaitu kita bisa merasakan di dekat kita tetapi tidak bisa dilihat dengan mata kepala sendiri. Ketiga, tumurung hanya datang ketika ritualnya telah dilakukan.

Sedangkan 'Manurung' dalam terjemahan bebasnya berarti sesuatu yang turun dari kayangan atau suatu yang diturunkan langsung dari Tuhan. Meskipun pemahaman Islam telah menjadi bagian utama masyarakat Enrekang, namun estetika dari tradisi maccera tetap dilaksanakan atas dasar penghargaan dan penghormatan terhadap leluhur. dengan cara melakukan upacara adat yang dilaksanakan oleh masyarakat di desa Kaluppini.

Adapun gandrang yang diambil lalu dilakukan dengan pemukulan gandrang, gandrang dipukul sampai tujuh kali sebagai tanda berkah, bagi yang mendapatkan pengunci gandrang (paso). "Maccera Manurung" atau biasa disebut penyembelihan hewan yang ternak untuk dipersembahkan kepada to manurung (raja atau pemimpin). Kegiatan ini berlangsung hanya delapan tahun satu kali pada september atau oktober, setelah panen berhasil merekapun memotong ratusan ekor ayam, sapi dan kerbau mengungkapkan rasa syukur atas keberhasilannya.

Ritual yang dilakukan dalam rangka kegiatan acara yang di laksanakan di desa Kaluppini yaitu mapanongo gandrang yang artinya turun gendang. Gendang akan diambil lalu dikeluarkan dari masjid, adapun juga pemotongan hewan sebagai tanda peresmian dimulainya acara adat maccera manurung. Dan kita harus mempertahankan budaya ini dengan cara melakukan kegiatan yang telah di tentukan agar budaya kita tetap terjaga dengan baik. 
Tradisi upacara adat maccera manurung dilaksanakan hanya delapan tahun satu kali, sebagai tanda syukur keberhasilan bagi penduduk desa Kaluppini, dan di gelar kurang lebih empat hari lamanya. Upacara adat ini mengandung makna religius serba sakral dan terpisah dari hal yang bersifat duniawi dilakukan dengan cara turun-temurun yang dipercaya oleh masyarakat setempat. 


\section{Biodata Penulis}

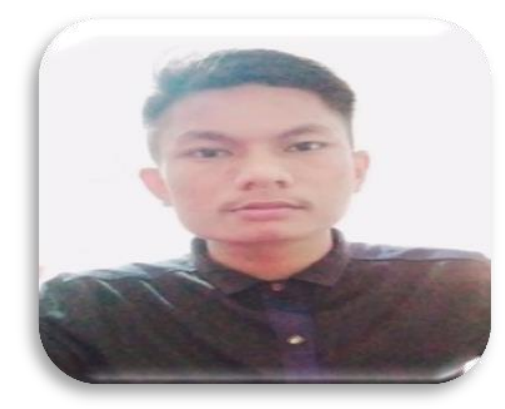

Muhammad Faizul Asri lahir di Pinrang, Sulawesi Selatan, Pada tanggal 05, Februari, 2000. Ia adalah mahasiswa dari Institut Agama Islam Negeri (IAIN) Parepare, dengan program studi (prodi) Jurnalistik Islam. Lahir dari orang tua bernama Abbas (ayah) dan Fatimah (ibu), sebagai anak ke-3 dari empat bersaudara. Riwayat pendidikan di kota asal yaitu dimulai dari SDN 257 Pinrang, SMPN 2 Patampanua, SMAN 5 Pinrang, hinggah akhirnya bisa menempuh masa kuliah di Fakultas Ushuluddin, Adab dan Dakwah IAIN Parepare, Sulawesi Selatan pada tahun 2018.

"Motto"

"Usaha terus meski situasi semakin sulit" 


\section{Budaya Mahpalili}

Acara adat sebagai suatu kekayaan budaya dan tradisi tetap dipertahankan di sulawesi-selatan untuk mengawali musim. Acara adat mahpalili. Upacara adat yang dilakukan secara turun-temurun diyakini masyarakat setempat sebagai pedoman bagi petani untuk memulai musim tanam padi.

Suku bugis adalah suku yang lebih dominan di pulau Sulawesi ini. Suku bugis mayoritas adalah pedagang jadi tidak heran jika ratarata pasar di pulau ini dikuasai oleh suku bugis. Suku bugis adalah suku yang taat beragama, menjunjung tinggi harga diri dan martabat. Suku ini sangat menghindari tindakan-tindakan yang mengakibatkan turunnya harga diri atau martabat seseorang.

Dalam masyarakat bugis, terdapat beragam tradisi yang dianut dan masih dilaksanakan sampai sekarang. Salah satunya adalah Mahpalili. Salah satu yang menarik dari mahpalili yaitu mereka melakukan mabaca-baca, menari. Dianggap sebagai bentuk komunikasi agar diberikan rahmat atau dberikan perlindungan dari ha-hal yang dapat menurunkan hasil panen petani. Hal ini lah yang menarik menjadikan ritual Mahpalili sebagai ritiual yang sangat unik dikalangan masyarakat bugis.

Mahppalili berasal dari kata mahppalili (Bugis) Appalili (Makassar) berasal dari kata palili yang mengandung arti yang sama yakni menjauhkan hal-hal yang akan menggangu atau merusak tanaman padi. Mahpalili atau appalili adalah ritual turun-temurun yang dipegang oleh masyarakat sulawesi-selatan. Diketahui bahwa ritual Mahppalili telah dilakukan oleh nenek kita. Hingga hari ini, tradisi Mahppalili masih eksis dan praktiknya dapat ditemukan dibeberapan kabupaten di Sulawesi-selatan ini. Mahpalili adalah tanda untuk mulai menanam padi.

Tradisi ini masih berlangsung hingga saat ini yaitu dilaksanakan setiap panen dalam dua kali dalam setahun. Yang terlibat dalam acara ini Toko adat yang dikenal sebagai penghulu kampung. Pemerintahan kecamatan, kepolisian, toko tani, pejabat desa serta anggota kelompok tani. 
Menurut salah satu kelompok tani di desa salubon tersebut tujuan tradisi mahpalili ini adalah sebagai peralatan atau alat pemersatu dan sumber kerja sama maka dapat meningkatkan produksi dalam rangka meningkatkan kesejahteraan masyarakat.

Desa salubone ini lah merupakan tempat dimana masyarakat melakukan ritual mahpalili. Sebelum mereka turun ke sawah masyarakat berkumpul disuatu tempat di area persawahan atau biasa disebut Sanggar tani untuk memulai membajak sawah. Nah sebelum meraka melakukan ritual mahpalili itu masyarakat menghadirkan sejumlah makanan khas masyarakat bugis dan doa bersama.

Ritual mahpalili ini adalah tradisi yang patut dilestarikan karena budaya ini sejak dulu memang sudah dilakukan oleh nenek kita. Sebagai upaya melestarikan adat istiadat yang ada di desa salubone ini. Ritual sebuah teknik dalam membuat suatu adat, menciptakan dan memelihara mitos, juga adat dan agama. Ritual bisa pribadi maupun kelompok, wujudnya bisa berupa doa (mabacabaca) dan kata-kata seperti aamiin dan sebagainnya. Setiap ritual mempunyai makna yang dalam bagi budaya baik itu ritual kelahiran maupun kematian. Ritual tidak bisa dipisahkan dengan waktu pelaksaannya, ritual dilaksanakan pada waktu yang dianggap baik, waktu yang dipilih mempunyai makna tersendiri.

Ritual Mahpalili dilakukan setiap tahun, tepatnya dua kali dalam setahun, jadwal dilakukannya ritual mahpalili ini tidak menentu karena permasalahan air yang belum masuk dan sebagainya.

Menurut salah satu warga di desa salubone bahwasannya warga berharap debit air disaluran ke pekkabata ditambah untuk mencukupi kebutuhan areal persawahan petani, saat ini air yang dibutuhkan petani sangat besar jadi wajar jika debit air ditambah.

Untuk menjelaskan tradisi ini penulis menggunakan teori ritus yang dikemukan oleh Robertson Smits teori ritus adalah teori yang menganalisi satuan sistem kehidupan dari manusia seperti, sistem kepercayaan, ritual dan agama. Teori ini mengemukan tiga gagasan mengenai asas-asas dari kepercayaan dan agama pada umumnya. Gagasan yang pertama mengenai soal bahwa disamping sistem 
keyakinan dan doktrin, sistem upacara juga merupakan suatu perwujudan dari religi atau agama yang memerlukan studi dan analisis yang khusus.

Hal yang menarik Robertson Smits adalah bahwa dalam banyak agama upacaranya itu tetap, walaupun latar belakang, keyakinan, maksud atau doktrinnya berubah. Gagasan yang kedua adalah bahwa upacara religi atau agama yang biasanya dilaksanakan oleh banyak warga masyarakat pemeluk religi atau agama yang bersangkutan bersama-sama mempunyai fungsi sosial untuk mengintensifikasi solidaritas masyarakat. (www.google.com)

Artinya disamping sebagai kegiatan keagamaan tidak sedikit dari masyarakat yang melaksanakan upacara religi atau agama menganggap melakukan upacara itu sebagai suatu kewajiban sosial yang harus dipenuhi kelompok yang menyakini tersebut.

Gagasan yang ketiga adalah teorinya mengenai fungsi upacara bersanji. Dikatakan bahwa upacara seperti itu, dimana manusia menyajikan seekor binatang terutama darahnya kepada dewa, kemudian memakan sendiri sisa daging dan darahnya maka itu termasuk cara dalam ritual mereka. Oleh Robertson Smith juga dianggap sebagai suatu aktivitas atau mendorong rasa solidaritas dengan dewa atau para dewa. Dalam hal itu atau para dewa dipandang juga sebagai warga komunitas walau sebagai warga istimewah.

Teori ritus mengungkapkan ritual atau upacara sesajian yang diselenggarakan oleh kelompok masyarakat tertentu merupakan berwujudan dari "simbol" dari masyarakat tersebut yang dianggap sangat penting. Terkait dengan sentuhan rohani, menurut teori ritus, manusia dalam hal memenuhi segala keinginnya senantiasa menggunakana alam sebagai media pencapainya. Adanya anggapan mengenai alam selain sebagai sumber kehidupan yang mampu mempengaruhi dan menciptakan proses-proses yang berlangsung alam raya. Guna memenuhi berbagai maksud tertentu manusia memepergunakan teknik-teknik atau cara-cara serta segenap pengetahuan yang mempergunakan alam sebagai media untuk mencapainya.

Menurut salah satu tokoh masyarakat Puimam Daud mahpalili merupakan tradisi yang patut dilestarikan. Budaya ini sejak dulu 
memang sudah dilakukan nenek moyang kita, jadi saya berharap tradisi ini terus dilakukan karena ini sebagai upaya melestarikan adat istiadat yang ada di desa salubone ini

Prosesi ritual dilakukan dengan sangat hikmat. Prosesi ritual mahpalili tersebut dimulai dengan prosesi tudang sipulung atau musyawarah di area persawahan atau biasa disebut sanggar tani untuk memulai musim tanan padi. Semua proses memiliki fungsi dan makna yang berbeda, semua prosesi ritual mahpalili diyakini mampu mendatangkan keberkahan dan menjaga tanaman padi dari hal-hal yang dapat menurun kan padi.

Makna ritual mahpalili merupakan bentuk penghormatan dan rasa syukur kepada yang telah memberikan keberkahan selama ini. Ritual mahpalili berfungsi menjaga tanaman padi dari hama atau hal yang dapat merusak tanaman padi. Sehingga menurunkan hasil panen.

Tujuannya mahpalili ini adalah sebagai peralatan atau alat pemersatu dan sumber kerja sama maka dapat meningkatkan kesejahteraan masyarakat. 
Biodata Penulis

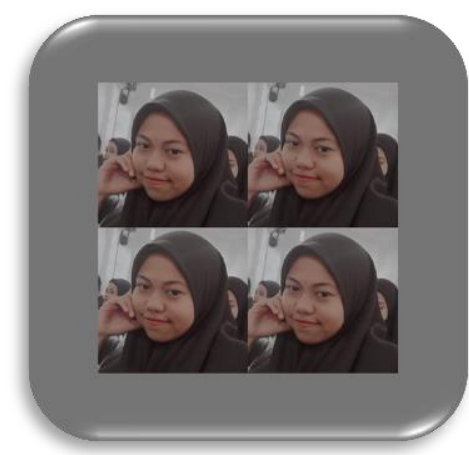

Sharifa Mahasiswi IAIN Parepare Prodi Jurnalistik Islam Tempat/Tgl: Malaisya,17-11-2000. Alamat, Salubone, Kecamatan Duampanua Riwayat Pendidikan SDN 134 Data SMP 05 Data. SMK 05 Bittoeng 


\section{Ciri Khas Baju Bodo (Tokko) Adat Bugis Yang Terletak Di Sulawesi Selatan Indonesia}

Tiap-tiap provinsi tentulah memiliki pakaian khas masingmasing, bahkan ada yang satu provinsi yang memiliki dua, tiga bahkan lebih dari itu. Dan ini adalah kekayaan budaya kita sesungguhnya, untuk itu mari kita jaga dan lestarikan budaya asli Indonesia. Sudah saatnya bangsa ini menyadari akan kekayaan dan keragaman budaya bangsa ini menjadi aset dan kebanggaan yang bernilai di mata dunia. Pakaian adat merupakan suatu simbol identitas kebudayaan dari suatu daerah tertentu yang sudah ada dari peninggalan nenek moyang dan merupakan warisan budaya yang kekal selama masih ada yang melestarikannya.

Pakaian adat tradisional Indonesia merupakan salah satu kekayaan budaya yang dimiliki oleh negara Indonesia dan banyak dipuji oleh negara-negara lain. Dengan banyaknya suku-suku dan provinsi yang ada di wilayah negara Indonesia, maka otomatis pula banyak sekali macam-macam baju adat yang dipakai oleh masingmasing suku di seluruh provinsi Indonesia. Karena dari banyaknya suku-suku yang ada di Indonesia memiliki ciri-ciri khusus dalam pembuatan ataupun dalam mengenakan pakaian adat tersebut.

Pakaian khas tersebut selain indah juga mempunyai arti tertentu. Untuk saat ini pakaian adat banyak yang tidak dipergunakan dalam kehidupan sehari-hari. Biasanya pakaian adat digunakan saat upacara adat, upacara perkawinan dan saat memperagakan tarian atau pertunjukan daerah. Salah satu pakaian adat yang akan diangkat oleh penulis adalah baju tradisional Sulawesi-Selatan dari suku Makassar, suku Bugis dan suku Toraja dari tiga suku ini memiliki keragaman baju adat yang menjadi ciri khas dan ikon baju adat Sulawesi-Selatan.

Baju Bodo merupakan baju tradisional Bugis Makassar Baju Bodo (baju pendek) adalah penamaan Makassar sedangkan dalam bahasa Bugis disebut waju ponco tetapi nama baju bodo lebih terkenal dari pada waju ponco'. Bentuk baju bodo sampai saat ini 
tidak berubah. Bentuknya yang persegi empat dan pada kedua sisi bagian atas yang panjangnya kira-kira sejengkal tidak dijahit dengan tujuan untuk memasukkan tangan. Pada bagian depan dilubangi agar kepala dapat dimasukkan ke dalamnya dan sekaligus merupakan leher baju bodo.

Busana tradisional banyak macamnya, tiap-tiap daerah mempunyai busana tradisional sendiri-sendiri. Model, motif (ragam hias), warna, tata cara pemakaian, dan lain-lain. Untuk pasangan yang cocok untuk baju bodo adalah jas tutup yang dipakai oleh pria, memakai pakaian adat Bugis lengkap, salah satunya adalah jas tutup. Jas tutup adalah pakaian kehormatan Bugis sehingga pada saat prosesi adat ataupun acara-acara adat menggunakan pakaian lengkap. Menurut narasumber baju adat Bugis semakin gelap warna jas tutupnya semakin tinggi kebangsawanannya, dengan menggunakan simbol warna kita dapat mengetahui derajat bangsawan panglima dan pembantu.

Baju tokko ini terbuat dari serat-serat nenas yang ditenun secara tradisional. Hasil tenunan itu merupakan kain yang berbentuk segi empat. Untuk membuat baju tokko ini maka kain yang bersegi empat untuk membuat baju tokko ini maka kain yang bersegi empat panjang itu dilipat dua kemudian kedua sisinya dijahit, untuk lubang lengannya disisakan kira-kira sejengkal pada bagian depannya dibuat lubang leher yang berbentuk lonjong kemudian pinggirnya dijahit secara halus.

Modifikasi baju bodo suku kajang dari kain organza dengan tope le'leng mempunyai dua bagian yaitu bagian atas atau blus yang berbentuk siluet $\mathrm{H}$ dan bagian bawah yaitu rok dengan menggunakan warna hitam sebagai symbol masyarakat suku kajang dengan menggunakan kain organza, model baju yang telah di modifikasi berbentuk persegi empat degan leher $v$ dengan tambahan brokat, payet bambu, payet butir-butir, dan payet piringan,

Proses pembuatan modifikasi baju bodo suku kajang dari kain organza dengan tope leleng Proses pembuatan modifikasi baju bodo yaitu terlebih dahulu mendesain ukuran kemudian membuat pola dasar lalu merubah pola setelah itu mengguting pola kemudian meletakkan pola di atas kain organza dengan tope le'leng lalu menggunting bahan yang telah diletakkan pola diatasnya setelah 
proses menggunting selesai, kemudian menjahit sisi baju lalu menyambung lengan dengan manset baju setelah itu dibagian leher di klim setelah semua terjahit pada bagian leher diberikan lekapan dan garniture payet piringan dan payet bambu begitupun dengan hiasan lengan manset yang diberi payet bambu dengan peletakkan garis secara vertikal. Kemudian pada bagian rok dipasangkan res pada bagian belakang kemudian dijahit masing-masing sisi, setelah semua sisi dan res selesai kemudian pemasangan ban pinggang lalu di beri kancing kait rok, dan pada bagian bawah rok di klim lalu motif kain di beri hiasan payet bambu.

Makna warna baju tokko yaitu: Warna jingga, dipakai oleh perempuan umur 10 tahun. Warna jingga dan merah digunakan oleh perempuan umur 10-14 tahun. Warna merah untuk 17-25 tahun. Warna putih digunakan oleh para inang dan dukun. Warna hijau diperuntukkan bagi puteri bangsawan. Warna ungu dipakai oleh para janda.

Namun, Baju Bodo yang dikenal sebagai pakaian yang sering digunakan pada acara pengantin dan acara-acara adat saat ini mulai terkikis oleh kemajuan zaman. Baju bodo kini seolah terpinggirkan, digantikan oleh kebaya modern, gaun malam yang katanya modis, atau busana-busana yang lebih simpel dan mengikuti trend.

Baju yang digunakan dalam tradisi ini menurut salah seorang warga mengatakan bahwa baju yang digunakan adalah Baju bodo "Adat suku Bugis dan diperkirakan sebagai salah satu busana tertua di dunia. Perkiraan itu didukung oleh sejarah kain Muslim yang menjadi bahan dasar baju bodo". Jas tutup adalah Jas yang sering digunakan saat ada acara-acara pernikahan, acara adat, acara para pejabat di lingkungan provinsi Sulawesi-selatan." Baju seppa tallung Pada acara tersebut, busana Seppa Tallung yang diperlihatkan merupakan hasil dari modifikasi. Busana adat dari Sulawesi-Selatan ini ditambah dengan aksesoris yang semakin menakjubkan, yaitu sayap dan tanduk. Baju pattuqduq towaine. Busana adat Baju adat Sulawesi Selatan kali ini adalah Pattuqduq Towaine merupakan baju adat suku Mandar. Pattuqdu Towaine mencerminkan busana yang dipakai oleh perempuan mandar pada umumnya. 
cara mempertahankan pakaian adat Sulawesi Selatan, baju (bodo/tokko)?

a. Melakukan Event-event dengan memperkenalkan pakaian adat

b. Menjadikan pakaian adat sebagai resmi pada hari-hari tertentu

c. Memperkenalkan pakaian adat kepada turis-turis mancanegara maupun lokal

d. Pemerintah maupun lembaga terkait dapat melakukan event perlombaan kepada kaum muda untuk memodifikasi pakaian adat sesuai dengan perkembangan zaman.

e. Melakukan pameran-pameran pakaian adat.

f. Memakai pakaian adat pada acara-acara pawai dan sebagainya.

Baju tokko ini terbuat dari serat-serat nenas yang ditenun secara tradisional. Hasil tenunan itu merupakan kain yang berbentuk segi empat. Untuk membuat baju tokko ini maka kain yang besrsegi empat untuk membuat baju tokko ini maka kain yang bersegi empat panjang itu dilipat dua kemudian kedua sisinya dijahit, untuk lubang lengannya disisakan kira-kira sejengkal pada bagian depannya dibuat lubang leher yang berbentuk lonjong kemudian pinggirnya dijahit secara halus. 
Mahasiswa Jurnalistik Islam

\section{Biodata Penulis}

Nurul Khadijah, Parepare, 03 Desember 1999 


\section{Makna Musik Bambu (Bas) Pada Masyarakat Desa Tongko Enrekang}

Indonesia merupakan Negara yang kaya keanekaragaman budaya salah satunya alat musik tradisional. Alat musik tradisional adalah alat musik yang berkembang dari generasi ke generasi berikutnya pada suatu daerah yang digunakan untuk mengiringi lagu-lagu daerah dan sebagai sarana hiburan bagi masyarakat.

Kebudayaan Enrekang (Massenrempulu) berada diantara kebudayaan Bugis, Mandar dan Tana Toraja. selain masih melestarikan kehidupan adat istiadat, masih melaksanakan upacara tradisional seperti pesta panen, perkawinan, sunatan, dan upacara adat lainnya yang mementaskan musik bambu (bas).

Musik bambu (bas) adalah sebuah kelompok musik bambu yang terdiri dari banyak pemain, meliputi perempuan dan laki-laki. Dalam permainan musik bambu mempunyai seorang dirgen untuk mengatur agar music selaras dan harmoni. Instrument suling yang kecil biasanya dimainkan oleh kaum wanita sedangkan kaum laki-laki memainkan instrument yang besar. Musik bambu ini kebanyakan dipentaskan pada kegiatan upacara-upacara adat seperti pesta perkawinan, sunatan, syukuran dan pesta-pesta adat lainnya. Musik tradisional ini muncul dan berkembang pada zaman kerajaan massenrengpulu yang berada di kekuasaan Raja Matindo Duri dimana pada zaman ini masyarakat di tanah Duri sudah mempunyai berbagai jenis alat musik tradisional seperti Bagao, Capunde, Bara Baru'tun dan Gendang Kabo'bonga. (Hasman: 2011)

Modernisasi saat ini menjadi ancaman punahnya musik bambu tersebut. Sedikit sekali generasi muda yang berminat untuk mempelajarinya sebagai musik warisan leluhur yang harus dipertahankan. Ditambah lagi kurangnya wadah untuh mempertahakan kebudayaan musik bas tersebut.

Kebanyakan Pemain Musik Bas itu terdiri dari orang tua yang sudah memiliki keluarga dan mempunyai kesibukan tersendiri, sehingga untuk melakukan pembinaan kepada generasi selanjutnya terkendala akan kesibukan sehari para pemain musik Bas. Ini 
menjadi PR penting bagi pemerintah daerah mengembangkan kebudayaan hasil dari orang-orang terdahulu kita agar generasi berikutnya bisa ikut merasakan kebudayaan nenek moyang kita khususnya masyarakat Enrekang.

Budaya adalah bentuk jamak dari kata "Budi" dan "Daya" yang berarti cinta, karsa dan rasa. Kata budaya sebenarnya berasal dari bahasa Sansakerta, Budhayah yaitu bentuk jamak kata buddhi yang berarti budi atau akal. Kemudian pengertian ini berkembang dalam arti culture, yaitu sebagai segala daya dan aktivitas manusia untuk mengolah dan mengubah alam. (Elly M. Setiadi.dkk)

Istilah budaya bukan hanya merujuk pada sastra dan seni, tetapi juga pada keseluruhan cara hidup yang dipraktikkan manusia dalam kehidupan sehari-hari yang ditransmisikan dari satu generasi ke generasi berikutnya (I Gede Pintana) Dengan kata lain budaya selalu diturunkan secara turun-temurun oleh generasi berikutnya bukan dari segi sastra, seni dan bahkan bentuk pola hidup masyarakat yang menjadi ciri khas sebuah daerah. Salah satu bentuk kebudayaan adalah alat musik tradisional yang merupakan sarana pengiring lagu-lagu tradisonal.

Seni Musik, dilansir dari Ensiklopdi Nasional Indonesia (1990: 413) disebutkan bahwa kata musik berasal dari bahasa Yunani Mousike yang diambil dari nama dewa mitologi Yunani yaitu Muosa yakni yang memimpin dan ilmu. Sedangkan Tradisional berasal dari dari bahasa latin yaitu Traditio yang artinya kebiasaan masyarakat yang sifatnya turun-temurun. Jadi dapat di simpulkan bahwa Seni musik Tradisional adalah sebuah seni musik yang menggambarkan ciri khas dari kalangan masyarakat tertentu secara turun temurun (https://ilmuseni.com) Musik di era sekarang banyak mengalami pergeseran yang dulu lebih mengarah pada kultur budaya yang ada di daerah sekarang mulai mengalami pergeseran dikarenakan masuk budaya-budaya asing yang berkembang pesat khususnya di bagian seni musik.

Perubahan seni musik yang ada pada era sekarang tak luput dari perkembangan teknologi yang menyebabkan masyarakat mudah menyerap budaya-budaya dari luar. Ini menjadi tantangan di era sekarang karena minimnya generasi-generasi muda yang ingin 
belajar dan mempertahankan budaya leluhur yang telah di turun secara turun temurun. Salah satu alat musik tradisional yang hampir punah keberadaannya ada alat musik bambu bas yang berasal dari daerah kabupaten enrekang.

Alat Musik Bas Enrekang. Keberagaman yang ada di Nusantara ini merupakan nilai lebih yang dimiliki oleh Negara salah satunya iyalah keberagaman dari alat musik tradisional. Alat musik tradisonal di Indonesia memiliki bentuk dan keunikan tersendiri, salah satunya iyalah alat musik bambu. Alat musik bambu ini memiliki ragam bentuk dan fungsi kegunaan, ada yang ditiup, digoyang-goyangkan dan ada pula ketuk.

Salah alat musik tradisonal yang ada pada daerah kabupaten enrekang yaitu alat bambu Bas. Selatan. Alat bambu Bas merupakan alat musik yang berasal dari bumi massenrempulu Enrekang yang menjadi sarana hiburan. Enrekang merupakan salah satu daerah yang ada di provinsi Sulawesi-selatan. Alat musik bambu Bas ini terbuat dari bahan dasar bambu dan cara penggunaan alat bambu tersebut yaitu dengan cara di tiup. Musik bambu (bas) adalah sebuah kelompok musik bambu yang terdiri dari banyak pemain, meliputi perempuan dan laki-laki. Dalam permainan musik bambu bas mempunyai seorang dirgen untk mengatur agar musik selaras dan harmoni. Instrument suling yang kecil biasanya dimainkan oleh kaum wanita sedangkan kaum laki-laki memainkan instrument yang besar. Musik bambu ini dahulunya kebanyakan dipentaskan pada kegiatan upacara-upacara adat seperti pesta perkawinan, sunatan, syukuran dan pesta-pesta adat lainnya (Hasman 2001)

Dengan perubahan zaman, alat musik Bas mulai terusik keberadaannya, di karenakan kurangnya minat generasi muda untuk melestarikan hasil kebudayaan dari orang terdahulu kita. Sangat di sayangkan kalau ini sampai punah, karena musik bambu Bas ini sudah menjadi ciri dari kebudayaan masyarakat enrekang. Peran pemerintah sangat diharapkan dapat menjaga dan melestarikan kebudayaan ini agar anak cucu kedapannya masih bisa melihat alat musik bambu Bas.

Teori Malinowski ini sangat nampak dalam pergeseran nilai nilai budaya kita yang cenderung ke barat yang identik dengan modernisasi. Teori singkronisasi dan tanggapan, (hamelink, 1983) 
menyatakan "lalu lintas produk budaya masih berjalan satu arah dan pada dasarnya mempunyai model yang sinkronik".

Teori orientation value of culture, menurut kluckhon dan strodberck tinggi nilainya dalam kehidupan manusia dan yang ada dalam tiap kebudayaan di dunia ini menyangkut paling sedikit lima hal, yakni: 1, Human nature 2. Man nature 3. Persoalan waktu 4. persoalan aktivitas 5 . Persoalan relasi.

Teori yang digunakan pada riset ini adalah teori sinkronisasi budaya. (http://mustazab81.blogspot) Musik Bambu Bas merupakan kebudayaan khas daerah kabupaten Enrekang yang kini terancam keberadaannya. Meski kini musik bas tersebut sudah jarang dipentaskan, tetapi masih ada beberapa masyarakat khususnya orang tua masih memainkannya sebagai sarana penghibur.

Adapun pernyataan dari informan yang menyatakan: "jarang mora tau ma bas te undi, to matua nasang ra to maningo na tangpakulle mo pang barab to ra na yara patuao ki to mang baraba" "sekarang ini sudah jarang sekali alat musik bas di mainkan di karenakan para pemain musik bas kebanyakan pemainnya terdiri dari orang tua dan lanjut usia dan mempunyai kesibukan lain seperti berkebun. Karena mata pencaharian utama mereka berkebun."

Berdasarkan hasil wawancara di atas dapat di jelaskan bahwa kebanyakan pemain musik Bas terdiri dari orang tua dan lanjut usia yang mempunyai kesibukan tersendiri yaitu mencari nafkah bagi keluarga seperti berkebun. Generasi muda yang sekarang ini yang di harapkan menjadi pelanjut tongkat estafet hidupnya kebudayaan musik bas kini jadi hayalan. Menurut informan mengatakan bahwa: " yatemai pea inde kampong susi kua eda na madoang pelaja ii mang bas nakabiran to musik-musik modern mo. Buda to pea yanna tamma mo massikola tassu enrekang mi dento me tiro jamn denton to massikola pole" " anak-anak sekarang banyak yang tidak peduli akan musik bas dikarenakan lebih tertarik pada budaya-budaya modern. Dan kebanyakan anak-anak di kampung kalau sudah tamat SMA kebanyakan mereka keluar untuk cari kerja dan kebanyakan juga melanjtkan pendidikan di luar Enrekang"

Berdasarkan hasil wawancara di atas dapat di jelaskan bahwa kebanyakan anak-anak di desa tongko banyak yang kurang peduli 
pada kesenian alat musik bambu bas di karekan lebih tertarik pada budaya-budaya luar dan kebanyakan anak-anak sekarang setelah tamat sekolah di jenjang SMA kebanyakan memilih kerja di luar dan adapun juga melanjutkan pendidikannya di luar kabupaten Enrekang. Bukan hanya kurangnya generasi muda yang mau melanjutkan tradisi kesenian musik bamboo bas tetapi kurangnya pementasan sekarang sehingga semakin terpinggirnya kebudayaan musik bambu bas dengan kebudayaan-kebudayaan moderen.

Saalah seorang informan mengatakan bahwa: "yatojolo mang Bas jora acara-acara tonggo susinna tujuh belasan. Pa ya to oo jarang mora den pi patambai mang bas na mane bang bas to tau apa na modern nasang mo to 0 " "dahulunya musik bambu bas banyak dipentaskan di acara besar seperti adat, nikahan, sunatan, dan acara- acara peringatan yang sifatnya sekala nasional seperti HUT Indonesia atau pawai. Sekarang sudah jarang sekali ada panggilan untuk pentas musik bas dikarenakan masyarakat sudah mulai memulai kebudayaan yang sifatnya modern"

Berdasarkan hasil wawancara diatas dapat di jelaskan bahwa dahulu musik bambu banyak dipentaskan di berbagai acara-acara seperti adat, nikahan, sunatan dan diacara peringatan seperti HUT Indonesia atau pawai. Seiring perkembangan zaman pementasan musik Bambu Bas sangat kurang dikarenakan tergeser budayabudaya yang sifatnya modern.

Seharusnya Pemerintah daerah melakukan tindakan cepat menanggapi ini karena ancaman keberadaan kebudayaan musik bas dapat dikatakan hampir punah dan Sangat di sayangkan ketika kebudayaaan musik bas ini harus punah, Menurut informan mengatakan Bahwa: "Yatemai pemerintah hrusra na tangani umbo na kua carana anggi na ta'de to budaya mang bas. Ke bisa i di kabuarang nenan nanei to pea undi to o melaja musik bas" Seharusnya pemerintah mengambil langkah cepat persoalan tindakan-tindakan yang dapat mencegah punahnya kebudayaan alat musik Bas ini. Kalau bisa pemerintah buat wadah kepada generasi muda untuk bisa berlatih kesenian musik bass seperti sanggar sehingga dapat mencegah punahnya kesenian tersebut"

Berdasarkan hasil wawancara di atas dapat di jelaskan bahwa peranan pemerintah sangat dibutuhkan dalam kondisi sekarang ini 
perihal ancaman punah kebudayaan musik bas. Pemerintah harus mengambil langkah cepat dikarenakan pementasan musik bas dapat dikatakan jarang ditemui. Dan wadah untuk berkembagnya kebudayaan musik bas sangat dibutuhkan sekarang ini melihat minim tempat pelatihan dan pembelajaran bagi masyarakat yang mau meneruskan kebudayaan tersebut.

Penyadaran terhadap masyarakat khususnya generasi muda sangat penting karena generasi muda adalah generasi pelanjut yang akan mewarisi dan melestarikan kebudayaan tersebut. Kini saat kita bersama-bersama berpangku tangan khususnya mayarakat Enrekang untuk menjaga kebudayaan dari nenek moyang kita dengan memberikan sosialisasi kepada anak-anak kita tentang pentingnya menjaga kesenian tersebut agar tidak punah.

Budaya bukan hanya merujuk pada sastra dan seni, tetapi juga pada keseluruhan cara hidup yang di praktikkan manusia dalam kehidupan sehari-hari. Salah satu bentuk kebudayaan adalah alat musik tradisional yang merupakan sarana pengiring lagu-lagu tradisonal yang dipentaskan dalam kegiatan-kegiatan adat, perkawinan ataukah sarana penghibur masyarakat. Musik Bambu (Bas) merupakan alat musik yang berasal dari daerah massenrempulu Enrekang dan cara memainkan alat musik tersebut dengan cara ditiup.

Musik bambu (bas) adalah sebuah kelompok musik bambu yang terdiri dari banyak pemain, meliputi perempuan dan laki-laki. Dalam permainan musik bambu mempunyai seorang dirgen untuk mengatur agar musik selaras dan harmoni. Instrument suling yang kecil biasanya dimainkan oleh kaum wanita sedangkan kaum laki-laki memainkan instrument yang besar. Dan sekarang ini, musik Bas mulai terusik keberadaannya, dikarenakan kurangnya minat pemuda sekarang untuk melestarikan hasil budaya yang menjadi warisan dari orang terdahulu kita agar tidak tergeser dengan budaya-budaya dari luar.

Generasi muda merupakan tongkat estafet penerus kebudayaan musik bas, melihat dari realitas yang sekarang ini bahwa kurangnya para generasi muda untuk mau melestarikan kesenian budaya khas Enrekang ini. Maka perlu adanya pembinaan sejak dini 
kepada generasi muda melalui sosialisai lingkup keluarga tentang penting menjaga warisan kebudayaan telah diturunkan secara turun temurun.

Melihat minimnya wadah untuk melestarikan kesenian khas Enrekang maka perlunya campur tangan pemerintah dalam melestarikan atau mengembangkan. Karena sangat di sayangkan ketika kesenian ini punah dan generasi kedepannya tidak akan merasakan lagi namanya musik bas yang menjadi ciri khas daerah enrekang tersebut.

Kebanyakan pemain musik Bas terdiri dari orang tua yang mempunyai kesibukan tersendiri, maka wajar kalau pemuda sekarang ini banyak yang tidak mengetahui cara memaingkan di karenakan para pemain musik bas tersebut sibuk akan urusan mencari nafkah keluarganya. Maka dari itu sepatutnya pemerintah memberikan kebijakan untuk kesejahteran bagi para pemain agar bisa membagikan ilmunya kepada generasi berikutnya .

Pementasan musik Bas akhir-akhir ini jarang sekali di pentaskan dikarena pergeseran budaya, yang dahulunya musik Bas pada saat acara adat, perkawinan dan perayaan-perayaan lain seringkali dipentaskan kini mulai jarang sekali ditemui. Maka perlu tindak lanjut pemerintah untuk mengangkat kembali kearifan lokal yang menjadi khas daerah enrekang seperti memberikan ruang untuk tampil pada saat pawai, HUT Indonesia, dan sebagainya. 


\section{Biodata Penulis}

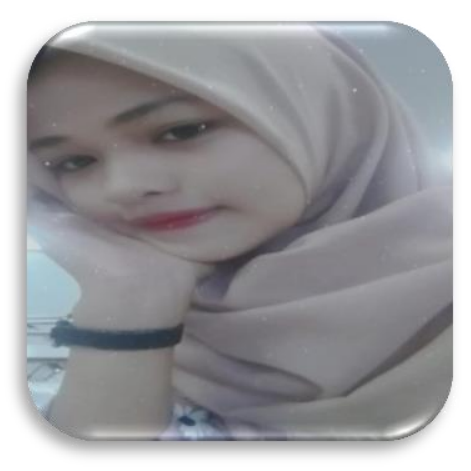

Siti Nurhalisa, Tempat, Tanggal Lahir di Kalimbu, 15 Mei 2000. Orang Tua: Roy Kuasa (Ayah) Jumiati (Ibu) Alamat Jln. Bukit Harapan. Pendidikan fomal : Sd 180 Kalimbua. MTSN Parepare. SMA 3 Parepare

Motto "Tetaplah hidup walaupun tidak berguna" 


\section{Mappasoro Sasi Budaya Mandar Lero}

Suku Mandar pada mulanya merupakan bagian dari provinsi Sulawesi-Selatan yang tergolong ke dalam empat suku/etnis besar di Sulawesi-Selatan yakni, suku Bugis, Makassar, Toraja, dan Mandar. Secara administratif suku Mandar saat ini telah terpisah namun dalam konteks budaya ia masih tetap tergolong ke dalam empat suku besar di Sulawesi-Selatan. Masyarakat Mandar terkenal sebagai nelayan dan pelaut yang ulung dan berani mengarungi lautan lepas, seperti halnya pelaut Bugis/Makassar.

Ujung Lero merupakan salah satu desa yang mayoritas warganya berasal dari suku Mandar. Akan tetapi, Ujung Lero ini berada di Sulawesi-Selatan bukan di Sulawesi-Barat. Maka dari itu, Ujung Lero sering dikenal sebagai Mandar Selatan. Ada banyak budaya di Ujung Lero ini diantaranya budaya, Mappasoro Sasi ini merupakan salah satu budaya yang dilaksanakan para nelayan sebagai tanda rasa syukur atas limpahan hasil laut yang ada di Ujung Lero ini.

Sementara di sisi lain, budaya ini mengalami modernisasi yang dahulunya merakit kapal-kapal kecil kemudian dihanyutkan ke laut tapi sekarang menjadi menggunakan kapal. Para nelayan kemudian dihiasi dan mengajak para warga ataupun pengunjung untuk naik di kapal. Kemudian diarak keliling lautan. Budaya ini dilaksanakan satu kali dalam setahun, kegiatan ini juga bukan merupakan perbuatan musyrik tapi bagian tanda rasa syukur para nelayan.

kegiatan ini pun mendapat respon baik dari pemerintah dan warga dari luar Ujung Lero yang datang menyaksikan atau meramaikan kegiatan budaya tersebut. Dalam budaya ini terdapat pesan tersendiri menurut masyarakat Lero tersebut yaitu sebagai tanda rasa syukur atas hasil laut serta sebagai rasa hormat kepada para penjaga laut dan untuk keselamatan para nelayan ketika di lautan mencari ikan.

Kebudayaan menjadi identitas dari bangsa dan suku bangsa. Maka disamping punya agama, seseorang biasa pula bagian dari 
suku tertentu. Suku tersebut memelihara dan melestarikan budayanya. Agama dan kesukuan juga biasa dinilai sebagai identitas primordial. Agama dan suku nyaris tidak berubah sepanjang hidup seseorang. Keduanya dimiliki dengan rasa fanatik karena keduanya diajarkan dalam mengarungi lautan kehidupan. Karena itu, ada yang mengkhawatirkan kalau keduanya menyatu dianggap akan berbahaya bagi kesatuan bangsa karena sama-sama dianut dengan fanatisme.

Bila hanya sifat fanatiknya yang disorot, kekhawatiran itu ada benarnya. Tapi agama, budaya dan adat suku bangsa tersebut mengandung ajaran tentang pandangan dan jalan hidup. Ajaran agama dan adat mengandung ajaran yang luhur, walaupun banyak yang tidak sejalan dengan pandangan hidup yang dianggap moderen. (Djoko Widaydho: 2015) Dalam pelaksanaan tradisi ini, seluruh nelayan akan menghias kapal mereka agar terlihat menarik, kemudian mereka akan melakukam konvoi di laut. Mereka juga menyediakan makanan untuk para warga yang ikut berpartisipasi dalam acara ini. Bahkan tidak jarang terdapat warga dari daerah lain yang turut memeriahkan acara.

Sebelum mempersilahkan masyarakat untuk makan hidangan yang telah mereka sediakan terlebih dahulu diadakan acara ma'baca. Makanan tersebut akan dibaca sebagai tanda syukur mereka, kemudian disisihkan sedikit untuk diturunkan ke laut. Dalam hal ini, masyarakat mempercayai bahwa tidak hanya manusia, tapi di laut juga terdapat makhluk Allah yang memiliki hak atas rezeki yang telah diberikan Allah kepada mereka. Setelah itu, mereka makan bersama di atas kapal.

"Di Mandar ada yang dikatakan budaya. Nah yang saya tanyakan itu tentang Mappasoro Sasi. Menurut bapak apa makna dari budaya Mappasoro Sasi itu pak?", tanya saya. "Secara bahasa, Mappasoro sasi berarti "memberi makan laut" atau lebih dikenal sebagai menaruh sesajen ke laut. Pada awalnya, budaya ini dilakukan dengan tujuan agar nelayan memperoleh hasil tangkapan yang banyak tapi bukan itu tujuan inti dari pelaksanaan ini melainkan adalah untuk melestarikan budaya yang sudah ada sejak dahulu. 
Dalam proses Mappasoro Sasi, yang harus diucapkan adalah sholawat kepada Nabi Muhammad SAW. Mappasoro Sasi itu awalnya berasal dari Nabi Musa a.s., karena beliau selalu menyerahkan makanan ke laut sebagai tanda Syukurnya kepada Allah SWT. Hal ini terjadi pada setiap hari sabtu dan karena laut lah Nabi Musa a.s. berhasil lolos dari kejaran fir'aun. Maka dari itu, budaya Mappasoro Sasi ada pada budaya Mandar ini", kata bapak hamal. (Wawancara Hamal)

Pelaksanaan acara baca doa syukuran biasanya dilakukan di rumah salah satu masyarakat yang telah mereka sepakati sebelumnya. Dalam prosesi ini juga diadakan pembacaan barazanji. Doa barazanji berisi tentang cerita dan kisah nabi Muhammad SAW, keluarga dan para sahabatnya, memberikan puji-pujian salawat kepadanya.

Dengan pembacaan barazanji akan tergambar kemuliaan akhlak, kasih sayang, kemurahan, ketaatan dan kesabaran nabi Muhammad SAW dalam beragama dan menegakkan agama Allah. Dengan segala harapan untuk masyarakat akan senantiasa mengenal dan tahu perihal pribadi beliau dan dapat menjadikannya suri tauladan utama dalam menjalani kehidupan kesehariannya.

Selain melakukan pembacaan doa syukuran bersama, dalam pelaksanaan budaya mappasoro sasi, masing-masing kapal juga harus menyediakan makanan untuk nantinya dimakan bersama di kapal. Untuk persiapan ini, masyarakat mengadakan acara ma'dawadawa Untuk menyiapkan makanan yang akan dibawa ke kapal, biasanya perempuan-perempuan di desa Lero akan memasak bersama. Kegiatan masak bersama dalam budaya mandar disebut dengan ma'dawa-dawa. Apalagi dalam budaya ini ada dua kali pelaksanaan baca syukuran. Biasanya, kegiatan ma'dawa-dawa dilaksanakan sehari sebelum pelaksanaan budaya mappasoro sasi.

Selain ma' dawa-dawa, masyarakat juga melakukan persiapan di kapalnya masing-masing. Para nelayan berlomba-lomba untuk menghias kapalnya hingga terlihat semenarik mungkin, biasanya mereka menghias kapal mereka dengan memasang umbul-umbul ataupun menggunakan bendera dari beberapa negara seperti bendera para pemain bola idola mereka tapi terdapat juga nelayan yang menyewa semacam hiasan seperti pada acara pernikahan 
karena menurut mereka hal itu jauh lebih praktis dan jauh lebih menarik.

Pada hari pelaksanaan budaya Mappasoro sasi, seluruh kapal akan berkumpul di pantai di Desa Lero kemudian mereka melakukan konvoi mengelilingi laut di sekitar desa Lero ataupun pare-pare. Setelah itu mereka mencari tempat yang menurut mereka aman untuk berlabuh. Biasanya mereka memilih pantai Lumpue, Parepare, untuk berlabuh. Kemudian mereka mengadakan doa syukuran di kapal masing-masing. Bagi nelayan yang menyediakan semacam sesajen, mereka akan memasukkan beberapa makanan ke dalam sebuah keranda mini kemudian menghanyutkan-nya ke laut, tapi ada juga yang sekedar membuang sedikit makanan ke laut. Dalam hal ini, masyarakat meyakini bahwa setiap rezeki yang diberikan oleh Allah SWT wajib diberikan juga untuk makhluk Allah yang lain. Mereka menaruh makanan ke laut karena mereka mendapatkan rezeki dari laut.

Kemudian, barulah mereka mengajak seluruh masyarakat untuk makan bersama. Dalam hal ini, makanan yang disediakan oleh masyarakat adalah termasuk makanan yang halal karena didapatkan dengan cara yang halal. Untuk pelaksanaan budaya mappande sasi, biasanya para nelayan akan mengajak seluruh kerabat mereka karena menurut mereka, semakin banyak yang diajak maka semakin baik bagi nelayan karena akan semakin banyak yang mendoakan mereka.

Bahkan tidak jarang terdapat masyarakat pendatang dari daerah lain yang ikut memeriahkan budaya ini. Mereka akan dengan senang hati menerima siapapun yang ingin ikut serta dalam tradisi ini selama tidak melebihi kapasitas muatan kapal mereka. Dalam hal ini, budaya Mappasoro sasi juga menjadi sarana untuk bersilaturahim antara sesama manusia.

Dan budaya ini menjadi salah satu sarana bagi masyarakat Lero untuk menjalin silaturahmi yang baik kepada sesama masyarakat ataupun sesama suku Mandar bahkan juga untuk menjalin hubungan kepada suku lain terutama suku Bugis yang sering hadir meramaikan dalam pelaksanaan kegiatan budaya ini, jadi kegiatan ini bukan hanya semata untuk memberi sesajen dalam 
artian memberikan sesuatu atas rasa syukur atas hasil limpahan laut ataupun untuk melestarikan budaya Mandar tapi juga kegiatan ini untuk menjalin silaturahmi yang baik.

Dalam budaya Mappasoro Sasi terdapat beberapa nilai-nilai, diantaranya adalah nilai gotong royong ( $\left.m a{ }^{\prime} d a w a-d a w a\right)$ dimana nilai ini tercipta akibat kerja sama ibu-ibu dalam membuat makanan untuk dimakan pada saat perayaan Mappasoro Sasi ini dan kerja sama para nelayan dalam mendekorasi kapal untuk para masyarakat, serta nilai silaturahmi untuk menambah keakraban para masyarakat, dan nilai akhlak terhadap Allah SWT yaitu bersyukur yakni ketika pembacaan doa.

Dalam Suku Mandar ada yang dikatakan Ussul (semacam mantra) atau bagian dari kepercayaan menurut masyarakat Mandar. Budaya Mappasoro Sasi ini menurut masyarakat di sini bukan merupakan sebuah kemusyrikan tapi ini merupakan budaya yang dibarengi dengan Ussul. Nah ketika menaruh sesajen ke dalam lautan itu bukan semata-mata supaya mendapatkan rezeki tetapi ini adalah pembagian rezeki kepada para penghuni laut, ketika menaruh makanan juga tidak asal menaruh tetapi juga dibarengi dengan ussul. Jadi budaya Mappasoro Sasi dilakukan untuk melestarikan budaya bukan bagian dari kemusyrikan. 


\section{Biodata Penulis}

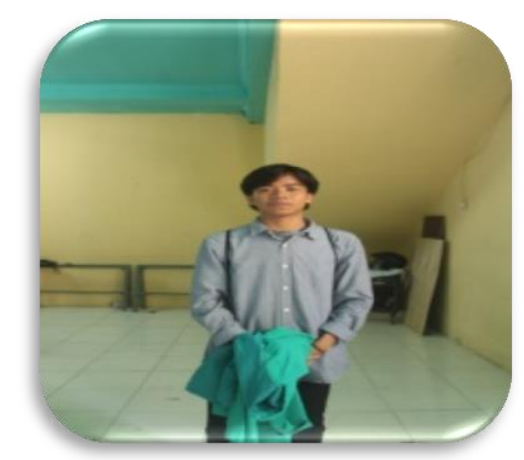

Ashar, lahir di Ujung Lero, 10 Maret 2000. Alamat Desa Ujung Lero, Kec. Suppa, Kab. Pinrang. Nama Orang tua Usman dan Masliah Pendidikan SDN 96 Pinrang / 2012. MTS DDI Lero / 2015. SMK Negeri 7 Pinrang/2018 Mahasiswa IAIN Parepare.

Motto "Jadikan Passion mu sebagai Prioritas mu 


\section{Tradisi Mappattuada}

Rasa saling menghargai dan menghormti akan tumbuh apabila antara sesama manusia menjunjung tinggi kebudayaan sebagai alat pemersatu kehidupan, alat komunikasi antar sesama dan sebagai ciri khas suatu kelompok masyarakat. Kebudayaan berperan penting bagi kehidupan manusia dan menjadi alat untuk bersosialisasi dengan manusia yang lain dan pada akhirnya menjadi ciri khas suatu kelompok manusia.

Pernikahan memang dianjurkan di dalam ajaran agama kita dan menjadi koadrat seorang insan yang telah mampu dan siap untuk membina rumah tangga dan hal tersebut pun di sunnahkan oleh baginda Rosulullah Muhammad Saw. Namun sebelum sampai kejenjang pernikahan dalam suku Bugis ada satu jenjang yang perlu dilalui sebelumnya yakni Mapettuada atau secara umum dikenal dengan julukan lamaran.

Namun bagaimana sebenarnya sejarah mapettuada dalam buda Budaya bugis ini mampu berkembang. Lalu bagaimana pula pandangan Islam terhadap mapettuada tersebut. Dan di balik keunikan kata dari mapettuada apa sebenaranya makna yang tersirat di dalamnya. Hal tersebutlah yang menajdi acuan dan landasan tulisan ini.

Mappettu artinya memutuskan, dan ada artinya perkataan, jadi mampettuada adalah perundingan antara utusan keluarga calon mempelai laki-laki dengan utusan keluarga calon mempelai perempuan. Hal ini merupakan tradisi atau adat Pernikahan Bugis yang dilakukan guna menetapkan tanggal pernikahan, dan mencocokkan serta menyepakati kembali pembicaraan saat prosesi lamaran sebelumnya.

Mappattuada ini bisa dikatakan sangat penting dan wajib ada dalam proses meminang sosok perempuan. Mappettuada dihadiri keluarga atau utusan calon mempelai lelaki di kediaman calon mempelai perempuan. Dalam Prosesi Mappettuada akan disuguhkan bebagai macam kue tradisional Bugis yang disiapkan oleh keluarga 
calon mempelai perempuan atau yang dibawa oleh keluarga calon mempelai laki-laki.

Dari setiap suku tersebut memiliki adat dan kebudayaan yang hampir mirip, seperti tradisi pernikahan suku Bugis dan suku Makassar. Dan pernikahan memang dianjurkan di dalam ajaran agama kita dan menjadi koadrat seorang insan yang telah mampu dan siap untuk membina rumah tangga dan hal tersebut pun di sunnahkan oleh baginda Rosulullah Muhammad Saw. (https://arsip.simpulrakyat.co.id)

Mapettuada, begitu masyarakat bugis menyebutnya. Tradisi yang dilakukan dalam prosesi lamaran adat bugis. Mappetu artinya memutuskan. Ada artinya perkataan. Sehingga secara harfiah prase kata ini jika digabungkan memiliki maknanya sendiri sebagai suatu prosesi pengambilan kesimpulan dari bahasan yang dilakukan dalam prosesi lamaran antara pihak laki-laki dengan pihak perempuan. Prosesi ini adalah hal yang sangat penting. Hal itu dikarenakan dalam prosesi inilah dilangsungkan lamaran; pernyataan formal keluarga pihak laki-laki yang datang kepada pihak perempuan. Dalam prosesi inilah ditetapkan diterimanya lamaran, penentuan hari pernikahan serta mahar yang akan ditebus untuk mempelai perempuan (https://arsip.simpulrakyat.co.id)

Pada acara mapettuada akan dihadiri oleh keluarga laki-laki yang datang, yang dipercayakannya sebagai juru bicara dan pengambil keputusan. Lalu di pihak perempuan telah menunggu orang yang menjadi wali nikah bagi si perempuan minimal satu orang yang hadir. Di acara ini disuguhkan kue-kue tradisional bugis yang disiapkan oleh keluarga calon mempelai perempuan ataupun biasa dibawa dari keluarga calon mempelai laki-laki.

Namun hal yang juga penting diketahui adalah masa pra kondisi sebelum adanya acara mappettuada ini. Yakni adanya informasi sebelumnya yang diberikan oleh ke dua pihak. Hal yang paling sering dilakukan adalah jika seorang laki-laki ini mempunyai maksud menikah perempuan yang disukainya maka sang lelaki akan menanyakan dulu kondisi status dari si perempuan.

Bisa lewat keluarganya atau orang terdekat yang dipercaya. Kadang pesan pertanyaan itu tersirat lewat pertanyaan yang hanya 
dimengerti oleh mereka yang paham. Contohnya 'matasani wita buah panasa na ambona la becce' (sepertinya sudah bisa dipetik buah nangka milik bapaknya si gadis). Kata bisa dipetik buah nangka disini dipahami sebagai pesan tersirat akan keinginan mempersunting si perempuan. Kemudian akan dilanjutkan kalimat 'wedding mua ro ukadang nakko deppa ga mallaui' (mungkin saya bisa mendapatkannya kalau belum ada yang meminta). Pesan yang tersirat itulah yang akan dibalas oleh keluarga/wali perempuan dengan persetujuan atau penolakan.

Dalam prosesi inilah dikenal falsafah kalimat 'aja ki ma'duta rekko de' itarimaki' (jangan datang melamar jika tidak diterima). Hal ini adalah pesan agar kerukunan keluarga dalam bugis tetap terjalin baik. Karena jika tidak diawali dengan proses pra kondisi ini menuju tahap mappetuada maka akan sangat rentan terjadi penolakan yang akan membuat malu keluarga laki-laki yang hadir. (https://badikinstitute.blogspot.com)

Prosesi mappettuada' umumnya dirangkaikan dengan mappasierekeng yang tidak lain adalah membahas kesimpulan mengenai kesepakatan yang telah dibicarakan bersama dengan seluruh prosesi lanjutan dari rangkaian prosesi lamaran suku bugis. Pada prosesi Mappettuada akan dibicarakan segala sesuatu mengenai hal-hal yang prinsip. Hal ini sangat penting karena akan dijadikan sebagai dasar dari kesepakatan yang akan dilakukan bersama kemudian dikuatkan kembali dengan pengambilan keputusan final yang disebut mappasierekeng.

Sebuah cincin emas dari pihak pettenre' yakni dari pihak lakilaki akan menyerahkan sebuah cincin emas sebagai simbol pengikat atau passio beserta beberapa simbol atau harapan sebagaimana adat suku bugis dalam kehidupan lainnya. Jika Waktu antara pernikahan yang diberikan akan dilaksanakan dalam waktu singkat, maka prosesi mappettuada akan disertai dengan passuro mita atau serah terima seluruh kesepakatan yang telah diberikan sebelumnya terutama doi paenre (bugis) atau doe panai (http://anassalehe.blogspot.com)

Merujuk pada pedoman tradisi pendahulu yang terwariskan dalam hal pelaksanaan perkawinan yang sebagiannya berasimilasi dengan ajaran Islam, sehingga jelas bahwa di dalamnya terkandung nilai-nilai atau unsur sarak. Ini dapat dilihat mulai dari tahap 
mammanu'manu, madduta, mappettuada, mappacci, tudangbotting dan marolah, yakni tahap lamaran, pertunangan, jenjang perkawinan, resepsi perkawinan, pertemuan keluarga setelah resepsi, dan seterusnya.

Tahap lamaran dalam perkawinan bagi masyarakat Bugis dimulai dari penjajakan hal ini tentu memiliki unsur sarak bila dikaitkan riwayat hadis yang terdapat dalam Muslim sebagai berikut: Dari Abī Hurairah ra berkata, ketika saya di sisi Nabi saw, beliau didatangi seorang laki-laki dan menyatakan hendak menikahi seorang perempuan dari golongan Ansār, lalu Nabi saw bertanya, apakah engkau telah melihat perempuan tersebut. Jawabnya, belum. Maka Nabi saw memerintahkannya agar terlebih dahulu melihat perempuan yang akan dinikahinya .... (HR. Muslim)

Hadis tersebut sebagai dasar pentingnya tahap lamaran sebagaimana yang telah mentradisi dalam adat masyarakat Bugis. Setelah itu dilanjutkan dengan acara pertemuan untuk lamaran yang disebut maddúta sebagai proses peminangan ini menunjukkan nilai keagamaan yang berdimensi silaturrahim dan memposisikan perkawinan sebagai upaya penghargaan kepada perempuan. Oleh karena perkawinan adalah sebuah anugerah kemuliaan yang diberikan Allah swt kepada manusia, maka perkawinan haruslah dilakukan dengan segala norma yang berlaku meliputi norma adat, norma agama/syariat, dan aturan atau norma kenegaraan. Karena perintah perkawinan sangat urgen, maka konsekuensinya adalah berimbas kepada hal-hal yang berkaitan dengannya.

Setelah lamaran diterima dilanjutkan dengan pertemuan berikutnya yang disebut mappettuada, tujuannya adalah membicarakan langkah-langkah yang akan ditempuh pada tahap selanjutnya yakni, tahap pertunangan. Yang demikian ini, sejalan pula dengan unsur sarak karena ajaran Islam sangat mementingkan musyawarah dan negosiasi.

Tahap pertunangan merupakan proses pemantapan yang disebut mappasiarékeng, dan di sini dibuat kesepakatan antara pihak mempelai laki-laki dan perempuan tentang hari jadi perkawinan yang disebut mattanraesso. Dalam menentukan hari " $\mathrm{H}$ " perkawinan masyarakat Bugis pada umumnya masih percaya pada hari-hari dan 
tanggal keberuntungan, dan waktu yang baik untuk melangsungkan akad nikah. (http://skiadabhumaniora.blogspot.com)

Masyarakat Bugis, tentu mengenal banyak Tradisi dalam Pernikahan salah satunya "Mappettuadd". Mappettuada biasanya dilakukan setelah lamaran atau "Lettu" dalam bahasa bugis. Mappettu artinya Memutuskan, dan Ada artinya Perkataan, jadi Mampettuada adalah perundingan antara utusan keluarga calon mempelai laki-laki dengan utusan keluarga calon mempelai perempuan. Hal ini merupakan tradisi atau adat Pernikahan Bugis yang dilakukan guna menetapkan tanggal pernikahan, dan mencocokkan serta menyepakati kembali pembicaaraan saat prosesi lamaran sebelumnya.

Mappettuada dihadiri keluarga atau utusan calon mempelai lelaki di kediaman calon mempelai perempuan. Dalam Prosesi Mappettuada akan disuguhkan bebagai macam kue tradisional khas Bugis yang disiapkan oleh keluarga calon mempelai perempuan atau yang dibawa oleh keluarga calon mempelai laki-laki.

Semoga tradisi mapettuada terus dilestarikan oleh kalangan pemuda suku bugis. Agar tradisi ini tetap menjadi kebiasaan turuntemurun yang masih kental sebagai ciri khas masyarakat bugis dalam melangsungkan prosesi pernikahan. Sebab beberapa budaya akan sirna jika masyarakatnya tidak mampu melestarikannya dengan baik sehingga menghilngkan ciri khas dari suatu daerahnya masingmasing.

Berdasarkan uraian di atas maka diperoleh kesimpulan sebagai berikut: mapettuada merupakan tradisi lamaran suku Bugis. Mappettu artinya Memutuskan, dan Ada artinya Perkataan, jadi Mampettuada adalah perundingan antara utusan keluarga calon mempelai laki-laki dengan utusan keluarga calon mempelai perempuan. Hal ini merupakan tradisi atau adat pernikahan bugis yang dilakukan guna menetapkan tanggal pernikahan, dan mencocokkan serta menyepakati kembali pembicaraan saat prosesi lamaran sebelumnya. Mapatteuada memang menjadi hal yang penting bagi masyarakat bugis sebelum melanjutkan kejenjang pernikahan.

Prosesi mappettuada' umumnya dirangkaiankan dengan mappasierekeng yang tidak lain adalah membahas kesimpulan 
mengenai kesepakatan yang telah dibicarakan bersama dengan seluruh prosesi lanjutan dari rangkaian prosesi lamaran suku bugis. Intinya mapettuada sama halnya dengan prosesi lamaran dalam suku bugis. Dan hasil dari pembicaraan dalam proses mapettuadalah yang menjadi acuan langkah selanjutnya dalam prosesi pernikahan suku bugis. 


\section{Biodata Penulis}

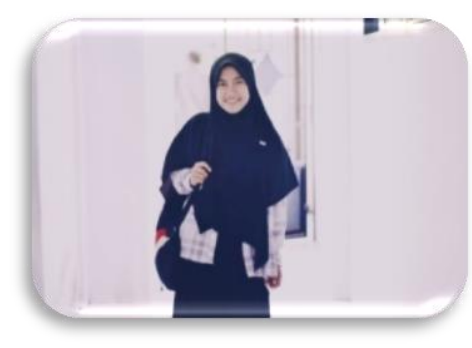

Hestiana. Motto: "Lakukan apa yang terbaik dan kau akan menuai hasil yang terbaik pula". Lahir di Enrekang 11 April 2000. Ia adalah mahasiswa dari Institut Agama Islam Negeri (IAIN) Parepare, dengan program studi (prodi) Jurnalistik Islam. Lahir dari orang tua bernama Hasanuddin (ayah) dan Subeda (ibu), sebagai anak pertama dari lima bersaudara. Penulis menempuh pendidikan mulai dri TK (Taman kanak-kanak) di Enrekang lalu SDN 198 Batulappa Pinrang. (lulus tahun 2012), melanjutkan ke SMPN 2 Enrekang (lulus tahun 2015), dan kemudian melanjutkan pendidikan di SMAN 10 Luwu (lulus tahun 2018), hingga akhirnya bisa menempuh masa kuliah di Fakultas Ushuluddin, Adab dan Dakwah IAIN Parepare, Kota parepare, Sulawesi Selatan. Karena keaktifannya semasa sekolah ia menjadi pengurus osis semasa SMP. Juga kembali menjadi pengurus osis saat SMA dan pernah menjabat sebagai sekertaris osis pada masa jabatannya. Karena kesenangannya terhadap puisi sehingga ia aktif dalam menciptakan beberapa puisi dan dimuat pada akun media sosialnya. Takjarang ia turut serta dalam mengikuti bebrapa lomba cipta dan baca puisi yang ada di beberapa daerah sulawesi. Ia aktif di beberapa organisasi kemahasiswaan baik intra maupum ekstra kampus seperti PMII (Pergerakan Mahasiswa Islam Indonesia), LIBAM (Lintasan Imajinasi Bahasa Mahasiswa) dan selaku ketua HM-PS program study Jurnalistik Islam saat ini. Ia juga pernah menjadi salah satu member dalam organisasi kerelawanan yakni ACT (Aksi Cepat Tanggap) yang bergerak sebagai Volunteer kemanusiaan juga pernah menjadi salah satu anggota HMJ (Himpunan Mahasiswa Jurusan) pada masanya. 


\section{Tradisi Sayyang Pattuddu di Masyarakat Suku Mandar}

Budaya adalah suatu cara hidup yang berkembang dan dimiliki bersama oleh sebuah kelompok orang dan diwariskan dari generasi ke generasi. Menurut Effat Al-Syarqawi budaya adalah suatu khasanah dari sekelompok masyarakat yang tercermin pada kesaksian dari berbagai kehidupan. Salah satu budaya yang ada di Indonesia yaitu Sayyang Pattuddu di Desa Lapeo yang dilakukan saat masih menjadi bagian kerajaan Balanipa. Namun saat ini Lapeo merupakan salah satu daerah di Kecamatan Campalagian Kabupaten Tinambung Balanipa Sulawesi-Barat.

Sayyang adalah kuda dan patuddu artinya menari, maka artinya adalah kuda menari. Masyarakat mandar meyakini tradisi Sayyang Patuddu dan khatam Al-quran memiliki pertalian yang sangat erat antara yang satu dengan yang lainnya. Sebab tradisi Sayyang Patuddu digelar untuk mengapresiasi anak yang telah menamatkan Al-quran.

Berdasarkan hasil wawancara dengan masyarakat suku mandar, masyarakat suku Mandar ada yang menggelar Sayyang pattuddu dalam setahun sekali, dan ada yang menggelar dua tahun sekali, itu sesuai dengan ketetapan daerah masing-masing. Meskpun ada perbedaan dengan waktu pelaksanaan tetapi cara menggelar tradisi sayyang pattuddu ini tetap dengan cara yang sama.

Ada beberapa kearifan budaya suku mandar yaitu salah satunya Sayyang Patuddu. Budaya Mandar adalah budaya yang ada di provinsi Sulawesi-Barat. Masyarakat Mandar melestarikan dari turun-menurun tradisi Sayyang Pattuddu. Meskipun demikian, sebagian daerah telah mencampur dengan peningkatan budaya saat ini. Akan tetapi nilai-nilai yang terkandung dalam tradisi ini tidak hilang.

Masyarakat Suku Mandar, ia mengatakan "Diappa to tamma' mambaca Al-Qur'an Na Mala Di Sanga Mindai Sayyang Pattu'du', Mitttama Pai Wattu Pammunuang". Dengan arti "Adapi orang yang tamat baca Alquran baru bisa naik sayyang pattu'du' atau kuda 
menari, kapan di gelar ketika bulan pammunuang atau bulan maulid".

Dengan demikian, Sayyang Pattuddu adalah Kuda Menari yang di gelar ketika seorang anak telah menamatkan Al-quran dan dilaksanakan ketika bulan maulid. Seiring berkembangnya zaman, bukan hanya anak-anak yang sudah khatam Alquran ikut dalam pergelaran tradisi ini, tetapi tradisi ini juga dapat digelar oleh para tokoh masyarakat lainnya untuk penjemputan para wisatawan tamu yang masuk di daerah Mandar, dan juga digelar ketika acara pernikahan.

Azis Syah bahwa setelah Islam mulai masuk dan berkembang dipertengahan masyarakat Balanipa atau kerajaan Balanipa pada abad ke-17 pada masa pemerintahan Kakana I Pattang dan pada masa itu Islam telah menjadi agama Resmi kerajaan. Keberadaan masjid di Desa Lapeo menjadi salah satu bukti kedatangan Islam saat itu yang berfungsi sebagai tempat ibadah dan sebagai tempat musyawarah masyarakat. Hal tersebut memberikan isyarat bahwa Islam yang dibawah oleh para tokoh ulama pembaharu dalam nuansa ke-Islaman di Mandar tidak hanya bersifat politik, tetapi juga merambak ke lingkup sosial budaya masyarakat. Setelah Islam masuk, kuda kemudian dididik, dilatih, sekaligus menjadi alat pendidikan.

Bagi putra bangsawan, sangat keharusan untuk pandai berkuda. Demikian dengan para santri, ahli dalam berkuda harus bisa karena sebagai tolak ukur untuk cepat menamatkan Al-quran. Dengan begitu para santri melatih dan mendidik kuda agar pandai mengikut dalam lantunan sholawat dan rebana. Sejak saat itu, Sayyang Pattuddu dikenal di kalangan bangsawan dan dilestarikan.

Dalam atraksi Sayyang Pattuddu, kuda akan bergoyang dan bergerak mengikuti lantunan rebana. Di atas punggungnya duduk seorang gadis baik anak-anak, salah satu lutut kaki agak ditegakkan dan tangan ditopangkan di atasnya sambil memegang kipas. Kaki lainnya ditekuk ke belakang dengan lutut menghadap ke depan.

"Anna iyya de ee nanaeke ee diannai daii sayyang pattu'du dibawa mappinggulilingii kappung anna naitai lao masyarakat. Anna iyya re e sayyang pattudu rapangi dibei semanga lao nanaeke supayaa cinappa i mattammai A/-quran". Artinya, seorang anak yang 
telah khatam bacaan Qur'an akan diupacarakan dengan menunggangi Sayyang Pattudduq dan diarak keliling kampung untuk disaksikan oleh masyarakat. Sayyang Pattudduq pun juga menjadi motivasi bagi anak-anak untuk segera menamatkan Al Qur'an.

Kuda yang telah dilatih untuk pergelaran Sayyang Pattuddu akan dihias seindah dan menarik. Begitu juga dengan orang yang menunggang kuda tersebut, akan dihias dengan menggunakan baju Pokko dan lengkap dengan aksesorisnya, itu diperuntukkan untuk anak perempuan. Sehingga pakaian anak laki-laki menggunakan pakaian Haji yaitu sorban. Tetapi kebanyakan anak perempuan yang ikut dalam tradisi ini. Dimulai nya syair sholawat dan pukulan rebana berbunyi, sang kuda mulai menghentak-hentakkan kaki, menggoyangkan kepalanya, dan sekali-kali kuda mengangkat setengah badannya sambil mengeluarkan suara kudanya.

Suara gemerincing dari hiasan kuda berpadu dengan hentakkan kaki kuda dan pukulan rebana yang semakin kuat membuat kuda menjadi lebih semangat dan penonton juga ikut menikmati keindahan kearifan budaya Sayyang Pattuddu ini. Salah satu masyarakat mengakatan "Yah itta dini mandar mua diang bomo sayyang pattudu..itta di e masyarakat e tatta tau mario apa iyya rio sayyang pattudu tradisinna Mandar anna napasiolai rabana macoa sannal i diirranni mua napasipparai tuttunaa..poko na de ew mua diang bomo totamma alquran tatta i tau mario". Artinya, Yah kami juga di sini kalau ada lagi sayyang pattu'du' kami masyarakat sangat senang karena itu adalah tradisi dibarengi dengan musik rebana sehingga perpaduan antara kuda dan rebana sangat cocok pokok nya kami senang ketika ada orang yang khatam.

Untuk mengontrol kuda, ada seorang laki-laki yang sebagai penuntun kuda dan sekaligus pemberi arahan kepada kuda yang disebut dengan sawi. Empat orang sebagai pendamping disebut Passarung, masing-masing dua orang disamping kanan dan dua orang disamping kiri kuda bertugas menjaga kestabilan penumpang.

Sayyang Pattudu adalah bahasa Mandar yang artinya Kuda Menari. Sayyang Pattuddu biasa dilaksanakan dalam dua tahun sekali diperuntukkan untuk anak-anak maupun semua kalangan masyarakat. Seiring dengan perkembangan zaman, budaya tradisi 
Sayyang Pattuddu bukan hanya sebagai tradisi khatam Al-quran, baik dengan acara nikahan dan acara penjemputam tamu. Kuda yang ditunggangi harus dengan kuda yang telah terlatih, sehingga kuda tersebut dapat menari dengan iringan rebana atau lantunan sholawat. Saat rebana dimainkan atau lantunan sholawat kuda akan menghentak-hentakkan kakinya dan mengangguk-angguk kepala dan sesekali mengangkat setengah badannya di udara.

Kita ketahui bahwa Sayyang Pattudu adalah tradisi budaya suku Mandar yang dari masa nenek moyang dan hingga sekarang banyak yang pergeserang waktu pelaksaan tetapi tetap dilakukan. Untuk menjaga kearifan lokal suku Mandar ini, kita meyakini bahwa tradisi ini sebagai ajang positif terhadap semua kalangan masyarakat. Meskipun di suku Mandar terdapat banyak daerah seperti Kabupatan/Kota, dan kecematan. 


\section{Biodata Penulis}

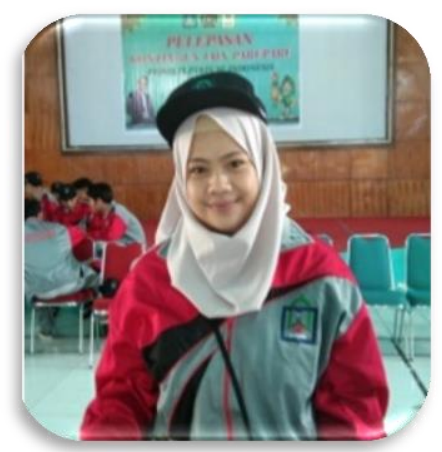

Feby Amalia. Lahir di Kota Parepare, pada tanggal 7 Februari tahun 2000. Anak pertama dari tiga bersaudara. Lahir dari keluaraga yang sederhana, dari pasangan Hasnawi dan I Sappe. Tinggal di Kota Parepare, beralamat Jalan Matalie, Kecamatan bacucuki Barat, Kelurahan Lumpue. Pendidikan yang telah ditempuh yaitu TK Pertiwi Kota Parepare, SD Negeri 65 Parepare, SMP Negeri 1 Parepare, SMK Negeri 1 Parepare, dan sementara menenpuh pendidikan S1 Prodi Jurnalistik Islam di IAIN Parepare. Hobby yang dari dulu di geluti sejak dari SD sampai sekarang yaitu Tennis meja.

Motto: "Hidup itu butuh perjuangan, maka jangan siasiakan kesempatan yang ada" 


\section{Menre' Bola}

Tradisi menre' bola baru merupakan sebuah kegiatan ritual adat dalam rangka memasuki rumah baru. Ritual ini dilaksanakan sebagai pengungkapan rasa syukur kepada sang pencipta atas berkat rahmat dan taufik-Nya. Upacara menre' bola baru dalam konteks ini dapat dilihat dari bentuk simbolik kehidupan manusia dan melalui upacara-upacara tersebut dapat diketahui makna simbolik upacara itu sendiri dan benda-benda serta lambang-lambang yang dipergunakan dalam upacara.

Keunikan dalam upacara menre' bola karena adanya nilai kearifan lokal yang merupakan falsafah hidup masyarakat. Kearifan lokal merupakan suatu istilah yang mencuat ke permukaan dengan mengahdapi prinsip, nasehat, tatanan, norma, dan perilaku leluhur masa lampau yang masih urgen untuk diaplikasikan dalam menata berbagai fenomena yang muncul.

Upacara menre bola baru mempunyai aturan tersendiri, bahkan boleh jadi kearifan lokal yang dimiliki dalam upacara memiliki relevansi dengan nilai ke-Islaman. Kearifan lokal pada upacara menre' bola baru ternyata sangat berpengaruh pada kehidupan keseharian mereka, mengingat setiap kearifan memiliki nilai tersendiri.

Tradisi menre' bola baru merupakan sebuah kegiatan ritual adat dalam rangka memasuki rumah baru. Ritual ini dilaksanakan sebagai pengungkapan rasa syukur kepada sang pencipta atas berkat rahmat dan taufik-Nya.

Menre bola adalah budaya lokal masyarakat Bugis, ketika sebuah keluarga akan memasuki atau pindah ke rumah baru terdapat serangkaian upacara adat yang harus dijalankan, akan tetapi sebelum menre bola ada serangaian kegiatan yang mendahului, mulai saat persiapan bahan-bahan untuk membangun rumah, ketika rumah akan dibangun atau didirikan, juga ketika rumah tersebut siap untuk ditinggali, bahkan saat rumah tersebut sudah dihuni. Bagi orang bugis menre' bola adalah simbol kehidupan. 
Menre bola adalah budaya lokal masyarakat Bugis, ketika sebuah keluarga akan memasuki atau pindah ke rumah baru terdapat serangkaian upacara adat yang harus dijalankan, akan tetapi sebelum menre bola ada serangkaian kegiatan yang mendahului, mulai saat persiapan bahan-bahan untuk membangun rumah, ketika rumah akan dibangun atau didirikan, juga ketika rumah tersebut siap untuk ditinggali, bahkan saat rumah tersebut sudah dihuni.

Bagi orang bugis menre' bola adalah simbol kehidupan. Simbol itu mencerminkan harapan, kejayaan, masa depan, semangat dan harmoni, karena itu menre' bola selalu diawali dengan ritual yang tidak boleh diabaikan sekaligus sebagai tanda kesyukuran atas anugrah rumah yang telah dianugrahkan. Adapun langkah-langkah yang dilakukan dalam upacara menre' bola yaitu:

Pertama, sebelum acara menre' bola baru terlebih dahulu diadakan musyawarah dan memanggil orang pintar atau sanro untuk meminta pendapat tentang hari yang baik untuk melaksanakan upacara menre' bola baru. Adapun waktu yang baik yang biasanya dipilih oleh sanro atau orang pintar itu adalah hari senin atau hari jumat. Menurut salah satu sumber, "Iyya wettu magelloe ripegau menre' bola yanaritu onni seneng yarega onni juma'. Nasaba wettu aseneng narijajiangngi Nabitta, nai nappa wettu juma' ipancajiwi nabi Adam." Waktu yang paling baik untuk mengadakan upacara ini adalah malam senin atau malam jum'at. Karna pada hari senin Nabi Muhammad saw. dilahirkan dan Nabi Adam a.s. dilahirkan pada hari jum'at.

Kedua, sebelum pemilik naik ke rumah, keluarga dan pemilik harus mengelilingi rumah terlebih dahulu dengan bimbingan dari sanro bola. Proses mengelilingi rumah ini dilakukan dari depan tangga rumah kemudian mengelilingi rumah searah orang tawaf. Dalam ritual ini ada dua hal yang dilakukan yaitu mappasili, menyiapkan daun pasili. Mappasili dilakukan dengan cara daun passili ditaruh pada wajan atau wadah berisi air yang sebelumnya telah disiapkan atau dilafazhkan bacaan tertentu. Mappassili diawali dengan membacakan doa-doa oleh sanro bola dan diakhiri dengan surat Al-Fatihah. 
Biasanya sebelum keluarga naik ke rumah sanro bola akan terlebih dahulu naik, kemudian diikuti pemilik rumah dan keluarganya. Mabbarasanji merupakan hal yang paling lazim di dalam adat bugis. Biasanya barasanji akan dilakukan pada acara-acara tertentu termasuk salah satunya menre' bola. Masyarakat memahami Barzanji sebagai sesuatu yang sakral dan wajib dilakukan ketika melaksanakan suatu upacara adat. Tanpa Barzanji suatu upacara adat dikatakan belum sempurna. Bagi mereka, Barzanji merupakan penyempurna dari upacara adat yang mereka lakukan.

Maccera bola adalah upacara ritual tambahan yang dilakukan setelah menre' bola. Maccera bola sendiri memiliki arti yaitu mempersembahkan sesuatu kepada rumah. Biasanya yang dipersembahkan adalah hewan hewan kurban seperti ayam, sapi, domba, atau kambing. Tujuannya yaitu untuk perlindungan keselamatan bagi penghuni rumah dan terhindar dari malapetaka dan gangguan roh jahat yang berada di dalam rumah.

Empat langkah di atas harus dilakukan semua dan tidak boleh ada yang terlewatkan, sebab menurut kepercayaan orang bugis jika langkah langkah diatas ada yang terlewatkan maka penghuni rumah akan merasa tidak tenang akibat gangguan roh roh dan makhluk makhluk jahat. Terutama maccera bola, menurut kepercayaan jika upacara maccera' bola ini tidak dilaksanakan maka orang tersebut tidak boleh sama sekali menyembelih hewan, baik pada waktu mengadakan acara di rumahnya, pada waktu lebaran begitu pula pada hari raya qurban. Begitu sakralnya upacara menre' bola ini.

Dalam upacara menre' bola terdapat dua tradisi yang biasa dilihat yaitu tradisi Islam dan Tradisi Pra Islam. Di satu sisi, terdapat nilai ajaran Islam yang bisa kita realisasikan, namun disisi lain terdapat segelintir praktik-praktik yang tidak sesuai dengan ajaran Islam. Adapun praktek-praktek yang dimaksudkan adalah sebagai berikut:

Pertama, dalam upacara menre' bola masyarakat mempercayai akan adanya malaikat atau roh yang melindungi rumah. Dengan adanya kepercayaan ini, maka pemilik rumah memanggil sanro' bola untuk membimbing mereka dalam menata rumah agar selamat dari gangguan roh-roh jahat. Memberikan mereka sesajen agar terhindar dari bahaya. Dalam ajaran Islam pun mengakui adanya jin dan 
malaikat, tetapi bukan untuk disembah. Memberikan sesajen dinilai memberikan persembahan kepada roh-roh sehingga bertentangan dengan agama.

Kedua, dalam upacara menre' bola, ditampilkan ritual-ritual penolak bala seperti; berputar mengelilingi rumah, mappassili, mabbedda' bola dan maccera' bola. Dengan melaksanakan ritual tersebut, maka rumah akan jauh dari bencana atau menjauhkan dari roh-roh jahat. Ritual tolak bala' tersebut dipaksakan untuk mendapat tempat terhormat yaitu diposisikan sebagai tradisi warisan luhur nenek moyang atau sebagai budaya bangsa yang harus dilestarikan, dan sebagainya. Ritual-ritual semacam ini berpotensi memunculkan nilai kemusyrikan yang tidak sejalan dengan ajaran Islam. Dalam Islam, memohon perlindungan dari gangguan roh-roh jahat atau malapeta hanya kepada Allah swt.

Ketiga, maccera' bola artinya proses penyembelian hewan yang dipersembehkan kepada pangonroang bola. Hal ini tidak sejalan dengan aqidah Islam yang termaktub dalam al-Qur'an dan Hadis. Bahkan perbuatan tersebut merupakan perbuatan syirik besar yang biasa menyebabkan pelakunya keluar dari Agama Islam (menjadi kafir).

Menurut penulis ada beberapa langkah langkah agar menre bola ini tidak menyimpang dalam aturan agama tanpa harus menghapus kearifan lokal budaya tersebut yaitu: Meniatkan semua ritual ini hanya kepada Allah SWT. Adapun beberapa ritual yang dianggap menyesatkan sebaiknya di jelaskan terlebih dahulu kepada masyarakat awam tujuan upacara itu diadakan. Agar nanti yang mewarisi budaya ini tidak salah kaprah dengan tujuan diadakan upacara. jika memang masih terjadi kesalahpahaman, sebaiknya ritual yang dianggap mengandung kecurigaan diganti menjadi ritual yang lain yang lebih baik dan sesuai anjuran agama. Contohnya pada mappasili, dilakukan dengan pegajian di dalam rumah.

Memang mengganti ritual akan sangat susah apalagi jika sudah turun-temurun namun tentu saja lebih baik daripada melanggar aturan agama. Menre bola adalah budaya lokal masyarakat Bugis, ketika sebuah keluarga akan memasuki atau pindah ke rumah baru terdapat serangkaian upacara adat yang harus 
dijalankan, akan tetapi sebelum menre bola ada serangaian kegiatan yang mendahului, mulai saat persiapan bahan-bahan untuk membangun rumah, ketika rumah akan dibangun atau didirikan, juga ketika rumah tersebut siap untuk ditinggali, bahkan saat rumah tersebut sudah dihuni.

Adapun rangkaian yang harus ada dalam upacara menre bola yaitu menentukan hari baik, berputar mengelilingi rumah, menre' bola, mabbarasanji, dan maccera' bola. Semua bagian-bagian ini memiliki arti khusus yang membuat tradisi ini unik.

Maka dari itu sebagai orang bugis marilah kita mempertahankan tradisi yang kita punya agar tidak menghilang atau dilupakan masyarakat. 


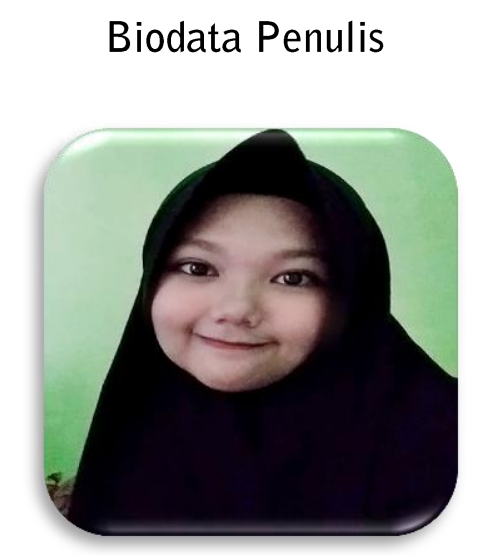

Faikatul Hikmah, Tempat Tanggal Lahir Woddi, 30 Juni 2000. Alamat: Woddi, desa Watu Toa, Kec. Marioriwawo, Kab. Soppeng Motto: "Jalani saja apa yang telah digariskan" 


\section{Mappasikkarawa dalam Sudut Pandang Islam}

Pernikahan menjadi salah satu bagian terpenting dalam kehidupan, karena pernikahan merupakan Sunnah Rasulullah Muhammad Saw. Indonesia begitu kental dengan adat istiadatnya, tak jarang adat istiadat disejajarkan dengan perintah agama, wajib hukumnya diikuti, bahkan sebagian ada yang mendahulukan adat daripada tuntunan agama yang mereka anut. Kebanyakan masyarakat yang lahir dari suku atau daerah memang hidup mendarah daging dengan ajaran nenek moyang.

Dalam pernikahan masyarakat Bugis, ada berbagai macam ritual yang perlu dilaksanakan, diantaranya mappasikarawa. Mappasikarawa yang berarti saling menyentuh ini merupakan proses sakral sekaligus menjadi simbol bagi kedua mempelai bersentuhan untuk pertamakali sebagai suami-istri yang sah.

Pemahaman makna mappasikkarawa dalam suku Bugis sering dikaitkan sebagai penentu hubungan kedua mempelai dalam mengarungi bahtera rumah tangga kedepannya. Sementara keberhasilan rumah tangga bisa diukur dari bagaimana pasangan menjalankan hubungan setelah pernikahan, tentunya hal ini berkaitan dengan cara komunikasi kedua pihak. Oleh karena itu untuk menghindari kesalapahaman serta meluruskan makna sebenarnya dari mappasikarawa hal ini lebih penting untuk diteliti lebih lanjut.

Berdasarkan uraian di atas maka ada beberapa yang menjadi pertanyaan: (1) Makna yang terkandung dalam tradisi mappasikarawa; (2) Kedudukan mappasikarawa dengan kehidupan kedua pengantin; (3) Hubungan mappasikarawa dengan Islam.

Mappasikarawa berasal dari dua suku kata yaitu mappa dan sikarawa. Menurut bahasa, mappa yang berarti imbuhan ber-. Sementara sikarawa berarti saling menyentuh, atau sederhananya mappasikarawa artinya bersentuhan.

Setelah ijab qabul mempelai laki-laki diarahkan menuju kamar mempelai wanita untuk melakukan ritual berikutnya yaitu mappasikarawa. Namun sebelum memasuki kamar wanita, pihak 
laki-laki dihadang di depan pintu kamar untuk dimintai seserahan oleh orang-orang yang dipercayai, atau orang-orang yang memiliki kekuasaan dan dihormati oleh keluarga si wanita. Di depan pintu akan terjadi tarik-menarik atau negosiasi antara mempelai laki-laki dan penjaga pintu. Jika penjaga pintu merasa belum puas dengan seserahan yang dipersembahkan si pria, maka penjaga pintu akan meminta seserahnnya di tambahkan. Adapun seserahannya berupa uang logam, gula-gula dan semacamnya. Pintu akan dibuka setelah seserahan disetujui oleh keluarga mempelai wanita.

Setelah pintu dibuka mempelai laki-laki dipersilahkan memasuki kamar dan didudukkan di sebelah istrinya untuk mengikuti prosesi mappasikarawa. Prosesi Mappasikarawa ini dituntun oleh orang yang disebut pappasikarawa. Pappasikarawa kemudian mengarahkan tangan suami kebagian tubuh istrinya yang baik untuk disentuh. Dalam tradisi mappasikarawa, bagian tubuh wanita yang disentuh tidaklah sembarangan. pappasikarawa akan mengarahkan tangan sang suami ke bagian tubuh yang dianggap mampu membawa berkah terhadap kehidupan kedua mempelai dalam mengarungi bahtera rumah tangga. Adapun bagian-bagian yang dapat disentuh oleh sang suami ialah jempol/ibu jari, jabat tangan, pangkal, lengan, hidung, leher, dada, telinga, perut, dan ubun-ubun.

Harapan yang terdapat dalam tradisi mappasikarawa yaitu jempol/ibu jari adalah suami istri tidak egois dan bekerjasama dalam membangun rumah tangga yang berkah. Jabat tangan adalah saling memaafkan dan mempererat hubungan suami istri. Pangkal lengan adalah dengan bekerja keras kelak diharpkan murah rezeki dan tidak merasakan kesulitan rezeki. Hidung adalah dapat mencium aroma masakan istri. Dada (di atas buah dada) adalah dapat mendatangkan rezeki yang melimpah seperti tingginya gunung. Telinga adalah agar istri patuh dan senantiasa mendengar ajaran suaminya. Perut adalah agar tidak mengalami kelaparan dengan anggapan bahwa perut selalu diisi. Mencium ubun-ubun adalah saling sayang sebagai suami istri. (Syaiful Arifin, dkk: 2018)

Bagi masyarakat bugis, tradisi mappasikarawa diharapkan dapat mendatangkan berkah bagi kedua pasangan. Maka dari itu prosesi mappasikarawa dipercayai sebagai keberhasilan kedua 
pengantin untuk membina mahligai rumah tangga. Untuk melakukan ritual mappasikarawa, maka prosesnya dituntun oleh orang yang dinamakan dengan pappasikarawa. Memilih pappasikarawa tidaklah sembarangan, dikarenakan masyarakat bugis meyakini pappasikarawa dapat menentukan hidup dan matinya serta keberlanjutan kehidupan rumah tangga si laki-laki dan istrinya kelak. Maka dari itu kedua pihak mempelai harus jeli memilih orang-orang pintar untuk melakukan prosesi mappasikarawa.

Benarkah mappasikarawa dapat dijadikan tolak ukur keberhasilan hubungan berumah tangga kedepannya?

Keberhasilan perkawinan tercermin pada besar kecilnya hubungan interpersonal dan pola perilaku. Sampai sejauh tertentu kriteria ini bervariasi bagi orang yang berbeda dan bagi perkawinan pada usia yang berbeda. Unsur-unsur ini dapat digunakan untuk menilai tingkat penyesuaian perkawinan seseorang. Kriteria tersebut antar lain: (a) kebahagian suami istri; (b) kemampuan untuk memperoleh kepuasan dari perbedaan pendapat; (c) penyesuaian yang baik masalah keuangan; (d) penyesuaian yang baik dari keluarga pasangan. (N. Kardinah: 2009)

Tahun-tahun pertama perkawinan merupakana masa rawan, bahkan dapat disebut sebagai era kritis karena pengalaman bersama belum banyak. Menurut Clinebell (2005), periode awal perkawinan merupakan masa penyesuaian diri, dan krisis muncul saat pertama kali memasuki jenjang pernikahan. Pasangan suami istri harus banyak belajar tentang pasangan masing-masing dan diri sendiri yang mulai dihadapkan dengan berbagai masalah. Dua kepribadian (suami maupun istri) saling menempa untuk dapat sesuai satu sama lain, dapat memberi dan menerima. (N. Kardinah: 2009)

Mappasikarawa diharapkan dapat memberi kebaikan terhadap hubungan kedua pengantin. Namun tidak ada hubungannya dengan keberhasilan mahligai rumah tangga yang telah dibangun oleh kedua mempelai. Karena mappasikarawa hanya bagian dari prosesi pernikahan suku bugis, yang tidak dapat ditinggalkan dan sudah diwariskan secara turun-temurun. Uraian di atas menunjukkan bahwa keberhasilan sebuah hubungan pernikahan dapat diciptakan oleh kedua pasangan melalui hubungan interpersonal, banyak belajar 
tentang pola perilaku pasangan, serta dapat memberi dan menerima baik buruknya pasangan.

Islam merupakan agama yang lengkap dengan segalanya yang telah diatur dan memiliki ketentuan. Termasuk ketentuan pernikahan yang telah disunnahkan Nabi Muhammad Saw. Ketentuan atau aturan-aturan pernikahan yang sudah ditetapkan dalam Islam sangatlah lengkap beserta tata caranya. Namun setiap masyarakat memiliki tradisi pernikahan, yang kadang kala dicampuradukkan dengan syariat Islam. tak jarang ada sebagian masyarakat yang lebih memilih mengedepankan tradisi dibandingkan ketetapan Allah Swt, dan jauh dari kesan Islami.

Adat atau urf dipahami sebagai sesuatu kebiasaan yang telah berlaku secara umum di tengah-tengah masyarakat. Di seluruh penjuru negeri atau pada suatu masyarakat tertentu yang berlangsung sejak lama (Fadal, 2008: 69).

Dari definisi tersebut, para ulama menetapkan bahwa sebuah tradisi yang bisa dijadikan sebagai sebuah pedoman hukum adalah: Tradisi yang telah berjalan sejak lama yang dikenal oleh masyarakat umum. Diterima oleh akal sehat sebagai sebuah tradisi yang baik. Tidak bertentangan dengan nash Alquran dan hadis Nabi Saw.

Menurut ulama, adat atau tradisi dapat dijadikan sebagai dasar untuk menetapkan hukum syara' apabila tradisi tersebut telah berlaku secara umum dimasyarakat tertentu. Sebaliknya jika tradisi tidak berlaku secara umum, maka ia tidak dapat dijadikan sebagai pedoman dalam menetukan boleh atau tidaknya tradisi tersebut dilakukan (M. Najmuddin, dkk)

Tradisi mappasikarawa yang kerap dipercayai sebagian masyarakat bugis, yaitu sebagai prosesi yang dapat mendatangkan berkah bagi pasangan yang sudah sah sebagai suami istri, juga meyakini bahwa orang yang melakukan ritual mappasikarawa tersebut adalah orang pilihan yang diakui mampu menjadikan mahligai rumah tangga kedua pasangan berjalan lancar ataupun gagal, tergantung dari siapa pappasikarawa yang ditunjuk. Jika niat pappasikarawa itu baik maka hubungan pernikahan tersebut akan langgeng. Namun bila niat pappasikarawa buruk maka hubungan pernikahan bisa saja berantakan. 
Menurut salah satu masyarakat suku Bugis. Menceritakan bagaimana pandangannya terhadap tradisi mappasikarawa, "Mappasikarawa Supaya sipoji'i boting e sibawa lakenna. Ako meja' pappasikarawa na, de nule si pojie.e. Ako makanja pappasikarawa na nulle' sipoji botting e." (Tradisi mappasikarawa agar pengantin menyukai suaminya. Jika pappasikarawa buruk, pengantin tidak bisa saling menyukai. Jika pappasikarawa baik mempelai bisa saja saling menyukai).

Dalam sudut pandang Islam pemikiran semacam ini dianggap tidak sesuai ajaran Islam. Dimana yang dimaksud dengan musyrik disini ialah perbuatan menyekutukan Allah dengan apapun. Seperti yang disinggung pada poin nomor tiga, bahwa sebuah tradisi yang bisa dijadikan sebagai sebuah pedoman hukum adalah tidak bertentangan dengan nash Alquran dan hadis Nabi SAW.

Namun tradisi mappasikarawa tersebut telah bertentangan dengan nash Alquran dan hadis. Layaknya kepercayaan masyarakat Bugis terhadap tradisi mappasikarawa. Dimana masyarakat menaruh kepercayaannya kepada pappasikarawa bahwa ia mampu mendatangkan kebaikan maupun keburukan terhadap hubungan kedua pengantin. "Allah Tabaraka wa Ta'ala berfirman,'Aku tidaklah butuh adanya tandingan-tandingan. Barangsiapa yang mengerjakan suatu amal dalam keadaan menyekutukan Aku dengan selain Aku, maka Aku akan meninggalkan dia dan perbuatan syiriknya itu. "' (HR. Muslim)

Karena tradisi ini telah berjalan lama dan diterima oleh akal sehat. maka tidak ada yang salah dari tradisi mappasikarawa. Disebabkan tradisi mappasikarawa yang artinya sentuhan pertama kedua mempelai, setelah menjalankan salah satu syariat Islam yaitu ijab qabul, dimana dalam Islam pasangan yang sudah sah sebagai suami istri tidak haram lagi untuk bersentuhan.

Hanya saja sebagian masyarakat bugis meyakini bahwa tradisi mappasikarawa-lah yang membuat hubungan pernikahan berhasil ataupun gagal. serta melupakan bahwa banyak faktor-faktor yang dapat membuat hubungan tersebut berjalan lancar ataupun terhenti. Pemikiran semacam inilah yang keliru, dan keluar dari ajaran-ajaran Islam. Hal tersebut dapat terjadi disebabkan terpengaruh oleh kepercayaan terhadap takhayul yang berlebihan, serta minimnya 
pengetahuan tentang syariat, sehingga melupakan kuasa Allah Ta'ala.

Berdasarkan uraian di atas maka diperoleh kesimpulan sebagai berikut: mappasikarawa merupakan tradisi pernikahan suku Bugis. Mitosnya tradisi ini dipercayai sebagai tolak ukur keberhasilan ataupun kegagalan dalam berumahtangga. Masyarakat Bugis menaruh kepercayaan terhadap orang yang melakukan tradisi mappasikarawa.

Mappasikarawa selain menjadi prosesi adat, juga merupakan momen sentuhan pertama yang dilakukan kedua pengantin dengan perantara pappasikarawa. Untuk melakukan sentuhan pertama tersebut tidaklah sembarangan. Bagian-bagian tubuh yang disentuh memiliki maknanya tersendiri: (1) jempol/ibu jari adalah suami istri tidak egois dan bekerjasama dalam membangun rumah tangga yang berkah; (2) jabat tangan adalah saling memaafkan dan mempererat hubungan suami istri; (3) pangkal lengan adalah dengan bekerja keras kelak diharapkan murah rezeki dan tidak merasakan kesulitan rezeki; (4) hidung adalah dapat mencium aroma masakan istri; (5) dada (di atas buah dada) adalah dapat mendatangkan rezeki yang melimpah seperti tingginya gunung; (6) telinga adalah agar istri patuh dan senantiasa mendengar ajaran suaminya; (7) perut adalah agar tidak mengalami kelaparan dengan anggapan bahwa perut selalu diisi; (8) mencium ubun-ubun adalah saling sayang sebagai suami istri.

Mappasikarawa yang dipercaya sebagian masyarakat bugis, sebagai keberhasilan kelanjutan hubungan kedua mempelai, tidak lepas dari sudut pandang agama. Islam yang merupakan agama dalil, yang mengatur segala hal dari yang kecil sampai besar, tentu tidak luput aturannya terhadap pernikahan. Pernikahan dalam Islam dikemas sederhana dan mudah dijalankan. Islam tidak melarang pernikahan yang tercampur-aduk dengan prosesi adat. Hanya saja jika kebudayaan jauh dari ajaran atau aturan agama, maka hal tersebut berujung kepada kebencian Allah SWT terhadap umat, dan bertentangan dari hukum syariat yang telah ditetapkan.

Bukan tradisi mappasikarawa yang menjadikan hubungan rumahtangga langgeng, melainkan ridho dari Allah dan cara kedua 
pengantin membina rumah tangganya selama pernikahan. Hal ini tidak terlepas dari komunikasi dan penyesuaian diri kedua pasangan selama menjalankan pernikahan. 


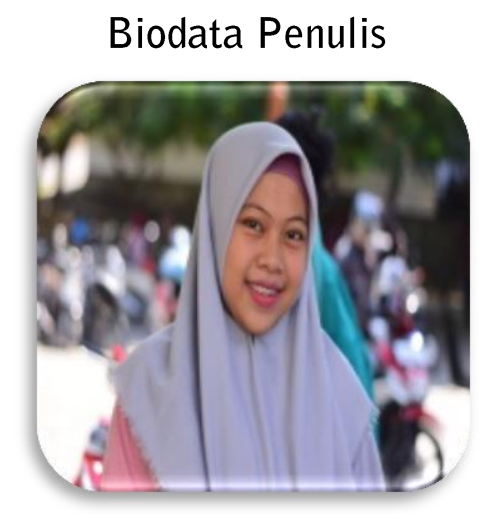

Wanda Putri Nanda, Lahir di Dusun Karaballo, Pinrang, Sulawesi Selatan. Pada 18 Oktober 1999. Ia adalah mahasiswa dari Institut Agama Islam Negeri (IAIN) Parepare, dengan program studi (prodi) Jurnalistik Islam. Lahir dari orang tua bernama Azis (ayah) dan Rusna (ibu), sebagai anak ke-empat dari lima bersaudara. Penulis menempuh pendidikan di Kalimantan Selatan dimulai dari SDN Sei-Taib Desa Sungai Taib (lulus tahun 2012), melanjutkan ke SMPN 6 Kotabaru Desa Mandin (lulus tahun 2015), dan SMAN 1 Kotabaru Desa Sigam (lulus tahun 2018), hingga akhirnya bisa menempuh masa kuliah di Fakultas Ushuluddin, Adab dan Dakwah IAIN Parepare, Sulawesi Selatan. Karena keaktifannya semasa sekolah ia menjadi Wakil Ketua Osis SMPN 6 Kotabaru. Ia pernah mengikuti Festival Lomba Seni Siswa Nasional (FLS2N) pada tingkat Kabupaten. Ia aktif mengikuti lomba Tari Rudat yang diadakan setahun sekali. Ia juga pernah menjadi anggota organisasi kesehatan Palang Merah Indonesia (PMI). Pramuka dan Seni Tari adalah ekstrakulikuler yang pernah diikutinya.

\section{Motto "Kritik Membinasakan adalah Motivasi Kebangkitan"}




\section{Tradisi Barazanji pada masyarakat Parepare di Kecematan Bacukiki Kelurahan Lompoe}

Seiring perkembangan zaman, dalam masyarakat yang ingin serba praktis dan singkat, banyak tradisi masyarakat yang tidak bertahan sampai sekarang. Meskipun demikian, masih banyak juga tradisi yang masih bertahan sampai sekarang, salah satunya adalah tradisi pembacaan kitab Barzanji. Pembacaan kitab ini tidak hanya dilakukan di wilayah Indonesia yang mayoritas penduduknya memeluk agama Islam, tapi tradisi ini juga dilakukan oleh kebanyakan umat Islam yang tersebar di seluruh penjuru dunia untuk memperingati hari kelahiran Nabi Muhammad saw.

Tradisi pembacaan kitab Barzanji sebenarnya bukanlah hal yang wajib dilakukan oleh umat Islam atau pun sebuah ritual yang harus dilakukan di setiap hari kelahiran Nabi. Barzanji hanya dilakukan untuk mengambil hikmah dan meningkatkan kecintaan umat terhadap nabinya, menjadikannya suri tauladan dalam kehidupan sehari-hari.

Tradisi Barzanji di Indonesia sudah merupakan hal yang lazim dilakukan oleh masyarakatnya. Pembacaan kitab Barzanji pun tidak hanya dilakukan pada saat perayaan hari kelahiran Nabi saja, tetapi juga dilakukan ketika merayakan kelahiran anak, khitanan, perkawinan, dan sebagainya. Tujuannya memohon berkah kepada Allah agar apa yang hajatkan terkabul.

Walaupun Barzanji sudah menjadi tradisi umum yang dilakukan oleh masyarakat Indonesia, bukan berarti di setiap daerah memahami tradisi Barzanji sama dengan daerah lainnya. Seperti halnya masyarakat Bugis kota Parepare tepatnya di kecematan Bacukiki, mereka memahami Barzanji sebagai sesuatu yang sakral dan "wajib" dilakukan ketika melaksanakan suatu upacara adat. Tanpa Barzanji suatu upacara adat dikatakan belum sempurna.

Bagi mereka, Barzanji merupakan penyempurna dari upacara adat yang mereka lakukan. Sebagian besar masyarakat kec. bacukiki juga percaya, bahwa orang yang melakukan hajatan tanpa melaksanakan Barzanji akan mendapat musibah. Dari penjelasan tersebut penulis berkesimpulan, bahwa kesakralan dari Barzanji 
bukan terletak pada buku Barzanjinya, siapa yang membacanya atau siapa yang mengadakannya, tapi letak kesakralannya pada tradisi atau acara Barzanji itu sendiri.

Kedatangan Islam di tanah Bugis tidak mengubah secara keseluruhan tradisi atau adat istiadat mereka, di sini terjadi percampuran antara kepercayaan masyarakat pribumi sebelum datangnya Islam dan setelah diterimanya ajaran Islam. Hal tersebut bisa kita saksikan pada acara syukuran kelahiran anak di Kecematan Bacukiki.

Berdasarkan hasil wawancara dengan salah satu warga di Kecematan Bacukiki, menurutnya tradisi barazanji dilakukan pada saat ini memang masih tetap ada. Tradisi barazanji paling sering dilakukan pada saat acara syukuran kelahiran anak,syukuran rumah aru atau kendaraan baru (Wawancara Informan)

Nabi Muhammad adalah Nabi pembawa risalah Islam, Rasul terakhir penutup rangkaian Nabi-Nabi dan Rasul-Rasul Allah di muka bumi. Nabi Muhammad berhasil membawa manusia beralih dari masa kegelapan menuju kehidupan berdasarkan tauhid. Beliau adalah makhluk paling sempurna dan paling dihormati yang dikirim Allah sebagai pemberi syafaat bagi seluruh umat.

Kelahiran Nabi Muhammad merupakan suatu peristiwa sejarah dalam kehidupan manusia. Kelahiran beliau bukan sekedar hanya kelahiran pribadi sebagai manusia utama, tetapi merangkum seluruh segi kehidupan umat manusia dalam menghadapi perkembangan sejarah di masa depan. Sebagai bentuk perwujudan cinta dan rasa hormat kepada Nabi Muhammad diwujudkan dengan membaca shalawat dan salam kepada-Nya, karena Allah dan Malaikat-Nya pun menyatakan penghormatannya dalam surat alAhzāb.

Dalam kitab al-Barzanji dilukiskan riwayat hidup Nabi Muhammad dengan bahasa yang indah, berbentuk puisi serta prosa (nasr) dan qasidah yang sangat menarik, perhatian orang yang membaca atau mendengarkannya, apalagi yang memahami arti dan maksudnya. Namun harus kita akui, bahwa cara pembacaan kitab tersebut pada umumnya tidak disertai penjelasan dan maknanya dalam bahasa Indonesia atau ke dalam bahasa daerah. Titik berat 
pembacaannya kebanyakan hanya ditekankan pada makhraj, irama dan lagu, sehingga para peserta yang pada umumnya tidak menguasai bahasa Arab, tidak memahami makna yang dibaca dan didengarkan. Kenyataan itu memang merupakan kekurangan yang patut menjadi perhatian kita, sekalipun kekurangan itu tidak mengurangi nilai kekhusyu'an peringatan maulid.

Sekalipun para peserta tidak memahami apa yang dibacakan dan didengar, namun dengan sepenuh hati dan sepenuh perasaan mereka mengikutinya dengan khidmat dan dengan khusyü' mengagungkan kebesaran Allah serta mengagungkan kemuliaan Rasul-Nya. Sudah pasti disertai harapan memperoleh keridhoan Allah dan kebajikan yang sebesarbesarnya. Barzanji ialah suatu doa-doa, puji-pujian dan penceritaan riwayat Nabi Muhammad saw yang dilafalkan dengan suatu irama atau nada yang biasa dilantunkan ketika kelahiran, khitanan, pernikahan dan maulid Nabi Muhammad saw. Isi Berzanji bertutur tentang Muhammad, yang disebutkan berturut-turut yaitu silsilah keturunannya, masa kanak-kanak, remaja, pemuda, hingga diangkat menjadi Rasul. Di dalamnya juga mengisahkan sifat-sifat mulia yang dimiliki Nabi Muhammad, serta berbagai peristiwa untuk dijadikan teladan umat manusia.

Nama Berzanji diambil dari nama pengarangnya yaitu Syekh Ja'far al-Barzanji bin Hasan bin Abdul Karim. Ia lahir di Madinah tahun 1690 dan meninggal tahun 1766. Barzanji berasal dari nama sebuah tempat di Kurdistan, Barzinj. Karya tersebut sebenarnya berjudul 'Iqd al-Jawahir (Bahasa Arab, artinya kalung permata) yang disusun untuk meningkatkan kecintaan kepada Nabi Muhammad saw, meskipun kemudian lebih terkenal dengan nama penulisnya.

Tradisi atau kebiasaan, dalam pengertian yang paling sederhana adalah sesuatu yang telah dilakukan untuk sejak lama dan menjadi bagian dari kehidupan suatu kelompok masyarakat biasanya dari suatu negara, kebudayaan, waktu, atau agama yang sama. Hal yang paling mendasar dari tradisi adalah adanya informasi yang diteruskan dari generasi ke generasi baik tertulis maupun (sering kali) lisan, karena tanpa adanya ini, suatu tradisi dapat punah (http://repositori.uin-alauddin.ac.id)

Acara pembacaan barsanji dimulai disebuah rumah warga. acara dimulai, pembacaan Ada yang pergi panggil imam dan para 
tokoh-tokoh agama, dan santri-santri. Jadi ungkapan informan di atas sebagian keluarga yang datang membantu untuk mempersiapkan apa-apa yang dibutuhkan, bahkan ada juga yang pergi buat urus memanggil imam dan tokoh agama dan anak pesantren. Lanjutnya ungkapan salah satu informan ini, "jadi,iyyanaro tujuanna engka manengi" maddeppungen keluarga iro mabelae,nappaki sirituntu manengi." Terjemahan: Jadi, maksudnya supaya datang semua berkumpul keluarga yang jauh, kemudian disitumi saling ketemu. Jadi dapat disimpulkan bahwa, pelaksanaan acara-acara pembacaan barzanji dimanfaatkan sebagai tempat pertemuan antara keluarga yang jauh supaya bisa kembali saling berkumpul.

Jadi ditarik kesimpulan bahwa acara-acara pembacaan barzanji digunakan sebagai tempat berkumpulnya para keluarga yang jauh-jauh dan sebagai juga mempererat hubungan kembali, setiap ada acara-acara pasti ramai berdatangan untuk membantu proses-proses apa yang dibutuhkan. Setiap ada yang melakukan acara pasti warga berdatangan lagi untuk saling membantu.

Barzanji diawali dengan pembacaan Ummul Quran oleh imam. Selanjutnya pembacaan barzanji dimulai oleh imam dan dilanjutkan oleh pembaca berikutnya, yaitu para undangan lainnya sampai bait terakhir. Barzanji yang dibaca adalah barzanji Natsar. Setelah pembacan selesai baru dilanjutkan lagi dengan doa penutup yang dipimpin oleh sang imam. Setelah pembacaan doa penutup dilakukan, dilanjutkan dengan menghidangkan-hidangan untuk dinikmati oleh seluruh undangan dan hadirin yang hadir. Seperti ungkapan informan ini dalam wawancara "pada engka manenngi" keluarga-keluarga jokka bantuki mappatala" iro ifaka"e ko barasanjieengka to" jokka molliwi puang imam,tokoh-tokoh agama dan anak-anak santri" $e^{\prime \prime}$ Terjemahan: Para keluarga datang membantu untuk mempersiapkan bahan-bahan yang akan dipakai selama kegiatan pa"barzanji.

Tahap persiapan adalah tahap untuk merumuskan dan mengumpulkan alat serta bahan yang akan digunakan dalam pelaksanaan upacara barazanji. Pelaratan saat pembacaan Barazanji. Keluarga yang melaksanakan pembacaan barazanji terlebih dahulu 
membuat hidangan yang akan diletakkan depan imam, yang biasa disebut dalam bahasa bugis "nanre barazanji"(hidangan barazanji).

Hidangan itu berupa 7 buah talam yang berisi 7 anak piring, yaitu: 1(satu) piring ikan goreng. 1(satu) piiring ayam goreng, 1 (satu) piring kari ayam, 1(satu) piring kari sapi/kambing, 1(satu) piring udang goreng, 1(satu) piring telur, 1(satu) piting tempa-tempa dan disertakan nasi yang sesuai dengan kondisi talam, yang berisikan: Sokko' (songkolo) warna kuning dan pisang, Kue-kue (Kamaruddin Skripsi)

Anggota masyarakat yang mendapat limpahan rezeki dan berhasil membeli mobil (kendaraan baru), akan mengadakan upacara barzanji sebagai tanda kesyukuran mereka atas kepemilikan mobil baru itu. Upacara ini biasanya diadakan di atas mobil atau di rumah yang dilengkapi sajian bermacam-macam kue seperti jompo-jompo, onde-onde, dan bella lawo. Sebagian anggota masyarakat pantang untuk menyembelih hewan seperti kerbau, sapi, kambing, atau ayam dalam upacara tersebut. Apabila pembacaan barzanji itu sampai pada 'assaraka badru' maka imam sebagai pemimpin upacara berdiri mengambil air passili yang telah disediakan lalu memercikkan ke bagian-bagian tertentu pada mobil itu seperti ban, stir, tempat duduk, dan bagian depan atau tanduknya. Upacara barzanji ini biasanya mereka percaya bahwa apabila mereka lakukan, supaya diberika keselamatan dan dipakai juga buat berbisnis.

Seperti Informan satu ini mengungkapkan alasannya ketika melaksanakan upacara barzanji pada kendaraan barunya (mobil baru/oto"barunna): iyya ro tujuanna ku melliki oto baru, mello salamatta". Tradisi metto ro ritujunna agama selleng"e. nollini imam,e baca"e beppa pitung rupu. Beppa ye denapakai telur, kaya jompo2 sanggara. Karena tradisi memang saya kalau beli mobil, selalu memang saya begitu. melli oto ibaca doangen salamaki, buat diapakai dengan baik buat diapakai usaha dengan baik. Terjemahan: tujuaanya barazanji pada saat ada mobil baru, yaitu supaya dipakai selamat. Dipanggil imam buat dibacakan kue tujuh macam. Kue yang tidak pakai telur, kaya jompo-jompo, sanggara. Karena sudah menjadi tradisi bagi saya setiap beli mobil baru. Selalu memang saya begitu. Kalau beli mobil baru didoakan agar dipakai selamat, buat dipakai dengan baik dan dipakai usaha dengan baik. 
Jadi disimpulkan maksud dan tujuan informan ini melaksanakan acara barzanji pada mobil barunya ialah, hanya untuk dipakai selamat dan dipakai dengan baik untuk usaha. Selanjutnya ungkapan informan ini pada saat melaksanakan barzanji: "menre"ni ko otoe napamerrunni mabarasanji"ni, jadi marukka oninna masina"e na"barasanji toni. Degage lo"makkampareng nasaba malleria ade"." Terjemahan: kalau misalnya barazanji pada saat ada mobil baru. Kita naik di atasnya atau masuk di dalamnya mobil sambil melakukan barazanji, bunyi kendaraan juga menyala tetapi tetap melaksanakan barzanji. Tidak ada yang berani menegur, karena sebagai adat. Jadi disimpulkan bahwa, upacara pada saat mobil baru adalah masyarakat menganggap supaya diberikan keselamatan dan diberikan rejeki dan supaya dipakai selamat ini kendaraan dan sudah menjadi tradisi bagi warga setempat setiap yang memiliki kendaraan baru pasti melaksanakan barzanji di atas mobilnya. (http://repository.stainparepare.ac.id)

Adapun Nilai yang terkandung dalam kegiatan barasanji ini adalah sebagai berikut.

1. Nilai Religius

Pembacaan kita Barzanji merupakan bentuk bukti kecintaan penganut agama Islam terhadap Nabi Muhammad SAW. Syair dan hakikat yang tertulis dalam kitab tersebut memaparkan nilai-nilai yang baik yang dapat meningkatkan kadar religiusitas seseorang. Selain itu, masyarakat juga dapat mengambil hikmah dari kehidupan Nabi Muhammad SAW dari kitab tersebut.

2. Nilai Sosial

Dengan tradisi barzanji yang digelar, dapat mempererat tali silaturrahmi Tradisi Barzanji yang digelar pada perayaan hari besar seperti Maulid Nabi dan berbagai upacara lainnya di masyarakat, seperti perkawinan, kelahiran anak, khitanan, dan lain-lain membuka ruang besar bagi masyarakat untuk bersosialisasi antara satu dengan lainnya. Karena, dengan kegiatan semacam inilah, mereka yang jarang bertemu akan bertemu dan mempererat tali persaudaraan dan ikatan sosial di antara mereka dalam masyarakat. 


\section{Nilai Budaya}

Syair-syair yang terangkum dalam kitab Barzanji, meskipun menceritakan kehidupan Nabi Muhammad SAW, merupakan karya yang bernilai sastra tinggi. Sebgaimana yang kita ketahui, bangsa Arab mempunyai tradisi penulisan sastra yang kuat. Hal ini sejalan dengan budaya Melayu yang juga mempunyai tradisi sastra yang tidak bisa dikatakan bermutu rendah. Perpaduan antara kedua budaya inilah yang akan menghasilakn bentuk budaya baru. Perpaduan yang juga memperkaya kebudayaan Indonesia.

Tradisi ini merupakan bagian dari kebudayaan yang seharusnya dapat dipelihara dan dilestarikan, karena kebesaran suatu bangsa dapat dilihat dari suatu budaya. Sama halnya dengan keberhasilan suatu Agama (ajaran) dapat dilihat dari penganutnya dari kebudayaan setempat. Oleh karena itu, tradisi tidak perlu dihilangkan, karena tradisi akan mengalami perubahan secara sendirinya mengikuti perkembangan zaman.

Dengan dilestarikannya tradisi, bukan hanya memperkaya kebudayaan suatu bangsa, tetapi meningkatkan perekonomian bagi suatu bangsa. Mengenai tradisi yang ada di Kecematan Bacukiki, perlu adanya pembelajaran tentang tradisi pembacaan barazanji bagi generasi muda setempat. Agar tradisi tersebut tetap bisa terpelihara dan tidak hilang begitu saja. Karena saat ini yang melakukan tradisi barazanji hanya bagi kalangan orang tua saja, para remaja kurang berpartisipasi dalam pelaksanaan barazanji.

Pada saat ini tradisi dan budaya mulai berkurang dilakukan sebagian orang, maka dari itu kita sebagai masyarakat yang mempunyai kekayaan tradisi dan budaya seharusnya sadar betul untuk ikut serta melestarikan tradisi Barazanji. Supaya anak cucu kita kedepannya paham bahwa Indonesia memiliki kekayaan tradisi dan budaya. Serta memperhatikan potensi tersebut.

Cara melestarikan dengan melakukan sesuai aturan dan tidak mengurangi atau menambah nilai dari tradisi tersebut. Sebagai contoh Barazanji yang memiliki manfaat sebagai shalawat terhadap nabi besar Muhammad SAW. Cara lainnya adalah belajar dari orang yang tahu betul tentang adat tradisi tersebut dan mempelajarinya. 
Walaupun Barzanji sudah menjadi tradisi umum yang dilakukan oleh masyarakat. bukan berarti di setiap daerah memahami tradisi Barzanji sama dengan daerah lainnya. Seperti halnya masyarakat Bugis, mereka memahami Barzanji sebagai sesuatu yang sakral dan "wajib" dilakukan ketika melaksanakan suatu upacara adat. Tanpa Barzanji suatu upacara adat dikatakan belum sempurna. Barzanji merupakan penyempurna dari upacara adat yang mereka lakukan. Sebagian besar masyarakat juga percaya, bahwa orang yang melakukan hajatan tanpa melaksanakan Barzanji akan mendapat musibah. Dari penjelasan tersebut peneliti berkesimpulan, bahwa kesakralan dari Barzanji bukan terletak pada buku Barzanjinya, siapa yang membacanya atau siapa yang mengadakannya, tapi letak kesakralannya pada tradisi atau acara Barzanji itu sendiri. 


\section{Biodata Penulis}

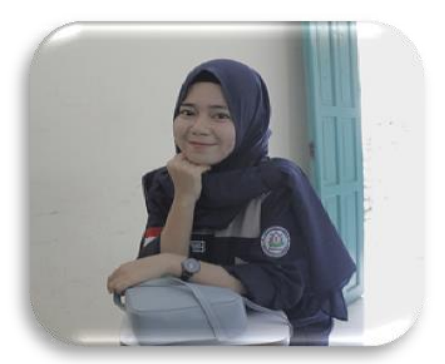

Sitti Badriah, tempat tanggal lahir Parepare, 29 Agustus 2000. Nama Orang Tua : Husni Thamrin (Ayah) Rahmawati (Ibu) Alamat BTN Cadika Permai, kecematan Bacukiki, kelurahan Lompoe, kota Parepare.

Motto: "Jangan mudah menyerah, meskipun jatuh berkalikali" (;) 


\section{Sigajang Laleng Lipa}

Keragaman budaya sesungguhnya terletak pada budayabudaya lokal, salah satu tradisi upacara adat yang tergolong hampir hilang akibat pengaruh globalisasi yaitu tradisi upacara adat sigajang laleng lipa di Sulawesi-Selatan. Sejarah Sigajang Laleng Lipa.

Sigajang Laleng Lipa adalah salah satu ritual penting pada masyarakat bugis yang keberadaannya hampir hilang ditelan zaman. Ritual ini dilakukan dengan menyatukan dua pria di dalam sebuah sarung. Kedua pria nantinya akan saling bertarung dan adu kekuatan hingga keduanya sama-sama mati atau sama-sama hidup, atau salah satunya mati. Jarang dalam ritual ini pihak yang mati atau hidup sendirian.

Ritual Sigajang Laleng Lipa mulai dilakukan pada masa Kerajaan Bugis ratusan tahun lalu. Di masa lalu, jika ada dua keluarga yang berseteru, penyelesaian terakhirnya adalah dengan adu kekuatan ini. Kalau ada keluarga yang harga dirinya diinjak, pertarungan ini akan dilangsungkan agar segala permasalahan segera diselesaikan dan perselisihan tidak terus terjadi.

Menurut Andi Rahmat sigajang laleng lipa ini adalah sebuah tradisi berdarah yang dimiliki masyarakat Bugis untuk menyelesaikan sebuah masalah. Tradisi ini sendiri artinya saling tikam menggunakan badik dalam satu sarung, dan sebelum Itu di lakukan Kesepakatan dua pihak yang ingin bertarung di dalam sarung apabila salah satunya meninggal maka pihak satunya tidak dikenakan sanksi apapun.

Sigajang Laleng Lipa sendiri dianggap sebagai cara terakhir apabila tidak mencapai kata damai dalam sebuah musyawarah untuk menyelesaikan masalah, agar masalah selesai diselesaikanlah dengan cara sigajang laleng lipa. Konon, tradisi ini berasal dari sifat masyarakat bugis yang menjunjung tinggi rasa malu, atau yang dalam bahasa bugisnya disebut siri.

Siri ini sangat mempengaruhi kehidupan masyarakat Bugis. Bahkan ada pepatah yang mengatakan, hanya orang yang punya siri yang dianggap sebagai manusia, dan hampir semua orang bugis 
mempunyai perinsip narekko siri kuh mo'lejja-lejja copponna mih Kawalie ma'bicara, yang artinya jika malu saya kamu injak-injak maka ujungnya Badik yang bertindak. Sigajang Laleng Lipa sendiri telah ada sejak masa kerajaan bertahun-tahun silam dan ritual ini dilakukan oleh dua orang yang berduel dalam satu sarung, keduanya menggunakan badik. Dalam tradisi tersebut, tak tanggung tanggung, nyawa taruhannya.

Terkadang pulah dipentaskan kembali dalam sebuah panggung untuk menjaga kelestarian warisan budaya. Pementasan ini dimulai dengan pementasan tari, dan ritual bakar para penari menggunakan obor. Namun, para penari tetap tersenyum dan tidak tersengat kepanasan, setelah itu barulah kedua pementas beradu dalam sarung untuk melakukan gajang laleng lipa. Menurut kepercayaan, ritual ini memiliki makna tersendiri, dimana sarung diartikan sebagai simbol persatuan dan kebersamaan masyarakat Bugis.

Berada dalam sarung berarti menunjukkan, diri mereka ada dalam satu tempat dan ikatan yang menyatukan, dalam kata lain ikatan kebersamaan antar manusia. Meski terkesan brutal dan mengerikan, ritual ini merupakan tradisi dan ciri khas masyarakat Bugis. Ketika perselisihan tak dapat dihindari karena sebuah perselisihan dan menjunjung harga diri yang harus ditegakkan. Di saat itulah nyawa tak ada artinya, dan konflik berdarah harus dilakukan dalam ritual bernama gajang laleng lipa, ini sangat memerlukan keberanian tersendiri. Hal ini tak lain dan tak bukan adalah untuk menjunjung kemulian dan harga diri manusia.

Baginilah Masyarakat bugis yang menyelesaikan masalahnya dengan cara yang terbilang sangatlah sadis, tetapi masyarakat bugis mempunyai jiwa tali persaudaaran yang sangat baik mereka rela berdarah demi orang yang mereka anggap saudara, masyarakat bugis juga terkenal sangat pemberani seluruh pulau yang ada di Indonesia bahkan sampai di negeri tentangga Pun malaysia dan singapura orang bugis terkenal pemberani dan disegani.

Maka dari itu kita mengambil hal positifnya saja dari pembelajaran di atas di samping itu kita tidak boleh melupakan adat dan budaya kita dimana kita berada, kita tidak perlu menyelesaikan masalah Seperti orang bugis, yang menyelesaikan masalahnya 
dengan cara sigajang laleng lipa, Kita cukup mempertunjukkan memahami kebudayaan kita dan memperkenalkannya kepada orangorang, agar orang-orang bisa belajar dari budaya kita. Agar budaya kita tetap terjaga dan tidak direbut oleh orang lain, karena jika bukan kita yang mempertahanan warisan budaya maka siapa lagi, betapa bangganya kita melihat anak dan cucu kita kelak, akan adat dan budaya kita, maka dari sekarang kita harus belajar menghargai budaya kita jangan sampai kita lahir di tanah bugis tetapi orang lain lebih mengenal budaya bugis ketimbang kita yang orang bugis asli. 


\section{Biodata Penulis}

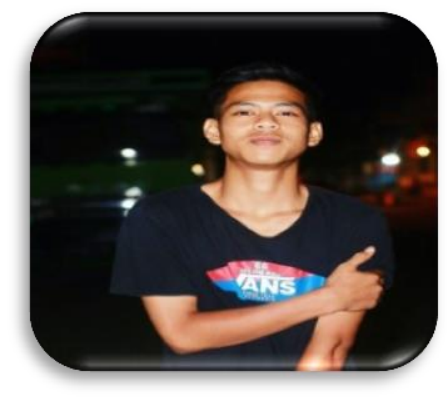

Andi Raul Sanapati lahir di Parepare, tepat pada tanggal 11, januari, 2000 Pada tahun 2005, saya mulai memasuki bangku sekolah dasar. Saat itu saya bersekolah di SD negri 47 Parepare, selama 6 tahun lamanya. Setelah itu saya melanjutkan ke jenjang SMP. Negeri 2 parepare, selama 3 tahun lamanya. Pada tahun ajaran 2013, saya lulus dari SMP tersebut. Setelah saya lulus dari SMP saya melanjutkan ke jenjang lebih tinggi lagi yaitu jenjang SMK. Di sini saya melanjutkan sekolah saya di SMK negeri 3 Parepare, saya mengambil jurusan Teknik Komputer Dan Jaringan (TKJ). Selama tiga tahun lamanya. Setelah saya lulus dari SMK tersebut saya melanjutkan pendidikan saya di salah satu kampus yang berada di kota parepare. Yaitu kampus Institut Agama Islam (IAIN) parepare disini saya mengambil Prodi Jurnalistik Islam pada Fakultas Ushuluddin Adab dan Dakwah (FUAD). Dan saat ini saya sedang melanjutkan pendidikan saya di institut agama Islam (IAIN) Parepare. 


\section{Tradisi Mappano Masyarakat Bugis}

Masyarakat muslim di negeri ini masih terdapat beberapa kelompok yang menjadikan kepercayaan warisan nenek moyang mereka sebagai tradisi adat dan budayanya yang perlu untuk dipertahankan sebagai budaya bangsa, dan memang saat ini masih ada adat yang mereka pertahankan bahkan sudah menjadi hal-hal yang wajib dilakukan pada tiap waktu tertentu.

Namun jika ditelusuri lebih mendalam ternyata Indonesia terdiri dari beratus-ratus suku bangsa yang tiap daerahnya memiliki masing-masing adat dan tradisi yang berbeda-beda menurut daerahnya salah satunya adalah suku bugis.

Masyarakat bugis memiliki bebarapa tradisi yang masih membudaya dikalangan masyarakat awam yang masih punya kepercayaan animisme tentang hal-hal mistis dan adanya penguasa selain Tuhan, yang kepercayaan itu mungkin telah diturunkan oleh nenek moyangnya lalu diterapkan sampai saat ini. Diantara banyaknya tradisi tersebut "Mappano" atau menurunkan sesajen adalah salah satu budaya yang masih cenderung dilakukan oleh masyarakat bugis saat ini.

Pelaksanaan tradisi ini mungkin sudah dilakukan berpuluh puluh tahun lalu dan dipertahanka sampai sekarang. Namun tanpa mereka sadari sebenarnya hal ini sedikit menimbulkan konflik karena adanya sesuatu hal yang dilakukan dalam adat itu yang sedikit menyimpang dari kepercayaan agama Islam dan juga bertentangan dengan beberapa surah dan hadis, namun tak sedikit masyarakat bugis yang melupakan bahkan mungkin mengabaikan hal itu.

Pengertian tradisi "mappano" adalah salah satu adat istiadat dan kepercayaan masyarakat bugis yang telah turuntemurun dilakukan oleh suatu kelompok. Dimana masyarakat yang melaksanakannya akan berbondong-bondong untuk membawa sesajen yang berisi makanan dan biasanya diisi dengan beberapa butir telur, ayam, sokko (songkolo), dan juga buah buahan sebagai pelengkapnya. hal itu mereka lakukan dengan maksud untuk 
menghormati dan mengenang roh leluhur dan nenek moyang mereka. Mereka juga yakini bahwa apabila tidak melaksanakan hal ini maka akan ada malapetaka yang akan didapatkannya, dengan adanya tradisi "mappano" ini sebagian orang menjadikannya sebagai pencegah petaka atau pattula bala.

Ritual bugis ini merupakan tradisi yang wajib diabadikan oleh masyarakat bugis yang dalam pelaksanaannya mempunyai tata cara yang runtut, tradisi mappano memiliki beberapa tahap yaitu:

a. Tahap persiapan, tahap dimana masyarakat menyiapkan sesaji yang akan disuguhkan yang terdiri dari, sokko patanrupa, tello (telur), ota (daun sirih), jenis sokko patanrupa yaitu sokko bolong, sokko pute, sokko onnyi, sokko cella, sokko patanrupa semuanya mempunyai makna tersendiri dalam kandungan warnanya yaitu: 1) Sokko bolong (nasi ketan hitam) yang mempunyai makna sebagai tanah. 2) Sokko pute (nasi ketan putih), yang mempunyai makna sebagai air. 3) Sokko cella (nasi ketan merah), yang mempunyai makna sebagai api. 4) Sokko onnyi (nasi ketan kuning) mempunyai makna sebagai angin. Sokko ini kemudian diapitkan, sokko bolong berimpit dengan sokko, pute, serta sokko cella berimpit dengan kuning, kemudian di atas sokko yang berimpitan diletakkan tello (telur).

b. Tahap pelaksanaan, setelah tahap persiapan masyarakat kemudian memanggil dukun yang lazim disebut sanro pada masyarakat Bugis untuk memberikan mantra pada makanan tersebut atau dalam masyarakat bugis sering disebut baca doang, sanro ini akan meminta izin lebih dahulu kepada penguasa atau makhluk gaib atas tujuannya yang ingin memberikan sesaji sebagai rasa penghormatan dan penghargaan agar dalam pelaksanaan tradisi ini tidak berjalan sia sia. Setelah itu masyarakat kemudian membawa suguhannya ke sungai atau perairan yang ia percaya terdapat penguasa atau makhluk gaib dengan membuatkan sebuah wadah lopi bura' biasa juga lawasoji, kemudian menaruh makanan tersebut dan mengalirkannya.

Upacara adat ini terdiri dari prosesi pembacaan mantra dalam bahasa bugis dan konjo, kemudian diiringi tarian dari para penari dan diakhiri dengan mekarung sesajen ke sungai. 
Dari uraian pada tata cara pelaksanaan tradisi mappano merupakan ritual yang masih sering dilakukan oleh masyarakat yang terdiri dari tahap persiapan dan tahap pelaksanaan yang tata caranya dilaksanakan secara runtut oleh masyarakat bugis. Namun dalam pandangan Islam, tradisi mappano kurang sesuai dengan nilai-nilai Islam. Dengan adanya kesimpulan di atas penulis dapat menyarankan: Perlu adanya penerapan norma agama dalam masyarakat agar dalam melaksanakan tradisi tidak menimbulkan perbuatan yang kurang baik. Perlunya tingkat pendidikan yang memadai agar pola pikir masyarakat yang awam tentang kepercayaan dapat digeser menjadi pola pikir yang terarah terhindar dari perbuatan yang tidak sesuai nilai-nilai Islam. 
Biodata Penulis

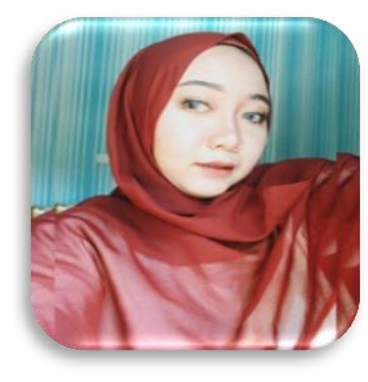

Silvi Mansyur, lahir di Paero, Pinrang, Sulawesi Selatan pada 11 Februari 1998, tepatnya 22 tahun lalu. Ia adalah anak pertama dari dua bersaudara dengan nama adik Ahmad Sukri, nama Ibu Mastini dan Nama Ayah Manyur.

Penyusun menempuh pendidikan Sekolah Dasarnya di SD 87 Tanre Assona, dan melanjutkan sekolah menengah pertamanya di SMP 2 Padakkalawa, lalu kemudian SMA di SMK Negeri 2 Pinrang dengan Jurusan Rekayasa Perangkat Lunak (RPL). Hingga sekarang penyusun menempuh masa perkuliahan di IAIN Parepare dengan Program Studi Jurnalistik Islam. Fakultas Ushuluddin, Adab dan Dakwah IAIN Parepare.

Motto :

"Ubah fikiranmu dank au dapat mengubah duniamu" 


\section{Daftar Pustaka}

Abdul Rahim, "nilai-nilai sistem perekonomian islam dalam ritual "mappadendang "'"' jurnal hukum islam, vol. 14, no. 1, juni 2016,.

Buku penetapan warisan budaya takbenda indonesia tahun 2018 diterbitkan oleh direktorat warisan dan diplpmasi budaya, direktorat jenderal kebudayaan, kementrian pendidikan dan kebudayaan.

Cinde Anjani \& Suryanto. Desember 2006. "pola penyesuaian perkawinan pada periode awal". Insan. Vol. 8, no. 3.

Djoko Widaydho, IImu Budaya Dasar, (jakarta : Pt bumi aksara, 2015)

Elly M. Setiadi.dkk. IImu budaya dasar

Hasdalia, Skripsi "kontribusi tradisi mappadendang dalam meningkatkan hubungan sosial di desa lebba'e kecamatan ajangale kabupaten bone",

Hasman B. 2011. Eksistensi musik bambu (bas) dalam kehidupan masyarakat di kecamatan malua kabupaten enrekang.fakultas seni dan desain. Universitas negeri makassar.

I Gde Pintana dan i ketutu surya diarta. Pengatntar IImu Pariwisata Juhana, Arsitektur Dalam Kehidupan Manusia (semarang: bandera, 2001)

M. Najmuddin, dkk. Pernikahan Adat Jawa Dalam Perspektif Hukum Islam Dan Hukum Positif Indonesia".

Mattulada. Manusia Dan Kebudayaan Bugis Makassar (ujung pandang: arus timur, 1972)

Muh.Aking, Mabbaca Doang: Tradisi Membaca Doa Pada Masyarakat Bugis Perantauan Di Desa Tombekuku Kecamatan Basala Kabupaten Konawe Selatan

Muhaimin Ag, Islam Dalam Bingkai Budaya Lokal: Potret Dari Cerebon, terj. Suganda (ciputat: pt. Logos wacana ilmu, 2001) 
N. Kardinah. 2009. "Keluarga dan problematikanya menuju keluarga sakinah". Jurnal ilmiah psikologi pendidikan DAN PERKEMBANGAN. Vol. I, no. 1.

Nurfadilah, skripsi "Nilai Solidaritas Sosial Dalam Tradisi Mappadendang Pada Masyarakat Paccekkeq Di Kabupaten Barru"

Puspitasari rakhmat, Jeanny Maria Fatimah, "Makna Pesan Simbolik Non Verbal Tradisi Mappadendang Di Kabupaten Pinrang"vol. 5 no. 2 juli - desember 2016, diakses 28 maret 2020.

Qadaruddin, M. (2016). Fenomenologi Akulturasi Budaya dan Agama. Rahmawati, Salah Satu Warga Kecematan Bacukiki, Yang Sering Melihat/Mengikuti Tradisi Barazanji, pada tanggal 29 maret 2020.

Rio anthony, Ma'baca-Baca, Kolaborasi Adat Dan Agama Suku Bugis, diakses dari https://www.tagar.id/mabacabaca-kolaborasiadat-dan-agama-suku-bugis

Saharia, Masyarakat Kampung Tengah, Wawancara Terkait Solusi Untuk Mempertahankan Budaya Mappatettong Bola, tanggal 30 maret 2020

Sawerigading, 'Korespondensi Bunyi Bahasa Bugis Dialek Soppeng Dan Dialek Ennak", jurnal vol. 20 no. 3, 2014

Syaiful arifin, dkk. Juni 2018. "Makna Simbolik Mappasikarawa Dalam Pernikahan Suku Bugis Di Sebatik Nunukan". Jurnal budaya. Vol.2, no. 3

Wawan saputra, Skripsi "Pesan Dakwah Dalam Tradisi Mappadendang Di Desa Kebo Kecamatan Lilirilau Kabupaten Soppeng", 


\section{Daftar Pustaka Online}

Http://repositori.uin-alauddin.ac.id/5413/1/misbahuddin.pd Https://id.scribd.com/document/427722989/skripsi-kamaruddin Http://repository.stainparepare.ac.id/786/1/14.3100.014.pdf Http://journal.ui.ac.id/index.php/jai/article/viewfile/3314/2601 Http://sulbarkita.com/acara_adat_mangngongggo_durian_warisan_le luhur_etnis_pattae_berita750.html

Https://www.academia.edu/23712372/kebudayan_upacara_rambu_s olo_tana_toraja

Https://susiangraeni28.blogspot.com/2017/05/makalah-kebudayaanrambu-solo-upacara.html?m=1

Https://www.romadecade.org/suku-toraja/\#!

Https://id.m.wkipedia.org/wiki/rambu_solo\%27

Https:// www.google.com/amp/s/docplayer.info/amp/52682107-babii-kajian-teoritis-teori-ritus-dikemukan-oleh-robertson-smitchdalam-koentjaraningrat.html

Htpps://docplayerinfo..cdn.ampproject.org//v/s/docplayer.info/kajian teoritis-teori-ritus

Http://tonenebece.blogspot.com/2016/03/rambu-solo-nilainilai.html?m=1

http://diskursusnusantara.blogspot.com/2015/11/teori-dalamcultural-studies.html

https://repository.unri.ac.id./xmlui/bitsream/handle/hartono 1997:225

Https://repository.unri.ac.id./xmlui/bitsream/handle/ soerjono 1998 Https:// www. Google. Com // siri-kehormatan-diri-dalampandangan- hamka

(cmdzirhistorian.blogspot.com/2015/09/nilai-nilai-sosil-dalamtradisi.html?m=1)

(https://researchgate.net/publication/334322828_tinjauan_hukum_is lam_terhadap_nilai_sakralitas_budaya_mappanre_temme_dal am_perkainan-adat_bugis_b0ne)

Wikipedia, dialektologi, https://id.wikipedia.org/wiki/dialektologi, pada tanggal 23 maret 2020 pukul 16.47 
Https://mojok.co/terminal/sekilas-tentang-uang-panai-aturan-adatsekaligus-ujian-bagi-masyarakat-suku-bugis-makassar https://www kompasianacom.

Https://ejournal.unsrat.ac.id/index.php/holistik/article/download/245 $92 / 24290$

Https://makassar-terkini-.id/begini-penjelasan-uang-panai-menurutagama-islam-

File://c:/users/acer/downloads/9603-22675-1-sm\%20(6).pdf Http://repository.umrah.ac.id/1584/1/jurnal\%20ravikah140569201006-fisip-2018.pdf

http://asmiatiputri.blogspot.com/2016/10/budaya-sulawesiselatan.html

http://andikiilawati.blogspot.com/2015/01/budaya-tabe-dalammasyarakat-bugis.htmi

http://andikiilawati.blogspot.com/2015/01/budaya-tabe-dalammasyarakat-bugis.html

http://diskursusnusantara.blogspot.com/2015/11/teori-dalamcultural-studies.html

https://id.wikipedia.org/wiki/mappadendang

https://ilmuseni.com/seni-pertunjukan/seni-musik/seni-musiktradisional

Http://mustazab81.blogspot/2013/06/teori-teori-teori kebudayaan.html?m=1

ttps://badikinstitute.blogspot.com/2016/03/mappettu-ada-prosesilamaran-khas-suku.html http://anassalehe.blogspot.com/2017/04/mengenal-prosesimappettu-ada-dalam.html?m=1

http://skiadabhumaniora.blogspot.com/2013/07/islam-dan-budayalokal-kajian-historis_23.html?m=1

Http://tonenebece.blogspot.com/2016/03/rambu-solo-nilainilai.html?m=1

https://arsip.simpulrakyat.co.id/2018/06/mappettuada-prosesilamaran-adat-bugis.html)

https://arsip.simpulrakyat.co.id/2018/06/mappettuada-prosesilamaran-adat-bugis.html 